
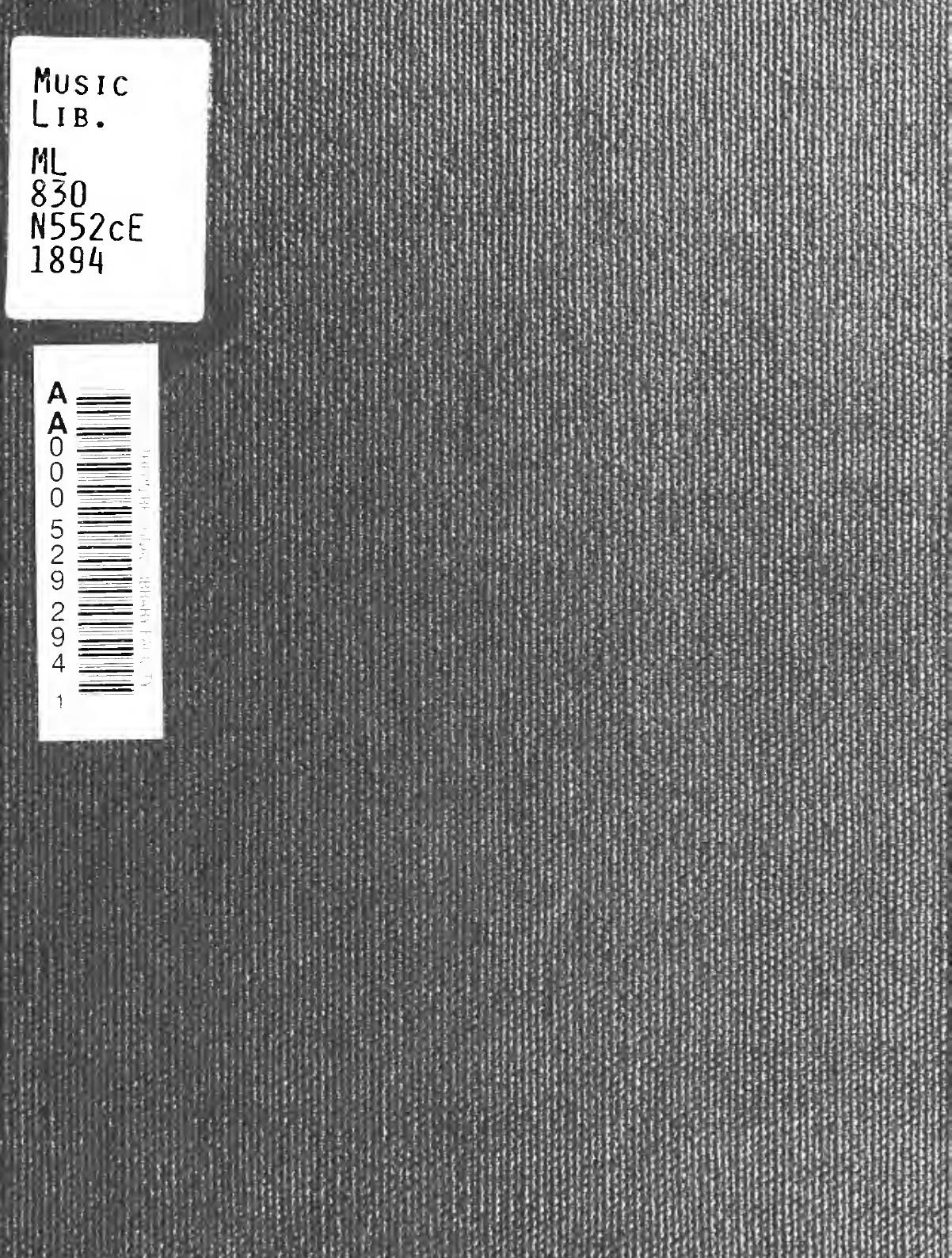

20. 3 m 2006 inoncon 16.6. Whonom (5) 20.

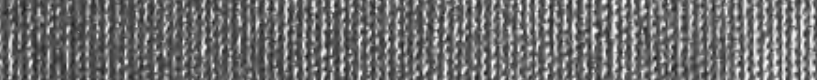




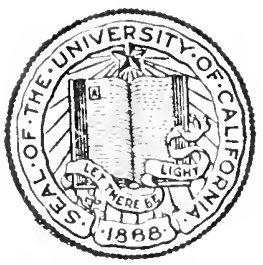

THE LIBRARY OF THE UNIVERSITY
OF CALIFORNIA
LOS ANGELES

\section{Gift of}

Mrs. Lawrence C. Lockley 

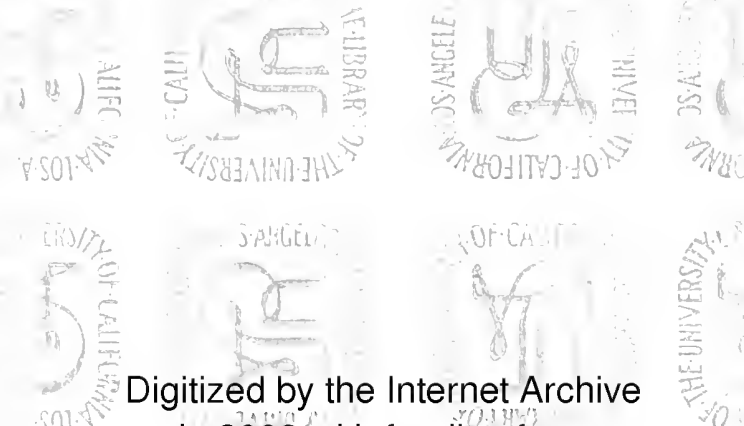
in 2008 with funding from Microsoft Corporation
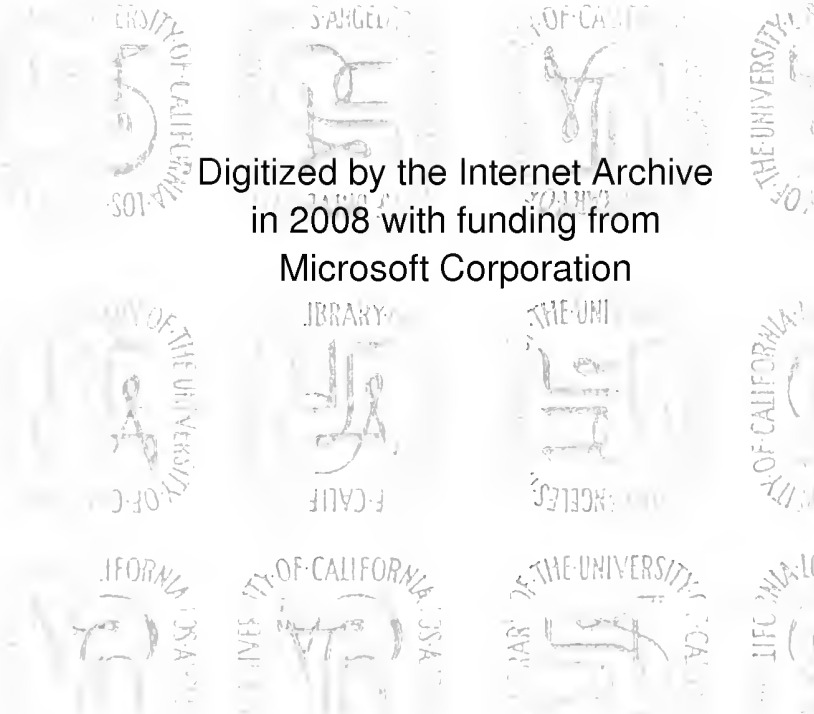





\section{CREMONA}

AN ACCOUNT'

OF THE

\section{ITALIAN VIOLIN-MAKERS AND}

\section{THEIR INSTRUMENTS}

BY

FRIEDRICH NIEDERHEITMANN

TRANSLATED FROM THE ORIGINAL, WITH NOTES AND AV APPENDIX

HY

IV. H. QUARRELL, M.A.

EXETER COLLEGE, OXFORD

"Viva fui in sylvis ; sum durâ occisa securi.

Dum vixi tacui, mortua dulce cano."

Ent. Sta. Hall.

2s $6 d$. net.

\section{Solron}

ROBERT COCKS \& CO., 6, New Burlington Street, W. Music Publishers to H.M. the Queen and II.R.H. the Prince of Wales

[AUTHOR'S P'ROPERTY]

IS94 
LONDON:

HENDERSON \& SPALDING (LIMITED), PRINTERS, 3 \& 5 , NARYLEBONE laNe, $w$. 


\section{Music \\ Library}

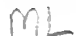

$\therefore<$

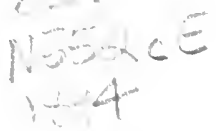

\section{CONTENTS.}

PREFACE

Introduction.-The Violin and its Origin. Gaspard Duiffopruggar. His six Violins

First PART, - The six Schools of Violin-making. The Schools of Brescia, Cremona, Naples, Florence, Venice, and the Tyrol

SECOND Part. - Development and Perfection of Violin-making. The Knowledge of the Art

ThIRd PART. - The Collector Luigi Tarisio

Fourtil Part.-Labels. Deceptions. Forgeries. Scooping

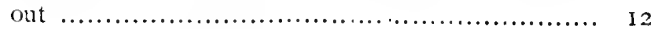

Fiftil PART. - The old Italian Varnish ....................... I4

Sixti P'ART. - Alphabetical List of the Italian Violin-makers, and a Sketch of the Lealing Features of their Work.

Conclusion

ApPExum.-Minor Makers, and Makers of Lutes, \&c. ........ 76

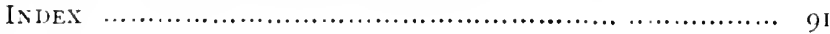





\section{AUTHOR'S PREFACE.}

Although many experts have already set forth the result of their knowledge and skill in publications of more or less merit on the subject of bowed instruments, there is still a want which it would be as desirable as praiseworthy to supply, that is, as regards the characteristic features of the Italian masters of the art of violin-making.

The Author has set himself the task of collecting, as much from the actual instruments themselves, as from ancient and modern literature, both foreign and native, the names of the masters with the greatest possible accuracy and care, and also of describing the work of each individual. $\mathrm{He}$ has omitted to dwell upon those stringed instruments which preceded the violin, and from which it may have been developed, because those materials have been sufficiently dealt with; and he begins with the origin of the violin itself, so that the reader may learn how to estimate the genuineness and the value of the Italian instruments, so far as it may be possible from the description accorded to them.

Although many instruments have passed through the Author's hands, he is still far from saying that he has seen all those which are described here. He mentions with peculiar pleasure an excellent work from which he has learnt much, and of which he has made use, and he can do this with the greater confidence because the author of that work is known to him personally as an authority of the first rank in his art. The title of this work is "The Violin : its Famous Makers and their Imitators," by George Hart. London, I875.

A large number of Italian makers are, however, not mentioned in that work, and Mr. Hart knows Gaspard 
Duiffopruggar, of Bologna, only as the famous maker of lutes, viols, and basses, but not in his original capacity as the inventor of the violin.

May the following work receive a friendly welcome from a goodly number of amateurs of true Italian instruments.

THE AUTHOR. 


\section{EDITOR'S PREFACE.}

This little work, published in $S_{77}$, appears to me to contain matter of much interest to lovers of bowed instruments, and to merit a translation into the English language. In this opinion I am fortified by the criticisms of several writers, and especially by the latest, Mr. E. Heron-Allen, in his "De Fidiculis Bibliographia," Part I., section iv., p. Ioo. Of this book he writes as follows: "This is a far more important and earnest effort of the author of the preceding work. It contains essays on the origin and history of the violin, and the six leading schools of violin-making; on Luigi Tarisio, and on labels; on varnish; and the rest of the book is taken up by an alphabetical catalogue of the Italian violin-makers and the characteristics of their work. This latter section, being the recorded observations of a really practical maker and connoisseur, renders the work of the greatest value to all violin-makers, practical or theoretical." This opinion appears to me to be carefully considered, and I cannot do better than quote it without further comment.

'To the text which I have rendered into English as exactly' as possible, preferring precision to elegance, I have appended a series of notes, which will be, I hope, of some interest to the reader. I have also added an Appendix, containing a list of minor makers, Italian by birth or by education, and also of makers of viols, lutes, cithers, and other instruments, nearly three hundred in number, with a view of providing a catalogue which may be, as nearly as possible, complete. Such a comprehensive list is not out of place in a work professing to deal with the violin, when it is remembered that the great Antonio Stradivari did not disdain to make the cetera, a fine speci- 
men by him of this instrument, of 1700 , being formerly in the possession of J. B. Vuillaume. For information valuable to the formation of this list, I have inspected some of, and have drawn upon the catalogues of, the great collections and exhibitions of musical instruments, and have also referred to, among many other authorities, the works of MII. Vidal and De Piccolellis.

I have to acknowledge my indebtedness to Messrs. W. E. Hill \& Sons, of New Bond Street, for information kindly given, and to state that I owe the confirmation of certain facts to their invaluable series of monographs on famous makers and famous instruments.

I desire to thank Mr. Georges Chanot and his son, Mr. Joseph Chanot, of Wardour Street, for information readily and courteously given.

It remains to direct the attention of the reader to the much-contested claims of Gaspard Duiffoprugcar to rank as the inventor of the violin, as treated in this book. Of these claims the Author is, with Messrs. Sandys \& Forster, Dr. Schebek, and, indirectly, Major Alexander Hajdecki, a strong advocate, differing from Messrs. Hart (to whose well-known work the Author has paid a just tribute), Vidal, and other writers of eminence.

On this question the reader should be referred to a very interesting work, recently published, “Les Luthiers Lyonnais au $16^{\text {me }}$ siècle," by Dr. Contagne.

W. H. QUARRELL.

Royal Thames Yacht Club, Albemarle Street, $I V$; and Ashby-de-la.Zouch. 


\section{INTRODUCTION.}

\section{THE VIOLIN AND ITS ORIGIN.-GASPARD DUIFFOPRUGGAR.}

Between $\left({ }^{a}\right)$ Milan and Mantua, on the banks of the Po, lies the little city of Cremona, the name of which is famous wherever the sound of a violin is heard on the face of the earth. There the masterpieces of the art of violin-making were made, which have remained unequalled for more than a hundred years, and which may be conspicuous in their perfection yet for centuries to come, and may stand out as models worthy of imitation.

It was not in Cremona, however, that the cradle of the violin was found, nor was it an Italian who invented it, but a German.

Down nearly to the middle of the sixteenth century bowed instruments were only used as an accompaniment to choirs, and then only the Viola da brazza, the Viola da gamba, and the Basso were employed; an instrument to accompany the the soprano voice was wanting. One man sought to supply this want, who, born in the Italian Tyrol, found his way, at the commencement of the sixteenth century, to Bologna, and there became a famous maker of lutes, viols, and basses. He was named Caspar Tieffenbrucker, and was called in Italian, Gaspard Duiffopruggar.

What we know about his life we owe in a great measure to the diligent researches of Dr. Edmund Schebek, of Prague, who calls him the founder of the Italian violinmaking art. He created that work of art, our violin, in such

(a) The text of the second edition of $18 S_{4}$ is similar to that of the first, from which the translation is taken.

$$
\text { I } 4 S_{4} \cdot \mathrm{A} \text {. }
$$


perfection indeed, that, although later masters may have done something to the form, nothing was left to be done to the tone-giving qualities.

When we look at this little instrument, we are astonished at the beauty of sound and expression, the fulness of tone which it can produce. It is formed of fifty-eight parts, and all these are so cunningly arranged, that an incredible amount of skill is thereby displayed, and from the melodious sound and charm which may be drawn from its weak body by a skilled hand, it has gained for itself the name of "Queen of Instruments." Although only glued together out of fragile wood, and hardly weighing seven and a half ounces, there is strained on the body of the instrument, by ingenious mechanism, a horizontal tension of eighty pounds, and a vertical strain of twenty-five pounds; and its voice will penetrate and fill the largest concert-hall and the most lofty church.

Its form is also pleasing to the eye. Everything is symmetrical, every line is beautiful, every part is in pleasing proportion to the rest. If one seeks to change anything in the outlines, or the harmonious arrangement of each individual part, this will certainly only tend to the detriment of the external appearance. In every alteration in the construction of the violin we are at best only experimenting, and we do not thereby obtain any advantage.

The interior arrangement also is not to be improved. Innumerable experiments have been made in altering the bass-bar and the sound-post, in order to obtain better tone; but every alteration of these material parts tends to injure it. Only a single alteration has proved to be satisfactory, the lengthening of the bass-bar; this was really necessary, for through the gradual rise of pitch, and through the consequent higher tension of the strings, the power of resistance of the belly could not be extended in proportion, and this had to be brought into the right proportion by lengthening the bar.

This bar is of the greatest importance. It serves not only for the strengthening of the instrument where the strain is the greatest, but particularly for the communication of the vibration, in the belly, where the lower strings make the 
slower oscillations. If the bar is too light the $\mathrm{G}$ string makes a rough sound, if it is too strong it does not give out its tone. G. Hart very appropriately compares this bass-bar with the nerrous system, and the sound-post with the heart. The smallest difference in the pcsition of both alters the Ione, and the best violin will not give forth its sound if these parts are not in their right places.

The neck of the violin is now made two centimetres longer than formerly; it concludes in a curved scroll, and the connection thus shaped cannot be better contrived, and it is not altogether without influence on the tone. As the uppermost sustaining part of the strings, it cannot be a wholly indifferent matter whether it is thick or thin, or cut from hard or soft wood.

The man who invented this masterpiece was called Gaspard Duiffopruggar $\left({ }^{b}\right)$. In I 5 Io, King Francis I. of France was carrying on war with Pope Leo X. An engagement took place near Bologna, and terms of peace were arranged in that city. On this occasion, Francis I. summoned the three most famous Italian masters to his Court, the painter, Leonardo da Vinci, Andrea del Sarto, and the luthier, Gaspard Duiffopruggar.

From the fact that many instruments by the last-named artist are adorned with finely-painted pictures in oil, and that Leonardo da Vinci was well known to be an assiduous violin-player, it may with confidence be assumed that these pictures are by the hand of that master. This supposition

(b) On this debateable and much debated point the observations of Mr. Charles Reade are interesting. Ile says that the first linown maker of the true tenor, and probably of the violin, was Ciaspard da Salo. In order of invention he puts $(1)$ the large tenor, player between the knees; (2) the violin ; (3) the small contra-bass (if not the earliest of all); (4) the violoncello; (5) the full-sized contra-lass ; (6) the small tenor. The latter part of this is doubtful, lut Mr. Reale accentuates, in the course of his arguments, one important point in particular as to tenors, namely, that the tenor is an instrument of unfixed dimensions, and can easily be reconstructed out of the early viol. As an example of this he cites the Carlino or Kerlino tenor of 1452 , exhibied at South Kensington in IS72, which has been finely copied by Mr. Georges Chanol. 
is proved to be well founded, if these pictures are compared with the painter's authentic works.

Gaspard Duiffopruggar was long known by means of a portrait etched by Pierre Vöeirot in $\left.1562{ }^{c}\right)$. In Gerber's Dictionary of Musicians, 1812 , he is also mentioned. Vidal inserts in his new work, "Les Instruments à archet," his portrait, dated I 515 , with the inscription, " 48 years old," from which he would appear to have been born in 1467 . Duiffoprugcar furnished a number of instruments for the Chapel of Francis I. of France ; of these Vuillaume, of Paris, not long ago possessed an extraordinary violoncello $\left({ }^{d}\right)$ on the back of which there was a plan of the city of Paris ; and a Parisian connoisseur has basses and viols of different kinds, also from the hand of the master. One of the last bears the inscription, "Gaspar Duiffoprugcar à la Coste Saint Sebastien à Lyon." A lute of the same period, which Dr. Schebek saw in the Convent of Neustift, is similarly marked "Gaspard Duiffoprugcar à Lyon." The master could not have borne the air of Paris, and must have gone

(c) This is the portrait reproduced by Dr. Contagne in his valuable book, "Les Luthiers Lyonnais du $16^{\text {me }}$ siècle." This interesting work contains, among much new matter, important evidence from which the author deduces the theory that Gaspard Duiffoprugcar was living as late as 1567 , or even later, to $\mathbf{1 5 7 1}$, his career commencing about 1514, and ascribing to him a son Jehan, also a luthier in Lyons. Of the handiwork of the latter nothing is known.

Dr. Contagne criticizes the author's statements incisively, and draws a conclusion differing altogether from his, and from his construction of Vidal's use of the portrait in question.

(d) This was a bass-viol. In I8I7 it belonger to M. Roquefort, and subsequently to M. Raoul ; and afterwards it was in the possession of M. Depret, an amateur 'cellist of merit.

There are also known: (I) A bass-viol, with a scroll in the shape of a horse's head, and inlaid back bearing the subject known as the "Vieillard à la chaise d'enfant." The design is attributed to Baccio Bandinelli, and the engraving to Augustin Venitien. A superb etching of the instrument by Hillemacher is in Vidal's large book. The instrument belongs to M. le Comte Louis de Waziers. (2) A small bassviol, a fine specimen, with similar carved horse's head, belonging to $M$. Chardon-Chanot, of Paris. (3) A violin in the Musée du Conservatoire in Paris.

It may be noted that M. Gallay ascribes the paintings on Duiffoprugcar's instruments to the maker himself. 
to Lyons, where he died in $153^{\circ}$. It appears, however, that his descendants worked in Italy, for there is in the possession of Prince Lobkowitz, in his castle of Eisenberg in Silesia, a lute with the inscription, "Magno Dieffoprugkar à Venetia i6i7." A family of violin-makers by name Tieffenbrucker still exists in Bavaria. $\left(^{c}\right)$

The first mention of a genuine violin by Gaspard Duiffopruggar, which is in the possession of Professor Mertz of the Brussels Conservatoire, is made by Fétis in his Biographie Universelle. This violin, which, from the description, is of a large size, dates from the year $15 \times 5 \cdot\left({ }^{\prime}\right)$ The scroll displays the head of the Court jester Triboulet, with a falling ruff. The tone is full, keen, and penetrating. Fétis is wrong, however, when he says this is the only existing violin by this celebrated maker. In the course of time five other violins by him have come to light.

I. The oldest dates from 1510 , and is to be found in the collection of F. Niederheitmann at Aix-la-Chapelle. It was made for Francis I. of France, and bears on the back the French royal crown, and under it two F's entwined, (Françots de France). The belly, sides, and peg-box show signs of rich gilding. Instead of a scroli, it has a handsomely carved

(e) The exactness of the statement that Gaspard Iuiffoprugcar's lineal descendants worked in Italy is certainly doubtful, but the theory of his Bavarian origin is confirmed by Wasielewski ami by Dr. Contagne's new evidence, which shows that he was a native of Fressin or Treising, 30 kilometres from Munich. Dr. Contagne also mentions the family of Hochbriicher of Donauwerth; the nost prominent member of this family was one who in 1720 brought out improvements in the mechanism of the harp.

From 1590 to about $\mathbf{1 6 2 0}$ there were three celebrated lute-makers of the name in Venice, Magno, Vendetino (or Wenlelin), and Leonardo. The name varies in its orthography considerably, and another authority gives the name in the lute of Prince Moritz Loblowitz as "Deffoprukhar," and the rlate I607. In a lute in the Liceo Communale th Musica al Bologna the inscription is, "Magno Vieffopruchar a Venetia I6r2." Dr. Schelek states that a viola by Vunclelino is in the Modena Museum in Vienna. The names of other members of the fanily appear in history, namely, Leopold and Ulilich (Wasiclewsi), the latler is said to have worked al bologna wilh (iaspart.

For the inscriptions in the instruments exhibited in Vienua in 1S92, see prost Apjenclix : "Tieffenbricker."

(f) This is the violin now belonging to Mr. Georges Clanot, of Wardour Strecel. 
head of a man singing. In the corners, as well as on the belly, and also on the back, is ornamental work.

The $\mathrm{F}$ holes are without much curve, and are nearly of the same width from top to bottom. It is of a broad model, and of about the ordinary length. The back is cut on the quarter, and is in two pieces: the purflings are dotble and roughly worked. The varnish is dark yellow, and thinly laid on. The instrument is easily played, and has a powerftıl, noble, and most attractive tone.

2. One of the year I5 I is in the possession of an old Aix-la-Chapelle family. It is of a similar model, but is somewhat larger and higher arched, for which reasons the tone sounds more like that of a viola. On the back, which is in one piece, and is without any grain, is a beautiful painting in oil, the Virgin Mary with the Holy Child, probably by Leonardo da Vinci. The sides have an inscription in gilt letters, and in front of the bridge is painted a count's coronet. The scroll is massive and strong, the purfling is single, the varnish rather more red and put on more thickly than in the preceding instrument.

3. One of the year $\mathrm{I}_{5} \mathrm{I}_{4}$ is in the possession of Professor Francalucci, of Bologna. $(g)$

4. Of the year $\mathrm{I}_{5} \mathrm{I}_{5}$ is the violin mentioned above, and described by Fétis as belonging to Mertz, but now in the possession of Mr. Chanot, the violin-maker, in London. The belly of this violin and that of the Niederheitmann violin, (No. I), are cut from the same plank, as may be quickly established from a comparison of the instruments, from the exact measurements of the markings in the grain, and other signs in the wood, in the most surprising manner.

$(g)$ This violin was exhibited in $\mathbf{I} S_{72}$ at South Kensington. It was pronounced on high authority, (Mr. Carl Engel), to be an excellent instrument of the earliest period. The violin numberer i 4 ) is considered by Von Wasielewski to be a larger instrument cut down. This writer ("Die Violine und ihre Meister," p. I $\$$ ) mentions, on the authority of Herr liecher, the Berlin maker, a violin considered to be a genuine instrument of the year $\mathbf{1 5 2 1}$, by Duiffoprugcar. It is interesting to notice that a lyra da braccio, "Gaspard Duiffopruggar Bononiensis anno I 5 I5," was exhibited in Vienna in I892 by Maj.-Aud. Hajdecki, of Mostar. The authenticity of, and dates attributed to, the violin above mentioned have been criticized most carefully seriatim by Dr. Contagne. 
5. Of the year I5I7. This instrument was formerly in the possession of an old musician at Aix la-Chapelle, who only played it in the orchestra at mass on Sundays in the Cathedral. This violin is especially interesting, because it bears, instead of a scroll, the portrait of Duiffopruggar himself, with his long full beard and ruff. On the lower part of the back is the picture of a city, and on the upper part an ancient bowed instrument, inlaid in various woods. The sides have the inscription, "Viva fui in sylvis, dum vixi tacui, mortua dulce cano": ("I lived once in the forest; when I lived, I was silent; now I am dead, I sing sweetly"). The same adage is inscribed under the portrait of the master etched in 1562 by Pierre Vöeirot. The back of this violin is of pear-tree, in two pieces: the varnish is dark yellow, and put on very thin.

6. The violin in the possession of Prince Nicolaus Youssoupow, $\left({ }^{h}\right)$ of St. Petersburg. From the description of the former possessor, Herr von Hunyady, of Pesth, this socalled Treasury violin bears the head of an old man instead of a scroli, the sides are adorned with gilt inscriptions, and the back with a handsome painting : it is said to be perfectly preserved, and to be of a fine model, easily played, and to have a rich and noble tone.

These violins are broad in the breast, and the curve of the middle bouts is rather flat at the corners, but little prominent. The tickets in all are alike, "Gaspard Duiffopruggar bononiensis Anno 15-"

In the quality of tone they vary one from another but little. The greatest power and beauty is to be found in No. I. Many concert violins of the first rank have been tried against it; but not one really equalled it. The archings are rather flat, and it is worthy of note that Stradivarius, in his best period, returned to the use of archings of a similarly flat design.

(h) The author of the well-known "Lutlomonographic historique et raisonnée, par un Amateur. Francfort, M. 1856 ," now a very rare l,ork: he died about a year and a half ago. 
xvi

INTRODUCIION.

The fact that the first specimen of a newly discovered instrument, in spite of all later attempts towards its improvement and perfection, thus resembled the most perfect model, and has so remained, may well be mentioned as unique of its kind. 


\section{CREMONA.}

PART I.

THE SIX SCHOOLS OF VIOLIN-MAKING.

IT gradually came to pass in the course of time that the weak and low-sounding viols were supplanted by means of the brilliant qualities of the violin, and the art of violinmaking reached its highest point in Italy. Iike a tree reaching out its branches in all directions, the art of riolinmaking spread over all the cities of Italy, and stepped over the borders into Germany, France, and even England. It may be fairly assumed that a great demand sprang up shortly after the discovery of the violin, and that violinmaking must have become a paying business, since so many turned speedily to the industry, which was often handed down in families, even unto the fourth generation. Schools sprang up, which propagated their leading principles among their scholars and through their immediate neighbourhoods. The natural consequence was a struggle to produce the best work, and from this the distinctions between the schools may be clearly marked, which may be distinguished 11 the following manner :-

(1). The Brescian School, (1520-1620), making on the foundation which Gaspard I buiffopruggar had laid, and represented through Gaspard da Salo, whose direct pupil was Maggini, and more distantly Mariani, Venturino, Isudiani, Matteo Bente, Peregrino Zanctto, sc. 
(2). The most important school follows next, that of Cremona, (I 550-1 7 66), with the Amatis, Stradivari, Guameri, Bergonzi, Guadagnini, \&c.

(3). The Neapolitan School, (I680-I S00), represented through the Milanese and Neapolitan masters. 'The families were those of Grancino, Testore, Gagliano, Landolfi, Sc.

(4). The Florentine School, (1680-1760), among whom we number also the Roman and Bologna masters, represented by the names of Gabrielli, Anselmo, Florentus. Techler, and Tononi.

(5). The Venetian School, (1690-1764), of which the most prominent masters are Domenicus, Montagnana, and Sanctus Seraphin. The first might be associated with the Cremona school, since he spent his time of apprenticeship at Cremona, and his works are conformable to those of that school.

(6). The Tyrolese School, (1640-1696), brilliantly represented by Jacobus Stainer, and the families of Klotz and Albani. If this school should not nominally belong to Italy, it at least derives its origin from that country, and its productions rank with those of Italy according to their merit. 


\section{PART II.}

\section{THE DEVELOPMENT AND PERFECTION OF VIOLIN-MAKING.-THE KNOWLEDGE OF THE ART.}

THE masters who formed the Cremona school came from Brescia; of these the Amatis, the founder of which family was Andreas Amati, took the lead. In his first independent works are to be found reminiscences of Gaspard da Salo, although it has never been proved that he was a pupil at any time of that maker. It is to be observed with most of the Italian violin-makers that they work at first in the foot steps of their master, but as soon as they gain consciousness of their own power they form their own paths to right and left, they devise new outlines and archings, and as each one prefers what he himself creates, so the various schools originate through the varying changes and differences of opinion and diversions of each master.

The style of the period has in the same way to be considered. If at the present time beauty and power conjointly are sought, and Stradivarius and Joseph Guarnerius, who possess these properties in the highest degree, are prized the most, there are also periods when preference was given to a low and soft sounding tone, and the prize was awarded to Amati and to Stainer.

At the highest period of success of the old Brescian and Cremona makers, the viohin was valued only according to its tone-producing qualities; but as the fashion began to value more and more the developing beauties of its form, the violin began to have its connoisseurs as well as its players.

Down to 1800 no master stood as high in favour as Stainer ; and in Germany, France, and England most makers 
worked upon his model. Then the Amati instruments came more into favour, and as their number in Italy was greater than the demand, they could be bought cheaper than many new instruments. The maker, William Forster, for example, bought, according to his diary, on the zoth of April, I 799, a violoncello of Nicolas Amati, together with a case and bow, for seventeen guineas, at which price the purchaser would not have parted with a violoncello of his own make. The excellence of the Italian instruments did not, however, remain long hidden, and the prices soon rose three and four fold. The spread of the Cremona instruments led to observation and comparison of their models and archings, by which the superiority of the flatter model came to be recognized. Hitherto no difference had been noted between the different Amatis; whether Andreas, Hieronymus and Antonius, or Nicolas was in question, had been overlooked in apprizing the value, but now greater attention was given to the works of Nicolas Amati, and a double price was willingly paid for a violin of the flatter model of the last named. After the taste for the flatter model had sprung up, Stradivari came more and more into honour. How blind the world had been until that time to the value of his productions is shown by the fact that Cervetto, the violoncellist, could not sell his fine Stradivari violoncello for five pounds.

The solo-players were the next who sought to obtain violins by Stradivari, and among these were Boccherini, Viotti, Rode $\left({ }^{i}\right)$, Kreutzer, Habeneck, Mazas, Lafont $\left({ }^{j}\right)$, and Baillot; and his fame now increased day by day.

Until i 820 the name of Joseph Guarnerius had not passed the frontier of the country of his birth. In that year Paganini astonished the musical world with a wonderful violin by Joseph Guarnerius del Gesì of the year I 743,

(i) The Stradivari violin owned by Rode, a very fine example of inlaid ornamental work, is in the possession of an English amateur, the happy owner of a quartet of Stradivaris. The Viotti Stradivari was in 1855 , according to Fétis, in the possession of M. Brochart de Villiers.

(j) This artist possessed also two fine violins by Giuseppe Cuamieri del Gesil; they were sold at the Goding sale in February,

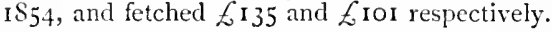


which since the death of that player on the $24^{\text {th }}$ May, I $S_{40}$, reposes in the Museum at Genoa. $\left(^{i}\right)$

A French merchant, M. Livron, had lent Paganini this violin to play one evening at a concert. When the artist had concluded and was about to return it, Livron exclaimed, "Never shall the strings be profaned which your fingers have touched ; the instrument is yours."

The names of Amati and Stradivari had become known far and wide throughout the musical world; and Paganini made the name of Guarnerius suddenly famous. Every violinist strove to possess a violin by the great Guarnerius, of whose works a goodly number were found in the Italian churches and monasteries, as well as in the hands of ignorant owners. With the appearance of numerous Guarnerius violins a great difference was seen in the models and in the technical finish, and it was recognized that the works of this master are divided into three periods, the productions of which are now classified with equal exactness with those of Stradivari. The Paganini violin is one of the large massive violins of the last period of the master.

In a similar manner the violins of Maggini became famous through the violinist Charles de Beriot. He was the first who played one of these violins in public, and the world was astonished at the penetrating power and beauty of its tone. With his popularity the price of Maggini's violins rose ; and those which had once cost 200 francs were now willingly bought at 2,000 francs. Shortly before his death De Beriot sold his own Maggini violin to Prince de Chimay for I 5,000 francs. $\left({ }^{\prime}\right)$

Then came the time when Carlo Bergonzi was recognized as a master of the first rank. In England especially his

(k) This violin was copied with great exactness by J. B. Vuillaume, and the copy presented by him to Paganini, who gave it to his pupil Camillo Sivori, in whose possession it now is.

(l) De Beriot possessed a second Maggini violin, an instrument of merit, which is now in the possession of his former pupil, Mr. H. Stcrnberg.

One of the best modern copyists of Maggini violins was (iilkes, the younger maker of that name; but few of these instruments are to be found: the varnish is cleverly imitated. 
instruments were much prized, and when once the merits of this maker had been recognized, the works of Guadagnini, Gagliano, Grancino, Sanctus Seraphin, and Montagnana came to be valued and sought after, until the whole list of Italian violin-makers became known and famous. 


\section{PART III.}

\section{THE COLLECTOR LOUIS TARISIO.}

WE are astonished, when looking back, that the spread and appreciation of the value of the Italian instruments in Germany, France, and England took place in such a short time when they had for so many centuries been disregarded. The fame of the Italian art of violin-making was, until the year I800, very small; fifty years later it had spread into every country. For this we have, for the most part, to thank one enterprising individual, who, armed with the gift of the finest observation, brought a host of the gens of Italian art to light and to the notice of the public. This was the Italian, Louis Tarisio, the son of poor parents, to whom music and musical instruments were things unknown. Tarisio was learning the trade of a carpenter, and worked assiduously, if not exactly with much liking. In his hours of leisure he amused himself with violin-playing, unnoticed, and this was destined to have much influence on his future. His first violin was an instrument of but little value. In his efforts to obtain a better instrument, the fancy awoke in him, and the foundation of his later extraordinary knowledge was thus laid. He studied all the violins which came under his notice, and observed their different characteristics critically. This passion for violins made him disgusted with his own business, and when he found that these violins were the object of a general demand he determined to turn it to account, and to follow up an apparently profitable and promising business.

With this object in view he wandered forth, provided only with slender means, and went through the cities and villages of Italy, often compelled, by hunger, to get his bread by playing on the road. His stock consisted of some 
old violins of little value. In every place, even the smallest, he knew how to ingratiate himself with the inhabitants, and to make himself welcome. In this way it became easy for him to get information about persons who owned violins. In those days there were many fine instruments in the hands of common people who had no idea of their value, and who often willingly exchanged with Tarisio a stringless example of the first rank for an ordinary instrument in playable condition. He was also wont to visit the numerous monasteries and put in order the numerous instruments which he found there $\left({ }^{m}\right)$, not only on that account, but also more for his own purposes, to increase his knowledge and to make notes of sources of profit for the future.

After Tarisio had thus acquired several good instruments, he made up his mind to travel as far as Paris. He left his best violins at home, and took with him only some of less value, with which he might inform himself as to the state of the Paris violin-market. He made his first journey on foot, carrying his violins on his back, in the year 1827 . Having arrived in the French capital, he went to the best luthier he could find, who happened to be one Aldric. Before he entered his shop, he examined his own exterior, which was hardly calculated to recommend him. His clothes were in rags, his shoes without soles, his face and hands much burned and dirty. He plucked up his courage, entered, and offered his Cremona violins to Aldric, who was at first suspicious, but became attentive enough when Tarisio produced a handsome small Nicolas Amati,

(m) The famous Gaspard da Salo contra-bass, for many years the property of Dragonetti, came from the Convent of St. Mark, Venice. At his death it passed under his will to the Churchwardens of St. Mark's, in whose custody, according to Hart, it was in I8S5. This celebrated player possessed a fine Stradivari contra-bass which he bequeathed to ihe Iunicipality of Venice, and a fine basso di camera by Domenico Montagnana, of the year 1725 or thereabouts : this passed into the possession of H.R.H. Prince Albert. His enormous three stringed contra-bass, called "the Giant," an Italian instrument of the seventeenth century, is well known to visitors to the Museum at South Kensington, to which it was presented by the late Duke of Leinster, (and see note to "Gaspard da Salo"). 
and then laid on the table five violins by Maggini, Ruggeri, and other makers.

Aldric, who concluded from the shabby appearance of the man that he did not know the value of his wares, was astonished at the high prices he asked, and only after a long bargaining and no trifling diminution of price did they come to an understanding. Tarisio went back to Italy, discontented with his first renture; he believed he had put the value of his instruments too high for the Paris market, but determined, nevertheless, upon a second attempt, intending to try his luck with other dealers. This time he took his best instruments to Paris, and visited Vuillaume, Thibout, and Chanot, who were delighted with his collection, and lost no time in buying his instruments at high prices. After this they encouraged him to bring as many instruments to Paris as he could contrive to procure. Charles Reade, who knew Tarisio well, says of him, "The man's whole soul was devoted to violins, he was a great dealer, but a greater amateur." Once when a state-equipage passed him on the boulevards, he said that he would much rather possess a Stradivari than twenty such equipages. When he had sold a masterpiece he never lost sight of it, and only waited for a favourable opportunity to get it once more into his possession.

For many years Tarisio travelled to Paris and London, and brought a great number of the finest instruments into the hands of persons who understood how to estimate their worth.

George Hart relates that Tarisio led at home the life of a hermit. Violins were his all in all. No living being dare enter his poor dwelling in the Porta Tenaglia in Milan; his nearest neighbours knew nothing of what he dicl there. He exchanged a word with no one, but went guictly on his journey's for a long time, and came as siiently back to his home. One day his neighbours saw him return thus, and then many days passed without his departure being again observed. The doors were securely fastened, and no answer was given to loud knocks. The doors of this mystcrious man were at last broken open by order of the 
authorities, and Tarisio was found dead, stretched upon a miserable bed. Everything which was about him displayed the greatest disorder. His whole furniture consisted of a table, a chair, and the bed on which he died. Violin-cases were piled in heaps, and the walls were covered with violins, backs, bellies, and scrolls. Three contra-basses hung there covered with old bags; the famous "Messie" Stradivari, $(")$ whose strings had never been touched by a bow; a dozen other Stradivari violins, $\left({ }^{\circ}\right)$ violas, and violoncellos; a contrabass by Gaspard da Salo, and nearly a hundred instruments of different masters. At last a packet of securities was found and a considerable sum in gold. Seals were placed on everything by the Court, and some nephews put in an appearance later, and established their claims as heirs.

Vuillaume of Paris soon received the news of the Tarisio's death; he hurried immediately to Milan, and succeeded in purchasing the entire collection of the dead man. $\left(^{*}\right)$

Tarisio, in his uninterrupted career of zeal, which was directed throughout by the finest judgment, had the advantage of finding instruments in their primitive condition as a

(n) The most perfect description of this violin, or perhaps of any other instrument, is contained in Messrs. W. E. Hill \& Sons' recently published monograph, "The Salabue Stradivari," rW. E. Hill \& Sons, Novello, Ewer \& Co., IS9I). The violin was purchased in 1775 from Iaolo Stradivari by Count Cozio di Salabue, whose heirs sold it in I $\$ 27$ to Tarisio.

(o) One of these was the violin dated 1736 , bearing on the label the note "d'anni 92," in the handwriting of Stradivari ; it was recently in the possession of Messrs. W. E. Hill \& Sons.

(p) For the full history of this transaction see M. Vidal's "Les Instruments à archet," and Messrs. W. E. Hill \& Sons' "The Salabue Stradivari." Vuillaume set out on the $S$ th of January, I $S_{55}$, and discovered six of the finest instruments, the Stradivari of 1736 , a magnficent (iuseppe Guarnieri, a Carlo Bergonzi, two Guadagnini, and "Le Messie," at a small farm which had belonged to Tarisio, De la Croix, near Fontaneto. He purchased the collection for So,ooo francs. The "Salabue Stradivari," otherwise called "Le Messie," remained in Vuillaume's possession until his death on the I9th of March, I875, and then passed to his dlaughters, being subsequently purchased by M. Delphin Alarch, the husband of the elder daughter. After the death of II. Alard, which happened on the 22nd of February, I8SS, the violin passed to his widow and two daughters; and after the death of Madame Alard, the violin was sold to Messrs. W. E. Hill \& Sons for $£ 2,000$, for Mr. R. Crawford, of Edinburgh, the present owner of the instrument. 
rule, and free from false inscriptions, so that he could study the characteristics of each master, without being compelled to fear that his judgment might be led astray in that manner which has so frequently occurred to others by means of the interference of other persons. 


\section{PART IV.}

\section{LABELS. DECEPTIONS. FORGERIES. SCOOPING OUT.}

IT is hardly necessary to mention that to judge an instrument by the label inserted in it is most unsafe. It is a very com. mon and a very simple trick to furnish worthless instruments with well-copied tickets bearing the names of the best makers. A forgery of this kind is generally written on ribbed paper, taken from old folios or documents, with Indian ink, to which a yellowish tinge has been given with iron rust or oxide. A scribble of this kind is then given a worn and dirty appearance, and the genuine label is ready. Another way in which a fraud often happens is through the repairers, who sometimes take genuine labels out of instruments and replace them with copies, while the real label is set forth in an instrument which is a mere copy. This is in some points so like the original that one may be easily led astray by such a trick.

A third kind of fraud which is to be found in genuine Italian instruments is generally managed in this way, by genuine or forged labels of the great masters being inserted in instruments made by their pupils or imitators, either by the latter or at a later stage by dealers. How many violoncellos of Grancino sail under the flag of Nicolas Amati! How many violins of Bergonzi and Guadagnini are valued highly as genuine Stradivari instruments! Poor Stainer comes off the worst in this respect, for nearly all the violins made by Klotz, and nearly all the high-arched violins, are usually ascribed to Stainer, just as those violins the purflings of which are made of whalebone or ebony are put down to Henry Jacobs.

It may also be observed that the old masters did not always 
use the same inscriptions and the same labels. Such variations are by no means proof of the inauthenticity of such instruments. For instance, these are genuine labels :-

(I) Gasparo di Salo fecit Bresciae Anno I6and also-

(2) Caspar Dasalo Fecit Bresciae Anno r6-

Nicolas Amati has three kinds of labels :-

(I) Nicolaus Amati Cremonen, Hieronymi filius Antonii nepos fecit Anno I6-

(2) Nicolaus Amatus Cremonen Hieronymi filius antonii nepos fecit I6-

(3) Nicholas Amatus Cremonen Hieronymi Fil. ac Antonij Nepos fecit 16-

It must also be assumed that Nicolas Amati, who attained the age of eighty-eight years, did not always use the first series of labels which he had printed. 'The labels are partly' in Latin and partly in Italian, which made the violin-makers often come into forcible conflict with orthography. Consequently, as the inscriptions in the sixth section of this book are given exactly as they are in the originals, no one but the violin-makers must be held responsible for the orthography.

At one time the opinion prevailed generally that the bellies contained too much wood, and were too thick. It was easy to remove this mistake-some wood was scooped out of the inner side and the bellies made thinner. For this system "ausschachteln" was the technical expression. The instruments now sounded more clearly, but they lost their power and fulness of tone. By the carrying out of this unfortunate idea many a splendid instrument has been ruined for ever. 


\section{PART V.}

\section{THE OLD ITALIAN VARNISH.}

Mention is now due to the Italian varnish. Here we stand before an unsolved enigma. For more than one hundred years this varnish has been lost, and all attempts to prepare a varnish which has its fire and substance have been in vain. $\left({ }^{q}\right)$ Varnish serves not only for ornament, but also as a preservative of the instrument against the effects of temperature, and for this purpose the varnish which the old masters used must have had peculiar qualities, for otherwise the old instruments, through the changes of dryness and damp, as much as by the vibration of playing, must have perished long ago.

It is certain, however, that the material which the old masters had at their command, and which was accessible to all of them, is no longer in existence, for if differences in the varnish of their instruments are noticeable, there is a resemblance in them all, in the principal ingredients, and it varies only in colour and in the thickness or thinness of the application.

One circumstance may be considered here.

This fact has been proved, that until the middle of the last century a tree was cultivated in Northern Italy which supplied an exquisite balsam, the balsam fir, Pinus balsamea. This tree died from the extraction of its resin, and on account of its timber being worthless was not re-planted and re-cultivated: and perhaps with its disappearance the

(q) Mr. Charles Reade states as his opinion that the secret of the genuine varnish had vanisheci in 1760 : and it may be pointed out that the excellent varnish used by some more modern makers, such as Enrico Ceruti, will not for a moment bear comparison with that which dates from certain earlier periods - for instance, take that of De Comble. 
solution of the enigma, and possibly of the decay of Italian riolin-making, is found.

That the varnish has an influence over the quality of tone is a fact easily proved. If a violin is played before it is varnished, and then at a later stage after the varnish has been applied, in the latter case a substantial difference in the tone will be discovered. A stiff spirit varnish makes the tone shrieking and hard, while an elastic oil or amber varnish makes it rich and soft. It would be foolish, though, to conclude from this that a badly constructed instrument, which does not in itself possess the necessary properties for good tone, may be converted into a good instrument by means of good rarnish: it may merely be asserted that the choice of wood, the construction, and varnish must harmonize, and such was certainly the case with the old masters.

Great care must be taken not to re-varnish good old instruments. Without regarding the fact that the originality and integrity thereby vanish, it changes the tone, much to the disadvantage of the instrument. Every renewed coat of varnish makes the wood of the violin thicker; it was thick enough before, but it now becomes hard, and the violin necessarily sounds worse than before, and that so much the more as the varnish is laid on harder and thicker.

It is also worth noticing that the Italian climate was highly beneficial for the purpose of drying. Oil and amber varnishes dry much more slowly in our climate; and according to the length of time that a freshly varnished instrument is exposed to dust, which will adhere to it, so the clearness and fire of the varnish are injured.

Whether an instrument with oil or spirit varnish shall be obtained is not always an easy point to decide. Some wellinformed violin-makers go too far, however, in asserting, among other things, that the Italian makers never used oil varnish, but dissolved their ingredients in spirits of wine; and opinions also differ on the point whether the colour is obtained through corrosion of the wood before the varnish is applied, or is contained in the varnish. So much is, how- 
ever, certain, that they experimented thereon quite as successfully as has been done at the present day. $\left({ }^{r}\right)$

'The colours which are given to the instruments must be sap-colours, which allow the wood to appear through them and do not cover it over. The best are dragon's blood, sandalwood, saffron, and orleans; the colouring matter is obtained by means of an infusion of spirit of wine, and a blending according to fancy is obtained by a combination of the colours. Other sap-colours are extracted by means of boiling, such as those from Kurkuma, mahogany, Pernambuco wood, \&c.

Oil varnishes are made by an extract of poppy seeds, but principally from linseed oil.

Lac varnishes or gum varnishes are made from solutions of different resins, such as amber, copal, colophonium, mastic, sandarach, elemi, or usually from oil of turpentine.

Spirit varnishes are obtained by means of dissolving hard gums, such as shellac, gum-lac, stick-lac, or benzoin, in spirit of wine.

More exact knowledge and information about the preparation of different varnishes is to be obtained from Gretschel's treatise on Violin-making, published at Weimar by Bernhardt Friedrich Voigt. $\left({ }^{s}\right)$

The Italians sometimes gave their violins before varnishing a thin coat of isinglass or of a solution of glue. Did they intend to prevent the varnish from soaking in, or did they wish to give the varnish a foundation, so as to improve its lustre? An imitation of this system in recent years has in no way proved to be of any advantage.

(r) Mr. Charles Reade says in his fourth letter on Cremona Fiddles, among other remarks, more or less (principally more) forcibly expressed :- “The Cremuna varnish is not a varnish, but two varnishes : and those varnishes always heterogeneous : that is to say, first the pores of the wood are filled, and the grain shown up by one, by two, by three, and sometimes, though rarely, by four coats of varnish, with some common gum, but clear in solution. Then upon this oil varnish, when dry, is laid a heterogeneous varnish, viz., a solution in spirit of some sovereign, high-coloured, pellucid, and, above all, tender gum. Gum-lac, which for forty years has been the mainstay of violin-makers, must never be used ; not one atom of it."

(s) For useful information on the different materials, see Appendix A in Mr. Ed. Heron-Allen's " Violin-making, as it was and is." 
While we are passing the characteristics of the different masters and their works in review, it must not be forgotten that no one instrument is exactly like another, precisely as one egg never resembles another; and more often very strongly marked differences exist between them. If this were to be denied, it would have almost to be presumed that every maker was born a master of his art. The struggle for perfection naturally involves making a new work better than the last, and a variation will be found in every improvement. 


\section{PART VI.}

ALPHABETICAL LIST OF NAMES OF THE ITALIAN VIOLIN-MAKERS, AND THE CHARACTERISTICS OF THEIR WORKS.

I. ACEVO. At first in Cremona, afterwards, r640, at Saluzzio. A pupil of Giuseppe Cappa, of the Amati school. His work is not well finished, and the wood is not well selected. $\left({ }^{t}\right)$

2. ALBANESI, Sebastianus. Cremona, I $720-1744$. Well-made instruments are rare. The model is flat, and of pleasing design. Although made at Cremona, they resemble more nearly the work of Milanese makers. The varnish especially is quite unlike that of Cremona. (")

3. ALBANI, Matthias. Botzen. Born in $162 \mathrm{I}$ at

Matthias Albani fecit Bulsani Tyrol r6-

or,

Mathias Albanus fecit in Tyrol Bolsani 16Botzen, died there in 1673 . A pupil of Stainer. His violins have higher archings than those of his master, and are of a more clumsy design. The two higher strings have a clear tone, but the lower ones are nasal. The varnish is a reddish brown.

4. ALBANI, Matthias. Botzen, I650-1709. Son of

Mathias Albani in Bulsani

Thiroli fecit anno 16the preceding, and a pupil of Nicolas Amati. His instruments are so well

(t) He is principally known by his bass-viols. Fétis mentions a viol da gamba by him, dated 1693, which had belonged to MarinNIarais. The existence of this maker under this name is not altogether clear.

(a) Vidal states he was a pupil of Carlo Bergonzi. 
made and have such a fine tone that they approach those of his master in excellence. $\left(v^{2}\right)$

5. ALBANI, Signor. Palermo, I633-1659. There is

Signor Albani in Palermo r6a good violin with this label in Brussels; besides this little of him is known.

It is possible that he is identical with one of the following makers.

6. ALBANI, Michael. The middle of the seventeenth century: he studied at Cremona, and settled afterwards at Gratz.

7. ALBANI, Paolo. Palermo, i650-i68o. A pupil of Nicolas Amati : he made good instruments, with finished workmanship, broad model, clear brown varnish.

8. ALBANI, Paul. He was living in $165^{\circ}$ in Cremona, and died there.

9. ALETZIE, Paolo. Monaco, 1720-1736. He made tenors and violoncellos principally, of which some are excellent. His varnish is hard and plain. $\left.{ }^{(w}\right)$

ıo. ALVANI. Cremona, i755. An able copyist of Joseph Guarnerius.

ir. AMATI, Andreas. Cremona, born I520, died I580. The founder of the Cremona school. It is doubtful who was his instructor. According to "Luthomonographie," he was Giovanni Marcus del Busetto, (Cremona, i $540-1580$ ), from other sources he is said to have studied at Brescia, and it is thought from a certain resemblance which his violins have with those of Gaspard di Salo that he was a pupil of

(v) The name runs Mattia, Matthias, and Mathias. He is stated to have been born at Botzen in 1621, to have worker there till about 1660 , and then to have grone to Rome. Some of his instruments have carved heards. A viola with the label, "Gio. Paolo Albani fece in Bolzano 1723 ," was exhibited in Vienna in $\mathbf{1} 892$.

(iv) Otherwise Aletzee : there appears to be some confusion alout this maker. He is also statect to have workerl for the most part at Munich, and to have been widely known by his virle damore. A maker of this name appears to have manufacturel at Munich in 17 So. A violin with a carved head, labelled "l'aulus Aletsec I fof Iamten und Geigenmacher in München 17So," was exhilhited in lienna in 1 Soz. This maker, considered to have originally worket in Italy, may have migrated to Germany : it is thought his instrmuents were copied and his labels imitated. 
that maker. The instruments of Andreas Amati are carefully finished. He used high archings, and the $\mathrm{F}$ holes are in the style of Gaspard di Salo, but the boldness of the design is wanting, and they are consequently almost too broad. The varnish is of good quality, and of a deep golden colour ; the backs are cut slab-fashion, generally of maple, but also often of pear-tree wood. The instruments are of different sizes, but generally of a small pattern, they have little power, but possess a sweet quality of tone.

Among the celebrated instruments by this maker were twenty-four violins, twelve large and twelve small, six tenors, and eight basses, which were made for the chapel of King Charles IX., at Versailles. On the backs were the arms of France, and beneath the device "Pietate et justitiâ." These instruments vanished during the Revolution, in October, I 790. $\left({ }^{x}\right)$

I2. AMATI, Antonius et Hieronymus. Sons of Andreas. Cremona, 1570-

Antonius \& Hieronymus Amati 1635 . Antonius was born Cremonen Andreae filii $\mathrm{F} \times 6-$ in 1550 , and died in 1638 . Hieronymus was probably

born in $155 \mathrm{I}$, and he died in $1635 .\left({ }^{\prime \prime}\right)$

(x) There was a violoncello bearing the arms of France and this motto in the collection of Sir William Curtis. Mr. Heron-Allen, in "Violin-making, as it was and is," describes a violin said to be of these instruments, the property of Geo. Somes, Esq. Mr. Louis Blumenberg, of New York, a violoncellist of merit, who was in London in IS9I, brought over with him a good violoncello which was reported to be one of this collection; it had recently been put in order by Silvestre, of Paris. An excellent violoncello, considered to be one of this set, was in the possession of the late Canon Bridges, and now is used by his son. It is considered that there were several other makers bearing the name of Amati whose exact connection with Andreas Amati has not come down to us. There was a Nicolas Amati at Cremona, according to some authorities, the brother of Andreas; of him little is known, he is said to have worked until the year 15 S6. There was also a Giuseppe Amati at Bologna at the beginning of the seventeenth century, according to Fétis.

(y) For the fullest information and particulars of the genealogy of the Amati family (as well as that of Guarnieri), see the Appendix to "Liutai antichi e moderni," by Giovanni de Piccolellis, (Firenze, Le Monnier, I $\$ 85$ and IS86). This information is quoted to some extent by Vidal in his " La Lutherie," (Quantin, I 889 ). 
Until the marriage of Hieronymus $\left(^{*}\right)$ the brothers worked together; they improved on their father's model, and used rather flatter archings, which caused their instruments to improve as to power. Although their names are placed together in the instruments, only few bear witness to joint workmanship, that is very different in each case, and the younger was much superior to the elder $\left({ }^{a}\right)$. Antonius did not depart much from his father's principles; he changed the $\mathrm{F}$ holes but little, and in other respects his work was extremely good.

Hieronymus, on the other hand, possessed the making of an artist to a greater extent ; he created new designs, and the $\mathrm{F}$ holes are narrower and have an elegant shape. Both brothers differ also in the form of the scroll; that of Hieronymus has more curve. The varnish is darker in the earlier instruments than in the latter-a clear orange colour; it is put on very thin, and has a brightness and a transparency which allow the pine wood, invariably used by them, to be the better displayed. Henri Wieniawsky played on a violin of this kind, of a large model. $\left(^{b}\right)$

(z) I Hieronymus Amati married, firstly, 1ppolita Zucchielli, in I 576 , by whom he had five daughters, and secondly, Laura Lazzarini, in $15 S_{4}$, by whom he had five daughters and four sons, of whom Nicolas, the greatest of the family, was the third.

(a) This differs from the opinion, probably with justice, of Félis, who says Jerome Amati was the inferior of the $t$ wo.

(b) Much remains to be written on the violas bearing the names of Antonius and Hieronymus $A$ mati. Messrs. Sanilys \& Furster describe, in their History of the Violin, p. ro6, the celebrated Radetti or Kidd instrument of $\mathrm{I} 620$. This viula came from the kadetti family of Venice into General Kidd's possession in $\mathbf{1 7 9 3}$, and was given lyy him to the father of the late Sir Frederick (iore Ouseley. From Sir Frederick Gore Ouseley it passed, aljout I860, into the hands of Mr. W. I. Adye, and then to the late Mr. Richard Blagrove. It subseruently became part of the Adam Collection, and was exhibited at South Kensington in 1872 , being ultimately sold to Mr. Ianrie, of Cilangow. Ir. Wm. Croall possesses a fine violin, by the brothers Amati, of I027, and a violoncello of 1595 , formerly the property of Kireulzer. Mr. (i. Donaldson has a curious violin of 1590 . 
13. AMATI, Nicolas. Cremona, born the $3^{\text {rd }}$ of September, 1596 , died on Nicolaus Amati, Cremonen. the I 2 th of August, I 684. $\left({ }^{c}\right)$ Hieronymi filius, Antonii $\mathrm{He}$ was the son of nepos fecit Anno I6also,

Nicolaus Amatus Cremonen

Hieronymi filius, Antonii nepos fecit $16-$ also,

Nicholas Amatus Cremonen. Hieronymi Fil. ac Antony Nepos Fecit I6Hieronymus, and by far the most noted artist of the Amati family. $\mathrm{He}$ continued for a long time to work according to his father's pattern, and made many violins of the small model. He creates the impression that he employed this first period in acquiring technical skill, and also in making experiments, for we find different examples in which he abandoned his first principles and changed his archings as well as the thickness of the wood; and in this way his new model appeared. An experienced eye can follow the gradual development until he designed his large model in I625, and made violins which are to be placed among those of the highest rank. From the purfling the arching runs at first flat and then rises suddenly nearly an inch in height, up to the middle. The edge is rounded obliquely. The corners stand forward more, and give originality to the whole. This part of the design was for long the subject of discussion, and especially with regard to its acoustic effect. The result appeared to be that these fuller corners not only look pleasing to the eye, but also rather improve than lessen the quality and power of the tone. The selection of the wood was made with great care; the wood of the bellies is of a very even and fine grain, and the wood of the backs is handsomely figured. The $\mathrm{F}$ holes have all the character of his predecessor, and are merely more boldly curved. The scroll is of a handsome design, but rather

(c) The researches of Signor de Piccolellis show that he was born on the 3 rd of December, I596, and died on the I2th of April, I684. On the $23^{\text {rd }}$ of May, I645, he married Lucrezia Pagliari, (one of the witnesses being "Messer Andrea Guarnieri"), by whom he had five sons and four daughters. 
small in comparison to the body. The golden brown varnish is very elastic, bright, and handsome. There are some violins which Nicolas Amati finished with peculiar attention and care. One of these, of the year 1680 , is in the collection of Count Cozio de Salabue at Milan, and others are those of Count Castel-barco, and of Alard and Ole Bull. (") In the last-mentioned violins the hand of his famous pupil Antonius Stradivarius is hardly to be mistaken, especially in the bold curve of the scroll, which is to be found in the later instruments of Stradivarius.

Nicolas Amati had by his wife Lucretia two sons, Hieronymus and Johannes Baptista. ( $\left.{ }^{e}\right)$ The last named, who was born on the $\mathrm{I}_{3}$ th of August, $\mathrm{I}_{57}$, deroted himself to the priesthood. Hieronymus, who was born on the 26 th of February, I649, followed his father. The immediate pupils of Nicolas Amati were, besides this son, Andreas Guarnerius, Paolo Grancino, and Antonius Stradivarius.

I 4. AMATI, Hieronymus. Cremona. Son of the last, born on the 26 th of Hieronymus Amatus Cremonen February, I649, worked Nicolai figlius fecit 16- until I696. The few instruments of his which exist are of a rather large model, but otherwise rank far below those of his father in every respect. He was the last who bore the celebrated family name in the capacity of an artist. $(f)$

(a) The Alard violin of 1645 is now in the possession of Baron Knoop, after passing through the hands of Mr. D. Laurie, of Glasgow: this is considered to be the finest specimen known. The Ole Bull violin is said to be at Bergen. The Beethoven violin is a late specimen of very doubtful date. N. Gallay states in his " Les Luthiers Italiens aux $17^{\text {me }}$ et $1 S^{\text {me }}$ Siecles," IS69, that M. Willemotte, of Anvers, possesses a Nicolas Amati with double purflings, a very remarkable specimen.

(e) This appears not quite correct, as by the researches of De Piccolellis, Nicolas Amati woulci appear to have had three other sons, Girolamo Francesco, who died an infant, Gian liattista, who also died an infant, and Giuseppe, the date of whose deatl is unknown.

(f) This maker died on the 2 rst of February, 1740. He undoultedly produced some excellent instruments, though it is considered that much of his work has gone forth to the world as that of contemporary malicrs, and the actually reliable amount of information about him is very 
15. AMBROGI, Pietro. Rome, I730. Mediocre workmanship, and similar to that of Balestrieri; the scrolls of his violins are almost similar to those of Stainer.

I6. ANSELMO, Pietro. I70I-I750. At first at Cremona, later at Florence; he worked on the model of Francesco Ruggeri, and used a handsome, reddish-yellow, soft varnish. His violoncellos are celebrated. $\left({ }^{g}\right)$

17. ASSALONE, Gaspard. Rome, about 1700. His instruments are modelled with high archings, and are of rough workmanship; he used a good yellow varnish.

I8. BAGATELLA, Antonio. (") Padua, i 782. He made violins and violoncellos of moderate merit. He adopted the method of drawing the outlines of a well-made violin on given measurements on a straight line, which, however, practically is without value.

19. BAGATELLA, Pietro. Padua, i 766 . Resembles the last, is of no importance.

20. BALESTRIERI, Thomas. Mantua, I $720-175^{\circ}$. Probably a pupil of StradiThomas Balestrieri Cremonensis vari. His model resembles Fecit Mantua. Anno I7- that of Stradivari at his latest period, but his instruments are finished more roughly. He used very different woods, but always a good wood for the bellies. His instruments are always distinguished by a powerful tone. He used two kinds of varnish, the one similar to that of Lorenzo Guadagnini, the other lighter in colour. Only violins and violas by him are known. The latter are much prized. $\left({ }^{i}\right)$

small. Mr. Charles J. Wilson possesses a very fine viola by him, of a large model, which formerly belonged to the Ries family. It bears a ticket, "Hieronymus Amatus Cremonen Nicolai figlius fecit 17o8." Violins by him are rare, one was sold in the Woolhouse Sale, December 6th, I 893 , for $£ \mathbf{I} 30$.

(g) He is said to have also worked at Venice.

(h) The author of "Regole per la construzione de violini, viole, violoncelli, e violoni," (Padua, I786).

(i) This maker's instruments vary greatly in finish, some being very rough with a darker varnish, others showing workmanship of a high quality. One of the latter order is in the possession of Miss Drysdale ; it is a violin of the year $176 \mathrm{I}$, and is an instrument of much merit, with a golden-brown varnish rather thickly applied. De Piccolellis states he worked from 1757 to 1772 . 
21. BALESTRIERI, Pietro. Cremona. 1735. His work is finished in the exterior with more accuracy, but is inferior in tone to that of the last.

22. BARBIERI. Mantua, $175^{\circ}$. He worked on the model of Stradivari. $\left({ }^{j}\right)$

23. BARZELLINI, Aegidius. Cremona, i6S. His violin model is that of

Aegidius Barzellini fecit Hieronymus Amati, with Ecolle Amatius Cremonen, r6-- golden - brown varnish. The F holes are widely cut and lie rather obliquely.

24. BELLOSIO, Anselmo. Venice, i 760. He resembled Sanctus Seraphin, but in workmanship rather than in tone. $\left(^{k}\right)$

25. BENEDICTI, Donate de. Cremona, 1674. But little known.

26. BENTE, Matteo Brescia, 1580. His instruments are of a broad angular model, and are of interest to collectors only. ( $\left.{ }^{2}\right)$

27. BERGOrZI, Francisco. Cremona, 1687. His principal merit was that he was the father of-

28. BERGONZI, Carlo. Cremona, I 7 I 2-I $750 .\left(^{m}\right) \mathrm{He}$ was a direct and the best Anno 17-, Carlo Bergonzi pupil of Stradivarius, whose fece in Cremona. influence is to be seen in all his work. He must, however, have been also an admirer of Joseph Guarnerius del Gesù, for many traces of that maker's style are to be found in Bergonzi's work. At first he adhered to the flat model and to the outlines

(j) There was also Francesco Barbieri, of Terona, 1695, of whom violns of the pattern of Andrea Guarnieri are known. (Vidal, "Ia Lutheric.")

(k) or Bellosio. IIe worked until i78o. food violoncellos of his are known. He was a pupil of Sanctus Seraptin, and the master of Marc Antonio Cerin, of Venice. Il is labe] runs, "Anselmij Busosij fecit Venetiis 17-."

(l) He is known as a maker of lutes, specimens of which instrument by him are known to exist.

(m) One form of the name is liaganzi. 
of his master, but selected $\mathrm{F}$ holes which hold a middle position between those of Stradivarius and Guarnerius. Later he altered the corners, made the lower part broader, and put the $\mathrm{F}$ holes rather deeper and nearer to the edge. From careful examination it is evident that he attained also a combination of the quality of tone of Stradivarius and of Guarnerius. The scroll is notably of bold design, and is always in harmony with the body. For his broader model Bergonzi used a broader scroll with centres much wider apart. The varnish differs greatly; it is put on sometimes thinly, sometimes thickly; often it is a rich deep red, often a pale red, and frequently a bright yellow. On the finish Bergonzi bestowed but little care, and the deep-red varnished instruments especially show striking irregularities.

Carlo Bergonzi's instruments have of late years been much sought after and have risen in price, as much on account of their great tone as for the beauty of their model and their powerful construction.

It may be mentioned that Carlo Bergonzi bought the house of Stradivarius after the death of his two sons, and that his descendants inhabited the dwelling until a recent date.

29. BERGONZI, Nicolaus. Cremona, I 750 . Son of Carlo, and his successor in Nicolaus Bergonzi Cremonensis the business. He made a faciebat ${ }_{17}-$ great number of instruments after his father's model, and used generally a hard finely marked wood. The varnish is inferior, but on the other hand his work shows much finish. The scroll has a curved form. The quality of tone is not great. $(")$

3o. BERGONZI, Michel Angelo. Cremona, r 725I 760 . The second son of

Michel' Angelo Bergonzi Figlio di Carlo fece in Cremona 1'Anno I7-
Carlo. He retained the Stradivari character in his instruments, and did good work, if nothing of a very conspicuous character.

(n) He died about $\mathbf{1 7 7 0}$, according to Vidal, but is stated by other authorities to have worked until about 1782 . 
31. BERGONZI, Zosimo. Cremona, i 760 . Very

Fatto de me $Z$ osimo Bergonzi l'anno I7- Cremona. similar to Michel Angelo. $\left(^{\circ}\right)$

32. BODIO. Venice. But little known. $(\hat{f})$

33. BONO, Gantana. Venice. Instruments of a weak character, of a third-rate order.

34. BORELLI, Andreas. Parma, $1735^{-1} 74^{1}$. Small instruments of a weak but Andreas Borelli fecit Parmae 17agreeable tone: flat archings, brown varnish, which is put on thickly on the back, and which has in many instances come off in patches. The wood used for the bellies is broad-grained and soft. (")

35. BROCHI, Carlo. Parma, i 744. Of the Nicolas Amati model, the edges flat and slightly rounded.

$3^{6 .}$ BUDIANI, Javietta. Brescia, 15 So. His instruments are often ascribed to Maggini, as they resemble them in form, and are double purfled. $\left({ }^{r}\right)$

37. BUSAN (or Busas), Domenico. Venice. Instruments of the second class; thin golden-brown varnish.

38. BUSETTO, Marcus del. Cremona, I 540-1 580 . "La Luthomonographie" mentions him as the master of Andreas Amati (?); but he appears to have lived at first at Brescia. Later he worked for several employers at Cremona, after a long, high-arched model with widely cut $F$ holes. He used two sorts of varnish, brown and deep yellow. $\left({ }^{s}\right)$

(o) The brother of Nicolaus. The subsequent mernbers of the Bergonzi family were Carlo, the third son of Michel Angelo: he worked at Cremona, making principally suitars and mandolines, and died about 1820 ; and Benedetto, who died in 1840 . The name still exists in Cremona.

(p) His name is said to have been Giambaltista : he worked about 1790.

(q) The instruments of Borelli resemble those of Gualagnini.

(r) His name has also been written Giovita Rodiani. Viclal gives the name of Francesco Budiani, a lirescian maker of lutes and viols in the fifteenth and sixteenth centuries.

(s) The same as Gian Maria Busseto, a noted maker of viols, who flourished at Cremona from I 540 to 1580. 
39. CAESTO, Pietro Antonio della. Treviso, i66o1680. A clever copyist of Stradivarius.

40. CAlCANiUS, Bernardus. Genoa, I 748. But little known. $\left(^{t}\right)$

41. CAMILE, Camillus de. Mantua, i 7 I6-I750. Small instruments with little tone, but that of a fine quality; yellow varnish.

42. CAMILLO, Darido. Cremona, I755. A copyist of Nicolas Amati.

43. CAPPA, Giachino. Saluzzio, born I590. One of his violins is marked 1640 . A small model after the style of Andreas Amati. (")

44. CAPPA, Giofreda. I590-1640. A pupil of Antonius and Hieronymus ofredus Cappa fecit
Salutiis Anno I6-Amati, at Cremona. After he had made a considerable reputation he settled at Saluzzio. Most of his instruments pass under the names of his masters, which they resemble greatly in model, colour, varnish, and tone; the difference is known only by the scroll and the $\mathrm{F}$ holes, which are more oblique and are more widely open. Cappa made a large and a small model, the former has the flatter archings and is the better of the two. His violoncellos are more valuable than his violins. $(v)$

45. CAPPA, Ofredus. Saluzzio, I640-1688. Probably

Jofredus Cappa in

Saluzzio Fecit Anno r6the son of the last, in any case his pupil : his work is not to be distinguished from that of his master.

46. CAPPA, Giuseppe. Saluzzio, I640. The little known about him is unimportant.

(t) Bernardo Calcagno is said by Vidal to have been a maker who worked with care and finish. He followed the Stradivari pattern, and used a red varnish. His label runs, "Bernardus Calcanius fecit Genure anno I 7 Io."

(u) This maker is probatly identical $w$ ith the next. Fétis, who gives I 590 as the date of his birth, states that Acevo and Sapino were his pupils.

(v) His name is also written Gioffredo. This maker appears to have worked for a time at Turin. One maker of this name is said to have worked at Saluzzio until 1725; but much confusion between the owners of the name exists. 
47. CASSINO, Antonio. Modena. But little known. $\left({ }^{*}\right)$

48. CASTELlO, Paolo. Genoa, i750. Some good violoncellos, made in the Amati style, exist.

49. CASTRO. Venice, I6S0-1720. He used good wood; the outlines are clumsy, as the corners are disproportionately long. The $\mathrm{F}$ holes are ugly. He used red varnish of poor quality.

50. CATENA. Turin, 1746 . A successful imitator of Stradivari.

51. CEliONATUS, Joannes. Turin, 1734 . Of the Amati school; yellow varnish, good workmanship. $\left({ }^{x}\right)$

52. CHRISTOPHORI, Bartholomeo. Florence, i 760. Some contrabasses and violoncellos by this master are known, which are excellent.

53. CIRCAPA, Tomasso. Naples, I730. His instruments resemble in workmanship, varnish, and value those of Alexander Gagliano.

54. CONTRERAS, Joseph. I745. He studied in Italy, and then went to Madrid, where he made a high reputation; a very handsome model and good workmanship. $\left({ }^{y}\right)$

55. COSTA, Pietro della. Treviso, I660-1700. He made good violins after the model of Stradivari. $\left(^{*}\right)$

56. DARDELLI, Padre. Mantua, i500. He made lutes as well as fine viols, of which some specimens are to

(w) Cassino, or Casini, worked from about 1665 to $\mathbf{I}_{6} \mathrm{~S}_{3}$. Violoncellos ly him are known. His label runs, "Antonius Casini fecit Muttinæ, anno 1683," or, "Antonio Casini Moden?, 1665." Ile generally used a manuscript label, in instruments of a large pattern with reddlish-brown varnish. De riccolellis gives a label of his, "Antonius Cassinus fecit Mutine, anno 17-."

$(x)$ His label is, "Joannes Franciscus Celionatus fecit Taurini, anno 1730." Another Celionati, Francesco, is said to have workel at Turin earlier in the eighteenth century.

(y) Contreras died about $\mathbf{1} 7$ So. A fine violin by him was exhibited at the Paris Exhibition of 1878 , in the collecton of l'rince CarmanChimay. His label is, "Matriti per Granadensem Josephum Contreras, anno i760." IIe had a son, whose laluel is, "Matriti per filium Granadensis Joseph, de Contreras, anno 1793."

(a) Ilis full name was P'ietro Antonio della, or dalla. Costa, lut there was a family of this name working at Cienon, lirescia, Treviso, and Venice, one of the family being namerl Agrstino. Varjous babels are in existence. 
be found in collections. As he was a monk, it is possible he may not have practised his art as a trade. $\left({ }^{a}\right)$

57. DOMINICELLI. Ferrara, I695-17 5 . Some gond basses and violoncellos by him are known.

58. DOMINICHINO, Giuseppe. Verona, I 709.

\section{Giuseppe Dominichino}

Veronensis faciebat anno I $_{7}$

59. DOMENICUS, Joannes Cesarum, r 5 10. A very old violin with this inscription

Joannes Cesarum Dominicus Romaminorum 5 ro. After the style of the older Amati violins.

is in the Niederheitmann Collection at Aix-laChapelle; it is small, has archings modelled on the design of Andreas Amati, the $\mathrm{F}$ holes are made with a similar curve, equally long and wide from top to bottom. It is made of good wood and has a handsome brown varnish. The purfling on the back runs upward and downwards in a flourish. The tone is excellent. Though nowhere any information is to be found as to this name, this instrument, which is unmistakably Italian, shows all the signs, together with its label, of great antiquity, and we are confronted by an enigma of the year mentioned, namely $\mathrm{r}_{5} \mathrm{ro}$. Can this violin be of the same period as the oldest known Duiffopruggar violin of 15 ro?

6o. DUIFFOPRUGGAR, Gaspard. Bologna, 1510-

Gaspard Duiffopruggar Bononeniensis I5- r530. The iuventor of the violin-see the Introduction. $\left(^{b}\right)$

61. DULFENN, Alexander. Livorno, 1699. His Alexander Dulfenn fecit Livorno 16 - work is but seldom to be found.

(a) Fétis mentions a famous lute, dated 1497 , made by him for the Duchess of Mantua. In ISoz this instrument was in the possession of Richard, the painter, of Lyons. The violas and violins ascribed to Dardelli are of doubtful origin.

(b) See p. xi. The label in the instrument described, belonging to Mr. Georges Channt, is in black letter type, with large bold letters. The authenticity of these printed labels, like many others, is very doubtful, to say the least. 
62. EBERTI, Tommaso. I 750 .

63. FALCO. Cremona, i $752 \cdot\left(^{\circ}\right)$

64. FARINATO, Paul. Venice, I $695^{-1} 7=5 \cdot\left({ }^{8}\right)$

65. FICKER, Joh. Christian. Cremona, I 722 . Probably a German. Although his instruments date from Cremona, they have but little in common with those of that school.

66. FICKER, Joh. Gottlob. Cremona, i 768. Son of the last ; as a violin-maker not superior to him. $\left(^{c}\right)$

67. VIORILlO, $\left({ }^{f}\right)$ Giovanni. Ferrara, 17 So. 1 cross between the style of the Tyrolean and Italian makers. The former is the more prominent, especially in the $\mathrm{F}$ holes, which are of Stainer pattern. His violoncellos have a good quality of tone.

68. FLORExUS, Florentus. Bologna, i685-17 5 .

Joannes Florentus, Quidantus

Of the Amati school. $\left({ }^{z}\right)$

fecit Bononiae anno 17 -

69. GABICELIS, Giov. Bapt. Florence, 1740. Good instruments, brown varnish, thickly put on.

70. GABRIELLI, Giovanni Baptista. Florence, I 745 . His instruments are now

Joannes Baptista de Gabrielli better known and are Florentinus Fecit $17-\quad$ valued more highly; they are carefully made. Some have a rounded model, while those of a flatter pattern possess a tone bike those of Gagliano. He used very handsome wood; the sides and backs always have a similar grain. The varnish is wanting in softness; it is yellow and

(c) De I'iccolellis states he was a copyist of lierconzi.

(d) Of the school of Santo Serafino.

(e) This maker is believed to have worked as late as ISoS.

(f) Or Fiorillo.

(s) There would seem to have been three maliers of this name, Guidantus, Antonio, and Cuidantus Giovanni. A label of the first is "Guidantus lForenus Bononice 175-." It seems certain, at any rate, that there were two makers of the name, the chler n:tmed fonnes (or Giovanni iloreno, and the younger, Guidante. (Sice fost "Guiclantus.") 
very transparent. The scroll is elegantly cut. His violas and violoncellos are superior to his violins. $\left({ }^{h}\right)$

7 I. GAETANO, Antoniazzi. Cremona, is-. Good workmanship, combined with incorrect style. The $\mathrm{F}$ holes are not in the right place.

72. GAGLlANO, Alexander. Naples, I695-r $73^{\circ}$. "La Luthomonographie"

Alexander Gaglianus Alumnus

Antonius Stradivarius fecit Neapoli Anno I7-

or,

Alessandro Gagliano Alumnus

Stradivarius fecit Neapoli

Anno $17-$ gives the following reracious narrative concerning him : Alexander Gagliano, the son of a Marquis, was at the beginning of the eighteenth century guilty of the murder of a man

who endeavoured to marry his betrothed. To escape the pursuit of justice, he left Naples, and concealed himself in a thick forest near the Borgo Marighassetto. Being well acquainted with the use of a knife, he betook himself to carving, out of ennui, and made instruments resembling violins out of the wood found in the forest, and acquired much facility in this direction. After several years he returned to Naples, and set up the workshop of a Jute-maker with the permission of the authorities, and rose thereby to much fame. According to Vuillaume, he was a direct pupil of Stradivarius, who established himself at Naples in order to secure greater scope for his art than he could ensure at Cremona. $\mathrm{He}$ appears to have acquired a profitable business at Naples, on account of which he took his sons into the business.

The instruments of Gagliano are all of a large flat model, resembling that of Stradivarius from I725 to I 730 . Although he copied his master, there are nevertheless noteworthy characteristics, by which the difference in the work of the scholar from that of the master may be recognized. The $\mathrm{F}$ holes are broader, and stand more perpendicularly.

(h) Vidal ("La Lutherie,"p. 65) gives four makers of this name, viz., Cristoforo, Bartolomeo, Gian. Battista, and Antonio. The label of Gioranni Battista, the best-known member of the family is, "Gio. Battista Gabrielli Fece in Firenze 176-." 
The scroll is mean-looking, more contracted and without curve, and is roughly worked. He did not always select the most handsome wood, and the back and sides often bear the mark of a band twisted round them. The varnish is very clear, generally yellow in different shades. $\left({ }^{i}\right)$

73. GAGLiANO, Nicolo. Son of Alexander. Naples,

\section{Nicolaus Gagliano filius Alexandri fecit $\mathrm{I}_{7}$} inclination tomards orinality. He did not work after his father's pattern, but chose a smaller one, similar to that of Stradivarius; about half-way between the Amatisé violins and those of the long pattern. Of his best period some large violins only exist. The varnish is dark, the scroll handsome, the archings moderately high, and the $\mathrm{F}$ holes widely cut. $\left({ }^{j}\right)$

74. GAGLIANO, Giuseppe. Naples, I 7 40-I $75^{\circ}$. He worked in similar fashion Giuseppe Gaglianus filius Nicolini fecit Neapoli I $_{7}$ to his father, Nicolo, and appears to have made but few instruments.

75. GAGLIANO, Ferdinando. Naples, I $740-17 \mathrm{So}$. The second son of Nicolas;

Ferdinandus Gagliano Filius Nicolai fecit Neapel 7 $_{7}$ he worked more after the pattern of Alessandro. His violoncellos are excellent. $\left({ }^{*}\right)$

(i) Another, and a more probable, account of Alessandro Gagliano's origin as a violin-maker is that he was compelled to flee from Naples on account of the result of a duel, and took refuge at Cremona, where he earned his bread by working in Stradivari's workshop. Another label of his, given by De Piccolellis, is, "Alexander Gaglianus fecit Neap. 17-" Vidal states that he died in 1725. One of the best known of his instruments is a fine violoncello, formerly in the Quinefaut Collection.

(j) Nicolo, or Nicola, Gagliano was the eldest son of Alessandro. Nany of his instruments have passed under the name of Stradivari. His workmanship is superior to that of his father. Other labels of his are known: (I) "Nicolaii Gagliano fecit in Napoli 1711" and (2) "Nicolaus ('agliano filius Alexandri fecit Neap. 17-."

(k) Ferdinando is stated to have been the eldest son of Nicolo. Two violins of his were shown at Vienna in 1592 , marked 1756 and 1762 respectively, with the label, "Ferdinantus Caliano Neapoli." 
76. GAGLIANO, Gennaro. Naples, I 700-I $75^{\circ}$. Brother of Nicolo, similar workmanship. $\left({ }^{l}\right)$

77. GAGLIANO, Januarius. Naples, i 740. He calls himself a pupil of StradiJanuarius Gaglianus Alumnus Antonii Stradivarii fecit Neapoli Ao I7varius, but, with the exception of using a large, flat model, shows little trace of his master's influence.

78. GAGLIANO, Giovanni. Naples. They come 79. GAGLIANO, Antonio. So. GAGLIANO, Raphael. down to the beginning of the present century. $(" n)$ With them the fame of the family ended. Their instruments are hardly worthy of notice.

SI. GALERZENA. Piedmont. But little known. $\left({ }^{n}\right)$

S2. GARANI, Michael Angelo. Bologna, r 685-1 720. A copyist of Stradivarius. His violas are the best of his instruments. $\left(^{\circ}\right)$

$8_{3}$. GARANI, Nicolo. Naples. He worked after the style of the Gagliano family, and was not inferior to them.

84. GATTANANI. Piedmont, $\mathrm{I}_{7} 8_{5}$. Without any especial merit.

(l) The second son of Alessandro. His label is " Gennaro Gagliano fecit Neapoli i 7-." He is generally considered to have been the best workman of the family.

(m) The second and third sons of Nicolo were Giuseppe and Antonio. They were for the most part makers of cithers and mandolines of good quality, and used a label, "Joseph \& Antonius Gagliano fecit anno ${ }_{17} 7 \mathbf{7}$ in P'latea dicta Cerriglio." Giuseppe died in 1793, and Antonio a few years later. Giovanni was the fourth son of Nicolo, and made violins of no great merit, with the label, "Joannes Gagliano nepos Januarii fecit Neapoli IS-." He died in I 806. He left two sons, Raffaele and Antonio, who worked in partnership; the former died on the 9th December, I 857 , and the latter on the 27 th June, I860. The last survivor of the family is Vincenzo, the son of Raffaele, a well-known manufacturer of strings at Naples. Vide De Piccolellis.

(n) He worked about 1790.

(o) He made some violins with rather high archings, with a good quality of tone, though no great power : he used a light-coloured varnish rather thinly put on. 
S5. GEORGI, De. Turin, $17+7$. A copyist of Stradivarius. $\left({ }^{p}\right)$

S6. GERANS, Paul. Cremona, I614.

87. GIORDANE, Alberto. Cremona, 1735. One of his violoncellos is known to be extremely good, and to have a noble tone. He used golden-brown varnish of the finest quality.

SS. GIULIANI. Cremona, i660. A pupil of Nicolas Amati, whom he copied excellently. $\left({ }^{2}\right)$

89. GOBETTI, Francisco. Venice, I690-I;20. He is sometimes also called

\section{Franciscus Gobettus}

Venetiis Fecit anno $\mathrm{I}_{7}$ Gobit. He must have been a pupil of Stradivarius; his instruments have exactly the character of the Amatisé violins of Stradivari, and bear the stamp of his genius. Many Gobit violins undoubtedly bear the label of Stradivarius with an earlier date. He surpasses the other Venetian masters, with the exception of Montagnana and perhaps of Sanctus Seraphin. The scroll is the least successful part, but everything is in harmony, and is well finished. The wood is faultless, the varnish pale red and very clear. The tone is without great power, but is round and of a noble quality. $(r)$

90. GOFRILLER, Matteo. Venice, 1700. Probably a German. There was but little Italian character in his instruments, which otherwise are well made; the varnish is poor and weak. The same remarks apply to his brother Francesco. $\left({ }^{s}\right)$

(b) Or Giorgi, Nicolo. His label is, "Nicolaus Giorgi faciebat Taurini anno 17 -"

(q) Giuliani is also known as a maker of viols.

(r) A fine violin by Gobetli was exhibited at the Paris Exhibition of ${ }^{2} 878$ by M. Wilmotte, of Anvers. His label also runs, "Franciscus Gobetti fecit Venetiis I7 I5."

(s) The name is also found Goffriller and Goffriler. The two brothers worked from about 1690 to 1740 . The label is. "Nattheus Goffriler faciebat Venetijs anno I7-" Some violoncellos of high merit with the name of Matteo are known. Ie l'iccolellis mentions two belonging respectively to the Comle Malvaria, at Bologna, and to the Narchese Ginore-Livei, at Florence. 
9I. GOUVERnARI, Antonius. Cremona, i6or. A long, elegant pattern, with Antonius Gouvernari moderately high archings. Cremonensis faciebat Anno I6- The varnish is thin, and is of an olive-yellow colour.

The tone is not great, but extremely noble and sympathetic. The $\mathrm{F}$ holes resemble those of Nicolo Amati, but are rather longer and finer, with more curve; and the scroll is very graceful, with sharp edges.

92. GRAGNANI, Antonius. Livorno, r7 So. Instru-

Antonius Gragnani fecit

Liburni Anno 17ments of the second $\operatorname{rank} \cdot\left(^{t}\right)$

93. GRANCINO, Paolo. Milan, r665-r69o. A pupil of Nicolas Amati. The family of Grancino begins with this maker, and takes much the same position with respect to Amati as that of Gagliano does to Stradivarius. His first instruments are simple copies of those of his master; he gradually takes his own path, but never really attains to an original type of instrument. He excelled especially in tenors and in violoncellos. The latter instruments surpass those of his master in volume of tone, but are inferior to them in quality. The greater number of his instruments are to be found with Amati labels. The distinction is only to be found in the scroll, which shows a different character in a somewhat lengthened form.

94. GRANCINO, Giovanni Baptista, I690-1700. At first at Milan, later at

Giov. Bapt. Grancino, filius Ferrara. His materials Paoli, fecit in Ferrara I6- are generally better chosen than are those of his father, Paolo. The model is rather flatter, and the workmanship is neat. The instruments have a powerful tone, and are generally varnished a deep yellow colour.

(t) Vidal gives the name of Gennaro Gragnani, who worked at Livorno about I730. Antonio had a son, Onorato, whose work was inferior to that of his father. Antonio Gragnani was wont to append the sign of a globe and a cross to his label. 
95. GRANCINO, Giovanni. Milan, I696-1;20. The second son of Paolo. His

Giovanni Grancino in Contrada instruments are very good, largha di Milano al Segno de la Corona $17-$ and are hardly to be distinguished from those of his brother.

96. GR INCINO, Francesco. Milan, I 7 10-1 746 . Here the same decline occurs as with the Gagliani: the Francesco Grancino figlio Giovanni fecit Mediolani $17-$ family commences with artists and ends with mechanics. (")

97. GUADAGNINI, Lorenzo. Cremona, I695-I742. The name of Guadagnini

Lorenzo Guadagnini Cremonae Alumnus Stradivarius Fecit Anno Domino 1 $_{7}$ and,

Laurentius Guadagnini fecit Cremonae $\mathbf{1} 7-$ is one of the most prominent among Italian violinmakers, and the instruments have, especially in recent years, attracted more attention, and the value has consequently increased very rapidly. Lorenzo and the two Johannes Baptista are the most noted. The first, a direct pupil of Stradivari, was considered the best; but when the merits of each are duly weighed, they will all be found to take an equal position. The instruments of Lorenzo are of a bold design; he was addicted to vary it, and changed especially the shape of the F holes considerably; sometimes inclining to those of Guarnerius, but then again returning to those of his master. The model is rather flat, with fine archings.

'The scroll is not that of Stradivarius, though it is interesting, more indeed from its originality than from its beauty. The varnish is reddish yellow, and is soft; the tone is

(u) The correct relationship of the latter members of the Cirancino family, as given by De l'iccolellis, is that Giovanni was the son of l'aolo, and that Giambattista and Francesco were his sons : he gives a lalel of the last named, "Giov. Battista and lirancesco fra. (irancino in contrada larga di Nlilano I 7-," and Vidal quotes a lalel almost similar, "Gio. e Francesco fratelli de Grancini in contrarla larga Mlilano 17-." 
powerful and of rich quality. Genuine instruments are rare, and are eagerly sought for, especially in England. $\left({ }^{v}\right)$

98. GUADAGNINI, Joannes Baptista. Milan, I 7 roI 750. At first at Piacenza.

Joannes Baptista Guadagnini The few instruments of his Placentinus fecit Mediolani 17- which are known to exist resemble those of his son.

99. GUADAGNINI, Joannes Baptista. Parma, 1750I 785 . Both of these

Joannes Baptista Guadagnini makers adhered consistfecit Parmae C S R 17- ently to the model of Stradivarius, and all their work is exactly according to his principles. They bestowed much care on the choice of wood, which is, without exception, of the finest quality. The grain of the bellies is regular and exact, and they used the finest figured maple for the backs. The varnish is of a very handsome brown colour, very clear and transparent, and put on rather thickly. The scroll is not to be distinguished from that of Stradivarius of the year 1728. The sides are high. The archings are rather flat, and are of the finest proportions. The tone is at least as noble and as powerful as that of Lorenzo. $\left({ }^{w}\right)$

ıоo. GUAI)AGNINI, Giovanni Baptista. Piacenza, I 754-I 785 . He is probably identical with the last.

Iоr. GUADAGNINI, Giuseppe. Milan, I 740-1 770. $\mathrm{He}$ appears to have worked for a short period only, and little of him is known. $\left({ }^{x}\right)$

ro2. GUADAGNINI, Giuseppe. Parma, 1760-i800. Brother of the second Joannes Baptista. Very good wood,

(v) He worked at Cremona and at Piacenza, and also at Milan; he died about 1760 . A label of his is known: "Laurentius Guadagnini Pater et alumnus Antonij Stradivari fecit Placentiz anno 17-."

(w) This maker was born at Cremona in $\mathbf{1} 7 \mathbf{1} \mathbf{1}$, and died at Turin, where he worked during the latter part of his life in 1786 . He was the son of Lorenzo. The peculiar crossed sign on some of his labels was not invariably used. His label also was, "Ioannes Baptista Guadagnini Cremonensis fecit Taurini 1776." A firm was working recently at Turin under the name of Guadagnini Brothers.

(x) This was the son of Joannes Baptista (of Milan), mentioned above, who was the brother of Lorenzo. 
the archings rather higher, the $\mathrm{F}$ holes exactly like those of Stradivarius. Good instruments. $(y)$

103. GUARNERIUS, Andreas. Cremona, I650I695. $\left({ }^{z}\right)$ The founder of

Andreas Guarnerius Cremonae his family; like Andreas sub titulo Sanctae Theresiae I6- Amati. Without his influence we should not have had the masterpieces of his nephew, Joseph del Gesì. It is the fact that in his earlier years he stood side by side with Stradivarius at the work-table of Nicolas Amati.

He worked first on the model of his master, and then changed the shape of his F holes and of the scroll; at the same time he began to use flatter archings. The varnish is not always the same, but is generally a clear orange, put on rather thickly, but wanting in transparency. The violoncellos are of two sizes, and the violins the same. The workmanship is strong, but does not display the fine execution of his master, and he used many bad pieces of wood. $\left({ }^{a}\right)$

(y) This maker is said by high authorities to have been the seconcl son of J. B. Guadagnini, of Parma and Turin. He worked at Turin, and alternately at Pavia. He had a brother, Gaetano, who worked at Turin as a repairer, and left a son, Carlo, principally known as a maker of guitars. Carlo Guadagnini had three sons, Gaetano, Giuseppe, and Felice, who were all engaged in the violin making and repairing industry : the best of them was Felice, who was working at Turin in 1835. The last, Gaetano, had a son, Antonio, born $183 \mathrm{r}$, who died in I88I. He was a maker of violins, and left two sons, Francesco and Giuseppe, who are also engaged in the business with which the family has been so long associated. (See George Hart, "The Violin.")

(z) In the archives of Cremona, thena me is Guarnieri. The Becthoven violoncello is by this maker, of 1675 .

(a) Andreas Guarnieri was born about 1625; he was the son of one Iartolommeo Guarnieri. Ile married Anna Maria Orcelli, and by her had seven children, three sons and four daughters. Ile died on the 7 th I)ecember, 1698, and was buried in the Church of San Jomenico. 
I04. GUARNERIUS, Joseph. Cremona, I6801 730. Son of Andreas. $\left({ }^{b}\right)$ Joseph Guarnerius filius Andreae His first work shows that fecit Cremonae sub titulo he was taking his own path, S. Theresiae I6varying considerably from that of his father. The breast is narrower, from which circumstance the middle bouts have an elegant outline, and the arching rises rapidly from the edge to the centre. The shape of the $\mathrm{F}$ holes shows a peculiar combination of the lines of Nicola Amati and of Andreas Guarnerius, returning to a certain extent to the pointed form of Gaspard di Salo: the F holes are also rather deeper and near to the edge, a plan in which Carlo Bergonzi followed him later on. The varnish is of the most beautiful kind, and is sometimes put on so thickly that in some places it would appear to have congealed. He made violins, tenors, and violoncellos, the last seldom and with but little accuracy, from which fact it may be assumed that he devoted more attention to the construction of the smaller instruments. The tone of all his instruments is excellent, and they attain a high value.

I05. GUARNERIUS, Pietro. Cremona and Mantua,

\begin{tabular}{|c|c|}
\hline & $1690-1728$. \\
\hline $\begin{array}{l}\text { trus Guarnerius Cremonensis } \\
\text { cit Mantuae sub tit. Sanctae }\end{array}$ & $\begin{array}{l}\text { the last. This master } \\
\text { possesses much originality. }\end{array}$ \\
\hline & In model and in workman- \\
\hline and, $:$ & ship he varies much from \\
\hline $\begin{array}{l}\text { Petro Guarnerio fecit } \\
\text { in Mantova }{ }^{7-}\end{array}$ & $\begin{array}{l}\text { his brother, and in design } \\
\text { also he differs from his } \\
\text { father, Andreas. The }\end{array}$ \\
\hline
\end{tabular}

(b) He was the third son of Andrea, and was born on the 25th of November, I666, and died about 1739. His full name was Giuseppe Giovanni. He married Barbara Franchi, by whom he had three sons and three daughters. Of the latter, the third, Anna Caterina, is said to have worked as a maker of violins with her father. H.R.H. the Duke of Edinburgh possesses an excellent violin of $16 \mathrm{~S}_{4}$ by this maker. $\mathrm{Mr}$. Charles Ould has a fine Italian violoncello which has been pronounced on high authority to be by him, but this instrument possesses characteristics of the work of Montagnana. The violoncellos of this maker are exceedingly scarce. Mr. Ould's is of the year I698. The Beethoven violin of $17 \mathrm{I} S$ is by this maker. 
breast is broader, and the $\mathrm{F}$ holes rounder and more perpendicular. The corners are more contracted and the archings higher. The scroll is broad, and the purflings finely worked, especially where they are joined in the comers. The quality and transparency of the sarnish are not to be surpassed; the colour alternates from golden to pale red. For the bellies he was fond of using a broad-grained wood, which was always regularly marked. (c)

106. GUARNERIUS. Pietro. Mantua, $1725^{-1} 7+5$. Son of Joseph filius

\section{Pietro Guarnerius fecit Cremonae Anno I7-}

Andrae. He worked more after the model of his uncle Pietro, under whom

he studied at Mantua. His work is good and is well worthy of the name of Guarnerius. The varnish is less transparent, and the scroll is executed with less curve than that of Pietro Guarnerius. $\left({ }^{\circ}\right)$

107. GUARNERIUS, Joseph Antonius del Gesù. He

Joseph Guarnerius Andreae

Nepos Cremonae IHS

and,

Joseph Guarnerius fecit

Cremonae anno 7 - IHS was born in $\mathrm{I}_{6} \mathrm{~S}_{3}$, and died in $17+5$. He was generally so called by reason of his labels bearing the sign

\section{为 \\ IHS.}

It is not known why he adopted this monogram,

(c) Pietro Giovanni Guarnieri was the ellest son of Andrea. Ile was born on the 1 Sth of February, 1665 . The date of his death is not known. Documentary evidence exists to show that in 1698 he was at Cremona. Mr. George Hart had recently in his possession a rery fine violin by this maker, dated 1707 .

(d) This was the second son of Giuseppe Giovanni, the son of Andrea. Ile was born in 1695 . This is the maker whom Fútis states to have worked at Venice from I735 to 1760 . De Piccolellis throws foubt upon the existence of this member of the family as a maker, but Viclal is positive, and cites the fine violoncello in the possession of II. L. Depret, which has " un vernis admiralle rose it fond d'or ambre," and a label, "Petrus Guarnerius filius Joseph Cremonensis fecir anno 1739 Venetiis." II also gives another lalel, of the year 1755. It may be pointed out that the statement of De l'icculellis that l'ietro the sron of Giuseppe is confused with Pietro the son of "1.orenzo," appears to be a clerical error, the name Lorenzo being written in place of Andrea. This statement appears to have puzaled Mr. J. II likening, who points out in his magazine, "The Violin," this confusion among the names. 
but it is possible that he was a nember of a religious order. The Italian craftsmen of that time were wont to combine, for social as well as for business purposes, and to give their association a religious title. For the dates of his birth and death we have to thank the researches of Vuillaume. The extract from the church register proves that Joseph Anthony Guarnerius, legitimate son of Johan Bapt. Guarnerius and Angela Maria Locadella, was born on the 8 th of June, $168_{3}$, and was baptized on the $\mathrm{I}$ Ith of the same month in the parish of San Donato, in the chapel of the cathedral. $\left({ }^{e}\right)^{3}$,

The original of this extract runs as follows :- "Guarneri (Giuseppe Antonio) figlio de' legittimi conjugi Giovanni Battista Guarneri ed Angela Locadella nacque nella parocchia di San Donato aggregata alla Cattedrale il giorno $S$ Giugno I $_{68} 3$ e batezzato il giorno i I del detto mese. Libro dei nati dal I669 al I692. G. dalla Cattedrale di Cremona, li I 9 Settembre I 355. (Signé) Fusetti Giulio Vic." $\left({ }^{f}\right)$

The father of Guarnerius does not appear to have followed the business of violin-making.

A general belief exists that Joseph Guarnerius was a pupil of Stradivarius, but strict proof of this has never been brought forward. By a comparison, however, of the instruments of the two makers, the point is established that they had really nothing in common.

If Joseph Guarnerius received his first instruction from Stradivarius, his instruments would show in some respects some resemblance; but no, not in one single point are they

(e) The date of his birth was the I6th of October, I687, (see De Piccolellis). He was the second son of Gian Battista, who was the son of Bernardo, the younger brother of Andrea Guarnieri. Gian Battista had four sons (and two daughters), of whom the famous Joseph only was a violin-maker. No entry in the annals of Cremona after 1702 concerning Joseph Guarnieri del Gesù has been found.

(f) This extract is taken from Fétis, and refers to the eldest son of Gian Battista, who clied in the same year. The real extract has been found by the later researches of De Piccolellis to be "Anno I68 sesto Die decima septima Octobris, Joseph filius D. Joannis Baptistze de Guarneris et Maria de Locadellis Juglm Baptizatus fuit p. me Joan Baptistam Barozium Prepositum. Patrinus fuit Franciscus Barozius hujus Vicinæe et obstetrix pro Revda Matre D. Clara Teodora Nicola Professa in Monasterio Sancta Marize Cistelli."-("Atti P:arocchiali di San Donato," Vol. ii., p. 83 .) 
alike: the outlines are absolutely dissimilar. The F hole of Guarnerius is long, and shows itself to be a modified form of Gaspard di Salo. The scroll can hardly differ more.

As all dates are wanting, we must endeasour to inquire by means of comparison whose pupil he really was, and by this method we come with some exactness upon Joseph, the son of Andrea, his cousin. The principles of Gaspard di Salo are clearly impressed on the works of both of them. Where Gaspard di Salo ceases to work, Joseph del Gesì begins, and produces a series of experiments, of which each one bears the stamp of genius. Fétis divides his artistic career into three periods. In the first we find instruments which differ greatly from one another in the design of the outlines and in the shape of the $\mathrm{F}$ holes; in one instance being a wonderful combination of grace and boldness, in another disfigured and careless, with the purflings roughly inlaid, as if he had no time to finish them artistically.

In the second period he gives us the most perfect specimens of violin-making, in model and in choice of the best materials, as well as in perfect workmanship. His varnish is deep golden yellow, of the greatest beauty and finest quality. The size of the instruments of this period vary to a slight extent.

In the last period, after 1740 , he made those large, massive instruments, with heavy edges, the purflings deeper inlaid, the corners grotesque, the scroll powerful and majestic, and the $\mathrm{F}$ holes somewhat more rounded.

Among such masterpieces occasionally appear some roughly made specimens, the so-called Prison violins. Guarnerius, it is said, led a very irregular life, was addicted to drink and to play, and finally found himself in prison on account of some political intrigue; and there made, with imperfect tools, instruments in rough and ready fashion, for which purpose the daughter of the gaoler was wont to secretly procure him the materials. From this arose the great difference in wood, workmanship, and varnish. (")

(g) It has been discovered that a certain (iacomo Guarnieri died in prison at Cremona on the Sth of October, 1715 : it is postible the legend is founded on this event. (Siet Ilart.) 
If the strength of the bellies is carefully tested, much irregularity is found; they are for the most part thick in the breast, but there are violins in which the belly is of the same thickness throughout, and some also (for instance, Dr. Weber's, in Berlin) in which the belly is thick at the edges and thinner at the breast. In spite of this, all have fine tone, so it is to be assumed that this master possessed a peculiar knowledge of the tone-giving qualities of wood, and that he understood how to work in his own peculiar fashion with extraordinary dexterity.

Guamerius did not in his life-time gain that fame which was his due. His great artistic power first attained its present high place of honour long after his death, and then principally through the violin used by Paganini. $\left({ }^{k}\right)$

(h) This violin is the instrument, so frequently described, which reposes in the Museum at Genoa. It is of the year I743. The magnificent violin of 1742 , formerly belonging to J. B. Vuillaume, and then to the Jate M. Delphin Alard, was presented by Madame Alard to the Paris Conservatoire in $\mathbf{I} 890$. Other celebrated violins are: (I), Mr. R. D. Hawley's, sometimes called the King Joseph, and considered the finest specimen in existence of this maker; (2) the second so-called King Joseph, which is, or was recently, in the possession of Mr. Laurie, of Glasgow ; $(j)$ the Wieniawski Joseph, of 1734 , in the possession of Mr. Wm. Croall; (4) the "Dolphin" Joseph ; (5) the violin of 1735, belonging to Edouard Remenyi. Other fine violins might be mentioned, one of the late M. Prosper Sainton, which was recently, or is now, in the hands of Messrs. W. E. Hill and Sons; while another belongs to Mr. Haddock, of Leeds, and M. Adolphe Pollitzer plays upon a fine Guarnieri violin. A splendid instrument of $I 742$ is in the possession of Signor Bazzini ; and another fine specimen, well known in musical history, is the "Violon du Ijiable" of $I 734$, so called from having been played by $\mathrm{N}$. Saint Léon in an opera of that name in Paris. The latter violin was exhibited at South Kensington in 1872 by its owner, Madame Fleury. The Plowden violin subsequently belonged to Mr. l'Egville (London), and that of Mori to Mr. Viotti Collins. Mr. J. T. Carrodus possesses two excellent specimens-one, that called the Canon Joseph, and another of I74I, which formeriy belonged to S. A. Forster, then to F. Cramer, and subsequently to a member of Dr. Nackenzie's family.

One of the finest Guarnieri violas known was formerly the property of Signor Dragonetti ; it afterwards passed into the hands of H.R.H. Prince Albert.

His violoncellos are not frequently found: it may be noticed that a fine specimen of 1730 , formerly the property of the late Jules de Swert, has recently been in the market in London. The Woolhouse violin, of 1742 , was sold, it is believed, at the recent sale for $£ 270$. 
Io8. GUIDANTUS, Joannes Florens. Bologna, 17 ;0I760. A small, high-

Joannes Florenus Guidantus arched model, long F fecit Bononiae anno 17- holes, and badly inlaid purflings. The outlines possess but little elegance, especially in the middle bouts. $\left({ }^{i}\right)$

ıо9. GUIDOMINI, Lorenz. Milan, i740. But little known.

i ro. GULETTO, Nicolas. Cremona, i790. He made strongly constructed, good instruments, after the model of Stradivari.

i i G. GUSETTO, Nicola. Cremona, i 730. His instruments have this

Nicol Gusetto Fiorentino à Cremona $17-$ peculiarity, that the outlines are not designed on the smoothly-rounded lines generally used, but in undulating fashion; and the scroll and $F$ holes the same. The arching is moderately high, the varnish yellow, and the tone powerful.

I I2. HORIL, Giacomo.

I 3 . JACOBS, Henry. Cremona and Amsterdam, 1690-I 740. He was a step-brother of the last Hieronymus Amati; and had to make his escape on account of a loveaffair with a nun, and went to Amsterdam. He copied the instruments of Nicolas Amati very skilfully, so that his instruments would generally pass for genuine Amatis, did not the eye of the connoisseur detect the distinction by the inferior varnish and the ugly scroll. He used whalebone for the purflings, and, although some German violin-makers occasionally did this also, nearly every violin which is purfled with whalebone is called a Henry Jacols. After his

(i) There is some confusion here, which has frepuently occurred elsewhere, between this name and that of liforemus, see anti. This label and description appear to belong really to the joint werk of llie two makers, Giovanni and Guidante, father and son, who lwre the name of Floreno, though Ilart quotes a label from a viola d'anore, "Joanne Guidantus, fecit bononix, ann" 1715," which was in the Exhibition at Mlilan in $\mathbf{1} 88 \mathrm{I}$. There are some violins passing tamer the name of Guidantus with a fine yellow oil ramish of rather thin quality. 
time, there was another Jacobs at Amsterdam, probably his son: who used a deep-red transparent varnish. $\left({ }^{i}\right)$

i 4. JOANNES, Andreas. Verona, r5ir. He made viols and basses.

I 5. JULIANO, Francisco. Rome, I 70I. $\left({ }^{k}\right)$

i 6. KERLINO, Giovanni. Brescia, I 449. As the initial letter of his name does not exist in the Italian language, it may be supposed that Kerlino was probably a German, or of German extraction. There was a violin in the possession of Koliker, of Paris, with the inscription, "Joan Kerlino ann : I449." Vuillaume considered this to be a converted viola, but Kerlino acquires the credit of being a violinmaker from it. $\left({ }^{l}\right)$

I 7 . KLOTZ, Egidius. Mittenwald, I660-1675. He went as a boy to Absom to learn under Stainer, and afterwards returned to Mittenwald. He worked there exactly after the Stainer pattern, and most of his violins pass for genuine Stainers. His varnish is redder, and is extremely good, if not so clear as that of his master.

i 8 . KLOTZ, Matthias. Mittenwald, i660-i 720. Son of the last. He went, having worked for a long time with his father, to Cremona and Florence. He subsequently returned to Mittenwald, and founded the industry which flourishes there to this day.

The Venetian dealers, who had been insulted and injured by Duke Sigismund, came to the conclusion to visit no longer the fair of Botzen, and selected the market of Mittenwald,

(j) This is probably meant for Pecter Jacobs, who followed the Amati model. He is sometimes ranked as a French maker, but there seems to be no special ground for such assertion.

(k) This maker worked from about 1690 to 17 Io. He has been said to be identical with one Giuliani, of rather earlier date, but this is doubtful.

(l) This is the instrument mentioned by Laborde, who saw it in 1799 ; it was in Koliker's possession in I804, when it was seen by Fétis. To Kerlino is attributed the viola, said to be of I452, an excellent instrument of much power, which was exhibited by Mr. Georges Chanot in the South Kensington Exhibition of 1872 , and which has been finely copied by hin. NIr. Charles Reade asserted that this instrument was a converted six or seven-stringed riol, nıade by Ventura Linarolli, of Venice, about 1520. 
which till then was of less importance, for their rendezrous. From this Mittenwald and its new industry, that of violinmaking, attained a more considerable fame. $A s$ in that neighbourhood agriculture was impossible and cattle-breeding unprofitable, and on that account an abundance of pine wood was easily to be obtained for violin-making, the larger number of the inhabitants were placed at the disposal of Matthias Klotz for the purposes of his business, and the most active used to travel the country with the finished goods. I ater on, dealers took up the business, and created a market for him in all parts of the world. ("

i i g. KLOTZ, Georg. Mittenwald, i 761 . Brother of the last. His instruments

Georg Klotz in Mittenwald an ner Iser $\mathbf{r}_{7-}$ are well made, but the wood is worm-eaten, by reason of its having been cut at the wrong time. The varnish is generally a dark yellow.

г 20. KLOTZ, Joseph. Mittenwald, i $7 \delta_{4}$. Similar

Joseph Klotz in Mittenwald to the last.

I2 . KLOTZ, Sebastian. Nittenwald, $1 ; 84$. His instruments are excellent,

Sebastian Klotz in Mittenwald and he shaped his archings an. 17 somewhat lower. The varnish is not always the same, and is often similar to that of Albani.

I 22. KLOTZ, Michael, of Mittenwald, and

I 23. KLOTZ, Carl, of Mittenwald, probably a grandson of Matthias. Their instruments approach those of ordinary workmanship.

124. LACASSO, Antonio Maria. Milan. But little known.

(m) The Museum of the Conservatoire in Paris possesses a viola d'amore by Matthias Klot\% of 1732 . IIt left three sons, (ieorge, Sebastian, and Egidius. There was a Johann Carl kilotz working about 1750 . 
I25. LANDOLFI, Carlo Ferdinand. Milan, I $75^{\circ}$. I 760 . As the Landolfi

Carolus Ferdinandus Landulphus violins show marked fecit Mediolani in Via St. Margaritae variations, it was supanno $\mathrm{I}_{7}-$ posed for a long time that two makers might have borne the same name, but this was not the case. Those instruments which have a bright red varnish are the best. His model is original, and the arching is similar at the edge to that of Pietro Guarnieri. Some of his instruments are carelessly finished, and without purfling, and these have one coat of varnish. His violoncellos are of a small pattern. The instruments have their value on account of their good tone. $\left({ }^{n}\right)$

I 6. LANSA, Antonio Maria. Milan, I674. He copied the Brescian masters. $\left(^{\circ}\right)$

I 27. LAUSA, Antonio Maria. Brescia, I $530-1540$. He made basses and viols; whether he also made violins is unknown.

I28. LINAROLLI, Venturi. Venice, I520. He made only basses and viols. $\left({ }^{*}\right)$

I 29. LOLIO, Joh. Bapt. Valtezze, I $75^{\circ}$. Similar to

Jo Batha Lolio di Valtezze f. anno I7-
Grancino, but without the careful selection of wood : yellow varnish. $\left({ }^{a}\right)$

I30. MAGGINI, Giovanni Paolo. Brescia, I590-I640. This famous violin-maker

Gio. Paolo Maggini in Brescia I6- followed Gaspard di Salo, and is considered to have been his pupil. His

(n) Mr. Charies Reade pronounced Landolfi to be the last maker who used the real Cremona varnish. He worked somewhat later than i 760 . De Piccolellis gives another label of his.

(o) He principally imitated Maggini.

(p) He also made lutes of various kinds. A large viol da gamba, marked "I $58_{5}$ Ventura di Francesco Linarol in Padova fecit," was shown at Vienna in IS92. Other instruments are known labelled with various labels, e.g., "Franciscus Linarolus Bergomensis Venetiis faciebat"; and a very fine tenor, labelled "Ventura di Francesco Linarol in Venetiis 1583 ," was shown in Vienna in $\mathbf{I} \$ 92$. With respect to the Author's opinion, it may be observed that violins of early form considered to be by this maker are known.

(q) This maker also worked at Bergamo. 
instruments are varnished either brown or yellow, and undoubtedly with spirit varnish. The earlier instruments have only single purfling, but later almost all have double, which is often used on the backs for ormamentation. On account of this, violins with double purflings are often erroneously called Maggini violins.

Maggini used a broad model; the archings begin to rise from the edges, the sides are rather low, the F holes have a pointed shape, and are long and characteristic. The scroll is of bold design. The violins attain a high value on account of their grand tone, and are prized as solo instruments to an extraordinary extent. De Beriot caused a great sensation with his Maggini violin; he sold it shortly before his death to Prince de Chimay for 15,000 francs. $(r)$

I31. MAGGINI, Pietro Santo. Brescia, i6zo-i6So. Son of Giovanni Paolo. His violins are well made, and have a good quality of tone, equal to those of his father; they have double purflings and similar ormamentation. His contra-basses are excellent.

(r) This country is happy in possessing a number of fine violas by Maggini. Mr. A. Hobday's, formerly in the possession of Mr. Zerbini, may be mentionel as a specimen of goud workmanship, wilh fine tone: and Mr. Emil Kreuz possesses at good specimen. Another Maggini violin, formerly the property of the lieriot, now lelongs to Mr. H. Sternberg. Some excellent copies, both in varnish and tone, of Maggini's violins were made in recent years by the younger Gilkes. Other valuable instruments are in the possestion of Caplian Warner, Sir Joseph Chitty, and Baron Erlanger, the last being lhe (ieorge III. instrument. Giovanni l'aolo Maggini was born in 1550 ; he married Iaddalena Anna looresti in I615, and died about 1632, though the exact date is unknown. They hal ten chiklien, of whom the seventh, Carlo Francesco, the only son who survived him, became a silk merchant. Evidence exists of other families of the name of Magsini at Brescia; and I'ietro Santo Magsini, the violin-maker, may have been related to Giovanni l'aolo.

For much valuable information concerning, and a critical account of, Maggini anel his work, see the valuable monograph, "(iio. lacole Magrgini, his Life and Work." (W. l\% llill d sims; Nowello, Ewer \& Co., 1S92.) In that work are given some illuntration of the line Maggini violn formerly in the lnimas Collection at lyons, and now the property of Caplain W. I'. Warner. Vieunlemps pessessed a line specimen, recently in the possession of an amalcur in 1 luscuw. 
I32. MALER, Lucas. Venice. The best lute-maker of Laux Maler his time; probably a German. He also made viols. $\left({ }^{s}\right)$

I33. MAN, Hans. Naples, I7IO-I750. But little known.

134. MANTAGAZZA. Milan, I720. An imitator of Nicolas Amati. $\left({ }^{t}\right)$

I35. MARATTI, C. B. Verona, I 700. His violins are of a small model, and are moderately good. ( ${ }^{\text {}}$ )

I36. MARIANI, Antonio. Pesaro, I568-1620. His violins have the character of Maggini, but not their value. The wood is ordinary. $\left({ }^{v}\right)$

337. MEZZABOT'TE. Brescia, r 720. He is seldom found.

I38. MEZZADIE, Alexander. Ferrara, I690-I 720. The $\mathrm{F}$ holes stand near together, and the model is inelegant. $\left({ }^{w}\right)$

J39. MILANO, Francesco. Milan, I 742. A pupil of Lorenzo Guadagnini. Stradivarius model.

ı 40. MILANO, Giuseppe Carlo. Milan, I 769.

I4. MONTADE, Gregorio. Cremona, I670-I730. Good instruments after the model of Stradivarius, whose pupil he called himself. $\left({ }^{x}\right)$

(s) He worked about 1415, and is also said to have carried on business at Bologna. This was the name discovered in two lutes found in the Castle of Eisenburg in $\mathbf{1} 872$, when the collection of Prince Lobkowitz was removed to Raudnitz. A lute by him is in the south Kensington Museum. A Sigismond Maler is said to have worked at Venice about i 526 .

( $t$ ) There were two makers of this name, Pietro and Giovanni, of whom labels are known: "Pietro Giovanni e Fratelli Mantegazza, nella Contrada di santa Marçarita in Milano al segno dell' Angelo 1770," and also one of Pietro, "Petrus, Io Fratresq. Mantegatia Mediolani in via S. Margarita anno I7So."

(u) His real name appears to have been Giambattista.

(v) His label is, "Antonio Mariani Pesaro, 16-."

(w) His label is, "Alessandro Nezadri Fece in Ferrara anno 17 I3." A Francesco Mezadri worked at Milan about 1700 to 1720.

$(x)$ He was probably a workman of Omobono Stradivari. The name appears also as Mantado and Montalde. 
I42. MONTAGNANA, Domenico. Tenice, I 700-I 750.

Domenicus Montagnana

Sub Signum Cremonæ Venetiis I $_{7}$ and,

Dominicus Montagnana in $\mathrm{Ab}$ prope Oenipontum fecit Anno $7_{7-}$

A pupil of Stradivarius. After leaving the workshop of his famous master he established himself at Cremona, from which some of his riolins are dated. Later he went to Venice, and there soon made a great reputation, as his instruments excelled those of all others in Venice. When they are observed critically, the influence of Stradivari may be observed throughout, but in the details substantial differences appear. The outlines are hard and less pleasing. The archings are flatter lengthwise, but across are more expanded. The $\mathrm{F}$ holes incline to the design of Joseph Guarnerius. The scroll is large and boldly curved.

The varnish of Montagnana excites the admiration of all connoisseurs; it is golden brown and of velvet-like appearance, fuil of life and fire. He made violins, violas, and violoncellos, the violins in two sizes. $(y)$

In the latter years of his life he retired to the Tyrol. I 43. MONTEGRATIA, Pietrus Johannes. Milan, 17 So. Workmanship in the style of J. Bapt. Guadagnini, with a handsome model and careful execution. His violas are valued more highly than his violins.

I44. MORELLA, Morglata. Venice, I550. His

Morglata Morella fece in Venetia I $_{5}$ 45. NOVELLO, Marco Antonio. Venice; and

If6. NOVELlo, Pietro Valentmo. Venice. They violins by him are knolins by hin are

violas are famous. No 
lived at the commencement of the eighteenth century, and had in their time a considerable reputation.

147. OBIZI, Bartolomeo. Verona, I 750. He worked after the style of Maggini, but on a somewhat narrower model. $\left({ }^{a}\right)$

I 48. OBUE, Bartolomeo. Verona, i 755. But little known.

I 49. ODOARDI, Giuseppe. A peasant. He made, as an amateur, several excellent violins. He died at the age of twenty-eight years. $\left({ }^{b}\right)$

I50. PALMA, Paulus. Lucca, I760. A small model, similar pattern to that of Nicolas Amati.

I5 I. PANORMO, Vincenzo. He was born in Palermo in 1740 , and died there in

Vincenzo Panormo

di Palermo. Fecit Anno 17I 8 I 3. He was one of the best of the imitators of Stradivari. He lived for a short time in Paris, where some of his instruments are dated, and went afterwards to England and Ireland. In Dublin he found an old billiard-table of maple, which he used for his backs. He was not choice about his materials, but among his many instruments of decided mediocrity there are some of a high order. The $\mathrm{F}$ holes are very beautifully cut, but the scroll is of varying character. $\mathrm{He}$ made violins and contra-basses. ${ }^{c}$ )

I52. PANSANI, Antonio. Rome, I 7 So-I 785. He is seldom met with. $\left({ }^{d}\right)$

(a) Or Obici. His label is, "Bartolamio Obici in Verona 1684."

(b) He worked at Ascoli in 1673.

(c) He is said to have been born at Monreale, near Palermo, on the 3oth November, I 734. His labels are, "Vincenzo Panormo me fece Marsiglia, I 760, Sicily," and "Vincenzo Panormo, Londra, I 79I"; and his Paris labels are, "Vincent Panormo, rue de l'Arbre Sec, Paris, 17-," and "Vincenzo Triusano Panormo, fecit Parisiis, Anno 17-." There is much uncertainty about the dates, and it is suggested that one of his sons was working in London during the latter part of his father's residence in Paris. He left several sons, Joseph (whose son, Edward Ferdinand, the guitar-maker, died at Brighton on November 3rd, I891), Georges Louis, the bow-maker, and Edouard Vincenzo. Panormo is considered by De Piccolellis to have perhaps been a pupil of Bergonzi.

(d) He is said to have worked also at Venice; the name also appears as Panzani. 
I53. PASTA, Domenico. Brescia. I7I0-1730; and

154. PASTA, Gaetano. Brescia, 1710. Both these made flat-modelled instruments, which have very good tone. $\left({ }^{c}\right)$

I55. PAZZINI, Giovanni Gaettana. Florence, i640. i rough, high-arched

Giovanni Gaettana Pazzini model, clearly grained. Florentinus anno 16- good toned wood, dark brown varnish. (")

I56. PFRETSCHNER, Carl Friedrich. Cremona, $79+$; and

I57. PFRETSCHNER, Johann Gottlob. Cremona, I794. Immigrants from Bararia; both made instruments after the model of Stradivarius, of moderate merit.

i5s. PICINO. Padua, riız. A high model, dark varnish.

I59. POLLUSKA, Antonio. Rome, I75I. But little known. $\left({ }^{r}\right)$

ı60. POZZURNUS, David. Genoa, I762. His instruments are seldom found. $\left({ }^{h}\right)$

I6r. RACCERIS. Mantua, i670. He appears to have been associated with one of the Gaglianos.

I62. RAPHAEL, Neila. Brescia, 1652, He made good violins and violas of

Nella Raphael

Brescia A. I6- a model similar to that of Maggini. He ornamented the backs and sides with inscriptions and designs. His varnish is dark yellowish brown, thinly laid on. The tone is not powerful, as the bellies are rather weak; on the other hand they have an agreeable tone which is easily produced.

(e) The name of Antonio Pasta, 1710-i 730, is also found.

(f) De I'iccolellis considers him to have been a pupil of Maggini, but this is not certain ; he cites a label in evidence, "tian (iactano Pazzini allievo dell' Maggini di Brixix Fecit anmo 1660." Very little is known about this maker.

(s) Or Pollusca.

(h) Or Davide J'izzurmus. 
I63. REGGIERI. Cremora. Not to be confounded with Ruggeri. He copied Joseph Guarnerius.

r64. RENISTO. Cremona, I $73^{8}$. According to his label, he was a pupil of

Renisto Cremonae Alumnus

Carlo Bergonzi fecit 17-Carlo Bergonzi, but it cannot be said this may be distinguished in his instruments. They resemble far more those of Francesco Ruggeri. The model is high, the wood ordinary, the varnish is good. He made a large number of violins of a small pattern.

165. ROGIERI, Domenico. Cremona, i 7-. Good

Domenico Rogieri fecit in Cremona 17 - instruments after the style of Nicolas Amati. Dark brown varnish. $\left({ }^{i}\right)$

I66. ROVELLI. Cremona, I 744. He is little known.

I67. RUDGER. Cremona, 1650-1;00. This master has often been considered to be a member of the Ruggeri family, but has really no connection with it. His violins and violas are especially good. The violoncellos are large and broad, with the middle bouts much hollowed out. The varnish is dark brown, and is of good quality.

I68. RUGER, Francesco. Cremona, I640-1684. $\left({ }^{j}\right)$ His instruments have pro-

Francesco Ruger, detto il Per in Cremona dell' Anno I6-

RUGCERI, Francesco. Cremona, i668

I69. RUGGERI, Francesco. Cremona, I668-I $720 .\left({ }^{i}\right)$ The family of Ruggeri

Francesco Ruggeri dett' il Per in Cremona l'anno I6that of Amati, for a long time a prominent position

(i) This maker may have been one of the family of Rogeri, or Rogieri, who came from Brescia. (See below, No. 173.) A good deal of confusion has occurred between the families of Rogieri and Rugieri.

(j) Vidal gives a label of this maker, of $\mathbf{I} 686$.

(k) There is much doult as to the exact relationship of the members of the family of Ruggeri or Rugieri, and the separate iclentity of this maker from that of the preceding, and the dates of his career, are not clearly ascertained. Mir. Sydney Brooks has a good violoncello of I 693 by this maker. 
in Cremona, and was in artistic achievements but little inferior to it. The work of Francesco belongs to the school of Amati, without being absolute copies. The design of the outlines and archings is elegant, and the F holes come in from midway between those of Nicholas Amati and of Stradivarius. The scroll is gracefully carved, and harmonizes exactly with the body. The varnish is clear red, approaching golden, not to be surpassed, and is perhaps unequalled. The back is thickly, and the belly thinly, rarnished. He made violins, violas, and violoncellos, the tone of which is extremely clear and intense.

I $; 0$. RUGGERI, Giacinto. Cremona, I696. The few instruments of his

Giacinto, figlio di Francesco Ruggero detto il per 16 which exist bear clearly the stamp of his father Francesco, in whose work-

shop he was undoubtedly trained. (")

I7I. RUGGERI, Giovanni Baptista. I666-I725. ("') A pupil of Nicolas Amati :

Io: Bapt. Rogerius Bon: Nicolai Amati Cremona alumnus Brixiæ fecit Anno Domini $17-$ he established himself first at Cremona and afterwards at Brescia. $\mathrm{He}$ varies materially from the model of Francesco, uses higher archings, and makes the $\mathrm{F}$ holes less elegant and the scroll

(l) Mr. G. I. Foster Cooke has a violoncello by this maker, Giacinto (the son of Francesco), whose instruments are somewhat rare. The back and sides are of pear-wood, the lack being in one pices. The varnish is of a fine dark colour. The shape is of the bold broad type found in the instruments of the Rugieri family. The tone of the upper strings is sweet in quality, and that of the lower possesses great depth and richness. The ticket, as kindly furnished by the owner, is, "Ciiacinto filio di Francesco kuggeri detto II Per I696." This violoncello was formerly the solo instrument of Mr. Hancock, the favourite pupilof Lindley.

(m) There is some confusion here in order and in orthograplay. This master was a maker of Brescia, one of the Rogeri family and the father of Pietro Giacomo Rogeri, or Rogieri. The l'rescian and Cremonese families are here not clearly distinguished ; this, consitering the many varicties of spelling, is not to be wontered at. De l'iccoletlis has done much to clear up the confusion. To this maker is due sirnor l'iatti's fine violoncello, which formerly letonged to the buc de Lilla, and once to Paganini. 
more clumsy. His instruments possess excellent qualities, and are valued almost as highly as those of Francesco.

I 72. RUGGERI, Vincenzio. Cremona, I695-1730.

Vincenzo Ruger detto il Per

In Cremona I6-
Of similar character but inferior to the work of Francesco. $\left({ }^{n}\right)$

I73. RUGGERI, Pietro Giacomo. Brescia, I 700-I 720.

Petrus Jacobus Ruggerius de

Nicholay Amati Cremonensis fecit Brixiae I7-

The pattern is narrower than that of the preceding maker, the scroll insignificant, the $\mathrm{F}$ holes similar to those of Francesco. The varnish is of very beautiful quality. The violoncello of Signor Piatti is by this master, of the year $17 \mathrm{I} 7 .\left(^{\circ}\right)$

174. RUGGERI, Guido. Cremona. But little known.

I75. SALO, Gaspard di. Brescia, I550-I6r2. His birthplace is the little town

Gaspard di Salo in Brescia I6also, of Salo, on the lake of Garda. He made on Gasparo da Salo fecit Bresciae $A^{\circ}$ the foundations laid by also, Gaspard Duiffopruggar, Casper Dasalo Fecit Bresciae $\mathrm{A}^{\circ}$ and varied but little from his model. The middle bouts are cut as flat, and the corners are less prominent, the $F$ holes longer, running more parallel, and wider open, and the archings are rather higher. For the bellies he always used pine with a perfect regularity of grain. As the violin in his time was a new instrument then but little introduced, it is natural that basses, violoncellos, and viols of Gaspard di Salo are to be found in greater number than violins.

It is worthy of note that he, as did later his successors

(n) Vincenzo Rugieri made more violoncellos, apparently, than violins. The Beethoven viola is by Vincenzo Rugieri, but the date is doubtful.

(o) This maker was the son of Giovanni Battista Rogeri (I7I). Another label is known, "Petrus Jacobus Rogeri fecit Brixiæe I7-." The violoncello mentioned above, a very fine instrument, is now in the possession of an English amateur; it is the instrument which was once owned by Paganini, and bears his initials, N. P., carved ly him. 
Amati and Stradivarius, at first made high-arched violins, and in the course of time shaped his archings on a lower model.

For the backs and sides of the larger instruments he generally used pear-tree wood, for the violins only maple. The technical finishing in all his instruments is not partict. larly good, according to modern ideas; the purfling is not so polished and neat, as the later makers knew how to finish it. His greatest merit is his fulness of tone, which is extremely great.

Gaspard di Salo's instruments are in safe hands; if one comes into the market it is willingly purchased at a high price. One of the finest violins by this master is in the possession of Ole Buli. $\left({ }^{*}\right)$

(p) This maker is considered ly one of the most recent writer: (Livi), to have been born in 1542 , and to have died in 1609 .

Violins of Gaspard da Salo are rare enough in this country, lut some of the finest of his riolas are in the hands of English collectors. Ole Bull's violin, the celebrated so-called Treasury violin of Innspruck, is fully described by Nessrs. Samdys \& Forster : from a description taken for it, when exhibited at a conversazione of the Nusical fociety of London on the 29 th January, 1\$62, at st. James' Jall. This description ran: "The celebrated "Treasury Violin" of Innspruck, by Giaspard da Salo, with Carytides by Benvenuto Cellini, sculpured ly special command of Cardinal Aldobrandini, and by him presented to the Inseum of Innspruck, in the Tyrol. After the ansault upon the saikl city by the French in $\mathrm{I} S 09$, the XIuseum was phunteres, and the violin carried to Vienna, when the Cuuncillor Rhehazek placed this mique gem in his celebrated collection of ancient musical instruments, refusing to sell it at any price. He left it by will to Ole liull in $\mathrm{IS}_{4} 2 . \mathrm{U}_{\mathrm{p}}$ to that period it had never been played upon; had nu, bar, only a bridge of hoxwook, sculptured and painted, and a rery short and inlaid tingerboard." This interesting instrument is now in . Incrica. Another remarliable violin is the one owned ly Mr. W. A. Tysen-Amberst, now Lord Amherst. Many fine double-basses by Giaspard ta talu are in existence, notably the celebrated instrument belonging to signor I ragonetti, which he bequeathed to the Churchwarlens of St. Marlis, Venice. This famous player also owned the gigantic threestunged instrument which he left to the Duke of Leinster, which is in the Sumb kensington Nuseum; the Amati loulle-bass, which he left lu Mr. Canuel Appleby, of Brighton; and a Stradivari double-bass, which be ledt to the municipality of Venice. One of the most perfect handi di camera hy this maker was found in the collection of Tarivio; it affersarts passed inse the possession of Mr. Bennett. A small lass viol with six strings is in the Insée du Conservatoire, Paris, and a four-stringed combiallans, alse hy Gaspard da Saln, in the same collection; the latie $\mathrm{r}$ instruncent dates from about 1580 , it belonged to 11 . Boulart, then (n) .1. liature. 
z76. SANONI, Giovanni Baptista. Verona. A high model ; very few instruments by this maker are to be found.

I 77. SANTI. Giovanni. Naples, r 700-1 730 . Model after that of Nicolas Amati; brittle varnish and insignificant workmanship. $\left(^{q}\right)$

I 78 . SANTINO, Sanzio. Milan, I634. Of no particular value.

I 79. SANZO. Milan. Similar to Grancino.

I8c. SANZZA, Santino. Milan. Similar to Sanzio Santino, and possibly identical with him.

181. SEPINI, or Sapino. Cremona, i640. An imitator of Cappa, of the Amati school. Many of his violins are extremely good, and have a handsome, golden-red varnish.

I82. SERAPHIN, Santo. Venice, I730-1745. With Montagnana he is the most

Sanctus Seraphin Utinensis Fecit Venetiis Ann. I7- celebrated Venetian maker, and in the artistic execution of their instruments the best of them excelled those of Stradivarius. He often changed the model of his violins; there are some made after that of Stainer, others after that of Nicolas Amati, while still others much resemble those of Francesco Ruggeri. The varnish is handsome, brownish-red, and put on thickly on the backs, whereby it has come off in parts by use. As his models differed, so he varied in the marking of his instruments, either by his name branded on them, or by large ornamental labels or by small labels. His violoncellos are usually better than his violins. $\left(^{r}\right)$

I83. SERASATI, Jomenico. Naples, I 7 Io-I 750. Of mediocre merit.

(q) Or Sante (?) This name also occurs at Pesaro and in Rome. Some confusion has occurred between the names of Santi, Sante, and Santo.

(r) He used a large label, which he is said to have himself engraved, and which is very elaborate and handsome. Some of his violins are found with his initials in ebony let into the belly under the broad part of the tail-piece. He principally followed Nicolas Amati, and one authority cites a label to show apf arently that he was his pupil. 
I84. SIANI, Valentino. Florence, i6jo. He made instruments refined in

\section{Valentino Siani} Florenz I6model and in construction. The vamish is brown, and is of a beautiful quality. The tone is not strong, but is noble and sympathetic. Siani made excellent violas.

I85. SPEILER. The Tyrol.

I86. STAINER, Jacobus. Cremona, and Absom in the Tyrol. He was during the

Jacobus Stainer in Absom prope Oenipontum 16-- whole of his life a poor man, followed by every imaginable misfortune, who was after his death elevated to an ideal position.

Stainer was born on the I t th July, I62 I, at Absom in the Tyrol. ( $\left.{ }^{s}\right)$ As a boy he worked with an organ-builder at Innspruck, but as he was weak in body he took to a lighter occupation, violin-making, and, by means of the benevolent assistance of his parish priest, contrived to reach Cremona. There he is said to have worked under Nicolas Amati; but of this proof is wanting, and there is nothing in his work to show the influence of this master.

History also relates that Amati sought to secure Stainer on account of his talent, and desired him to marry his daughter, but that this did not suit Stainer's wishes, and that to evade Amati's intentions he went to Venice and worked under Vimercati.

When hardly twenty years old he returned to Absom, his native place, and made violins for the market at Hall, for which his price was six guldens.

On the 7 th October, I 45 , he married Nargaretha Hobzhammer, which union was blessed more with children than his art with remuneration, and the family fell into trouble and debt. $\left({ }^{t}\right)$ On the $29^{\text {th }}$ October, $165^{8}$, Stainer was

(s) According to the parish registers of Alsom which are preserved in the church of Hall, he was the son of Martin Stainer and Sabine Grafinger.

( ) See "Der Geigenmacher Jakoh, Stainer." liy S. Ruf. (Intspruck, Wagner, 1872.) Hic was marricel on the 261 h Nivemler, 16.15. 
raised to the rank of Archducal Retainer by the Archduke Leopold, and on the gth January, r669, he received the distinction of "Court Violin-maker" from the Emperor. After these honours he was accused by the Jesuits of the crime of heresy, and lay in prison for six months in consequence. After this he got deeper into trouble, went out of his mind, and died insane in $168_{3}$. His wife and eight daughters survived him. In his house is still shown a stone bench to which he was chained when he was insane.

Whatever may be attributed to the work of Stainer, it furnishes evidence of the master's great genius. The technical work has never been excelled, and if Stainer had not been obstinately and firmly attached to the high-arched model created by him, he would have followed the old Brescian pattern more, and the question is whether he could not then have excelled every one in power of tone, as he certainly did in beauty.

The hills near Absom were covered with the finest pinetrees. There Stainer chose the planks for the bellies of his instruments, and as much as possible a round-veined maple for the backs and sides.

That Stainer at one time lived in Cremona we see from a certain number of his violins, which are dated from that place; they are for the most part small instruments, with the bellies of rather broad-grained wood. The labels in them are in his handwriting. $\left({ }^{*}\right)$

When he returned to Absom he enlarged his model, without otherwise altering its character. His violins are rather broader and shorter than those of the Italian makers. The belly is made higher than the back; the $\mathrm{F}$ holes are short, and spread out into circular holes; the corners project widely. The neck has often, instead of a scroll, a well-carved lion's head. Where Stainer has put a scroll, it is more curved, but is otherwise commonplace. The yellow-red

(u) Otto says he made his violins in three sizes, a large size, medium, and small. Tartini used a fine Stainer violin, with a bright yellow varnish; it was shown in the Exhibition at Milan in $\mathbf{I} S S_{I}$. Mr. A. E. Donkin now possesses the well-linown viola by him formerly belonging to Count Castelbarco. 
varnish is exceedingly handsome. Occasionally Stainer has put a third sound-hole in the shape of a star under the finger-board; it may be noticed that in these cases the $F$ holes are narrower than usual.

His violoncellos are on the model of the contra-bass, that is to say, the upper part of the sides slope downwards on a curve with the neck of the instrument. Stainer is said towards the end of his life to have made twelve violins of extraordinary beauty, and to have intended them as presents for the twelve Electors. This story of the so-called "Elector violins" must, howerer, be banished into the company of mere legends. $\left({ }^{*}\right)$

I87. STAINER, Marcus. Knefstein, I659. A brother of Jacobus. $\mathrm{He}$ Marcus Stainer Bürger und belonged to a monastic Geigenmacher in Knepstein anno r6-order, and assisted his brother in the business of violin-making. The virtuoso Veracina possessed two violins by him, which he called St. Peter and St. Paul; these are said to have surpassed the best Italian instruments in fulness of tone. Veracina lost these violins in a shipwreck in the Mediterranean Sea. ${ }^{(w)}$

Some violas by this maker are known, which are excellent. They are distinguished, at their best, by handsome wood, darkbrown brilliant varnish, and a large tone of a soft quality. ( $(x)$

I88. STORIONI, Laurentius. Cremona, $\mathbf{i}$ SO-ISO4. $\mathrm{He}$ is the last Cremona

Laurentius Storioni Fecit Cremonae 17- maker of any rejutation. His violins resemble those of Joseph Guarnerius, but

(i) Genuine instruments by Stainer are scarce, while copies, of all qualities, swarm : no maker was more copjed ly German makers and l,y English makers of a certain period. This great popularity assisted to bring the Klotz family and their followers into high favour, a position which, like that of Stainer in a higher degree, has been declining for a long period, and which threatens to sink jet lower.

(iv) This was liancesco Maria Veracini (the younger), whe wan the pupil of Antonio Veracini, of Jilerence. lie lust these violins, generally called st. l'eter and St. l'aul, alwut $17+6$.

(x) Of this family there was also a certain Andreas Staince, of Alsom, in 1660 : he was a maker of viols. 
possess nevertheless a certain originality. There is nothing artificial in his model, and the outlines are powerful and handsome. He had the curious habit of cutting his $\mathrm{F}$ holes in various directions. The varnish is dark brown, and is more in the Neapolitan than the Cremonese style. Vieuxtemps used a Storioni violin for some time for concerto-playing, which had a superb tone, and public attention was thus directed to this maker. ( $\left.{ }^{\prime \prime}\right)$

IS9. STRADIVARIUS, Antonius. Cremona. The fame of this Titan

Antonius Stradivarius Cremonensis among violin-makers Faciebat Anno 17- A $S$ overtops that of all others. He has left us more than a thousand instruments, and each one is a masterpiece.

Stradivarius was born in the city of Cremona, and came of a family of some note, which, as early as the year i1 27 , through one Ottolinus Stradivarius, a senator, found mention in history. $(\tilde{z})$

The year of his birth is not to be found in the registers of the state, and we should be in ignorance on this point, were it not accidentally for one of his instruments, of the year I 736, in which is found the inscription, " 92 years old," in his own handwriting. From this it appears that he was born in $1644 \cdot\left({ }^{a}\right)$

Other credible data concerning his life are as follows: He married and had four children-three sons, Francesco, Omobone, and Paolo; and one daughter, Catherina. With respect to the last, the following entry in the register of deaths appears: "Catherine, daughter of Antonio Stradivari, deceased, living in the parish of the Cathedral of Cremona,

(y) He began to make about $\mathbf{1 7 7 0}$, and died in $\mathbf{1 7 9 9 .}$

( $\sim$ ) For the early references to members of the family, see "Cenni sulla celebre scuola Cremonea degli strumenti ad arco, non che sui lavori e sulla famiglia del sommo Antonio Stradivari." Cremona, tipografia Della Noce, I $\$ 72$. Per sacerdoti Paolo Lombardini.

(a) The actual inscription is, "d'anni 92." 
died $I_{7} \&$, nearly seventy years old, and was buried in the Church of Saint Domenico." $\left.{ }^{8}\right)$

Francesco and Omobono carried on their father"s business in the same house after his death, but Paolo became a dealer in cloth.

The violinist Polledro, of Turin, who died a few years back at a great age, relates that his master had been well acquainted personally with Stradivarius. He describes him as a tall thin man, who generally wore a white woollen or cotton cap on his head. When at his work-and he was always at work-he wore an apron of white leather. As Stradivarius sold his violins for not less than four louis d'or, he acquired a handsome fortune ; and "rich as Stradivari" was the expression used by the inhabitants of Cremona when they wished to describe a rich man.

His house was in the Piazza Roma, No. I 239 , close to the Place S. Domenico, in the nidst of which stood the Church of S. Domenico. It is still in good condition. IVe are indebted to the researches of Signor Sacchi at Cremona for details concerning the end of the great master. It is known that Stradivari purchased, in 1729, a family burialplace in the Church of S. Domenico, but the registers of the Cathedral prove that he was buried in the grave of Francesco Vitani, in the Chapel of the Rosary of S. Mattheo. The omission of the name of the church in which the

(b) The researches of Lombardini have shown that Antonio Stradivari married, on the 4 th July, 1667, Jrancesca Ferrabusclii, the widow of Jean-Jacques Capra, and by her had four sons--lrancesco, forn 6th February, 1670 , died 12 th Feloruary, in the same year; liran. cesco, born Ist February, $167 \mathrm{I}$, died IIth May, 1743; Alessandro, born $25^{\text {th }} 11$ ay, 1677 , died 26 th January, 1732, (a priest), and Omotumo, born I4th November, 1679, died Sth fuly, 17+2; and wo daughters, Giulia, horn 23 rl December, 1667 , who married one Farina, a notary, and died $7^{\text {th }}$ August, 1707 , and Cattarina, born 1 Sth Feluruary, 1674 . diecl, unmarried, 3 rd August, $174 \mathrm{~S}$.

For his second wife siradivari married, on the $2.4 t h$ August, 1699, Antonia Zambelli, by whom he had five children ; four soms- Ciosanni Battista Giuscple, born 6th November, 1701, died 1702 : (iivvanni Battista Martino, born I th Norember, 1703, died Ist Nivember, 1727 ;

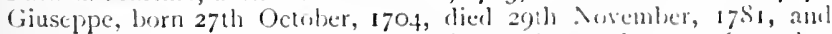
Paolo, born $26 \mathrm{~h}$ January, 1708 , died Ioth Getoler, 17\%6; and a daughter, lirancesca, who was born $1 \mathrm{gth}$ seplember, 1700 , and died, unmarrict, izth letruary, 1720. 
Chapel of the Rosary was led to the belief that the exact spot where his mortal remains reposed had been forgotten. Credit is due to the researches of Signor Sacchi for the discovery that the Church of S. Domenico had belonged to the parish of S. Mattheo, and that the Rosenkranz Chapel is the third chapel from the entrance on the right in the Church of S. Domenico. The parish Church of S. Mattheo was too small, and in 1720 further interments were prohibited, whence the minor Church of S. Domenico became the burial-place for the parishioners. Here Stradivari purchased the grave.

Among the effects of the Abbate Lancetti was found a letter written by Count Cozio de Salabue to Paolo, the youngest son of Stradivari, which runs: "I am pleased to receive the exact information from you that the church in which your father was buried is the Church of S. Domenico." (c)

In another letter of Count Cozio, a year later, is found: "I have ascertained, bejond all doubt, that Stradivari, then nearly ninety-four years old, died at Cremona, in I 737 , and was buried in the Chureh of S. Domenico." The stone bearing the inscription, "Sepolcro di Antoni Stradivari E svoi Eredi An. 1729," is preserved in the town-hall of Cremona.

As further information about the great master is wanting, we must derive the rest from his instruments, which give us a sufficient insight into his life.

It has never been proved that Stradivarius was a pupil of Nicolas Amati, and yet we find from his work that this must have been the fact. Although not one of his instruments bears a date earlier than I688, there are violins with the mark of "Nicolas Amati," in his latest period, which are beyond all doubt made by the hand of Stradivarius; these have not been allowed longer to sail under a false flag, but

(c) It appears from the papers of Lancetti and Count Salabue that at the time of Stradivari's death ninety-one of his violins were in his possession. In 1775 ten of these were in the hands of Paolo Stradivari ; he sold them, as well as two violins by Francesco Stradivari, with the models and tools of Antonio Stradivari, to Count Salabue ; and such models and tools subsequently came into the hands of Count Della Valle. 
have been provided with Stradivari labels. The year in which Stradivarius left the workshop of Amati must have been 1668 . From that time his instruments are in complete harmony with those of his master. Some years later he gave them a scroll with a bolder form, and made them broaler and somewhat deeper. The instruments of this period display wood of a fine quality of tone, though it is not beautiful.

The next period is from 1686 to 1694 . The archings became flatter, the $\mathrm{F}$ holes more elegant and less upright; the design of the middle bouts is more expanded than in his later model, the corners are longer, and the whole instrument becomes larger and the scroll much more powerful. The varnish is differently coloured, often a bright golden colour, clear or dark, often clear red; the latter colour being generally found in those instruments in which the back is jointed. The purflings are fine.

Then comes a period in which Stradivarius adojted a longer pattern, the so-called "patron allongé." It is narrower in the middle, and for this reason appears to be longer. "The colour of the varnish also varies between amber-yellow and clear red, but it is invariably beautifully transparent. These long violins have as fine a tone as the others, and show the same veiled guality of tone, a fact which would hardly be thought possible considering the difference in the model.

In the year $\mathrm{IOS}_{7}$ he made a quartet of instruments for the Spanish Court, inlaid with ivory; of these one violin came into the possession of Ole Bull. $\left({ }^{d}\right)$ At this time he also made

(d) One of the first specimens known distinguished by this kind of work is the violin which belonged to Louis Rode, the violinist: this instrument is now in the possession of an English collector, the owner of a quartet of Stradivaris. It may be pinted out that some of Stradivari's linest work was executed for these special conmissions, for example, the concerto made for the Court of Tuscany, of which one, of 1690 , a very fine violin, is that which recently it is lelieved has been in the handis of Uessrs. W. E. Hill $\mathbb{N}$ Sons, who sold it to an English collector. For the full description and curious history of this magnificent violin, see the first of Messrs. IIill's interesting pulblications on famms instruments and on famous makers "The Tuscan Strad." ISiyo.

This is considered to have been one of the concertos sufplied, in 168.4 and 1690 , to Cosmo III. of Medici. Stradivari also male instruments for the Duke of Alba, for Charles III. of Spain, Augustus King of I'oland, and for the Court of Modenn. 
some small violins with similar ornamentation, possibly for some special orders.

Full of rich experience gained from these experimental works, Stradivarius entered his golden period, which is from I 700 to 1725 . He attained this, the highest point of his art, when he was fifty-six years old.

The outlines are now broadened out, the archings in all respects approach the most beautiful design, and the materials are selected with the most accurate care. The scroll is neat, but less deeply cut, the varnish is of the best quality, and cannot be conceived to be more beautiful. It must not, however, be thought that one instrument is constructed exactly like another. There are differences found in the thickness of the back and belly, in the rounding of the model, in the place of the $\mathrm{F}$ holes, and these give rise to the theory that Stradivarius worked on a wise principle, exactly according to the consistency of the wood or its acoustic properties, which he had studied to a very exact degree.

Whatever may have appeared to the master as an ideal, in order to combine the powerful tone of the Brescian makers with the beautifully clear Amati sound, he certainly brought it into form in a wonderful manner at this period of his labours.

We now come to his last period, $\mathrm{I}_{725}$ to $173^{6}$. The decay of power may now be noticed; the sure hand wavers, and other hands are also helping in the work. The instrument gives as much tone as can be wished, but the perfection of workmanship prevails no more. Who, then, assisted? It is thought that they were his sons, and the faithiul assistant, Carlo Bergonzi; but as their own works, finished independently, in many respects do not resemble the master's instruments of 1725 to 1736 , it is possible he may have wrought them, at all events in the important parts, with his own hand.

The varnish of these later instruments is brown and less clear than that of an earlier date; a few are marked "sub disciplina," or "sotte la disciplina di Ant. Stradivarius. Cremona," from which it appears that he carefully adhered to the principle of marking only those with his name which 
he had himself made, and, on the other hand, caused those to be distinguished with the latter mark which were made by his assistants or under his superintendence.

His few riolas $\left({ }^{e}\right)$ do not show as many rariations as do his violins; they are of a large pattern, and are in every respect not to be surpassed. The violoncellos are made in two sizes. The rirtuoso Servais possessed one (1) of the

(e) Vidal mentions a magnificent viola by Stradivari in the collection of the Duc de Camposelice, who died in Paris on the Ist september, $1 S S_{7}$; in this collection were two violas by Stradivari, a rare possesion, and one by Gaspard da Salo, and one by Nicolo Gagliano. The Camposelice collection is worthy of enumeration : it comprised, lessicles the above, five violins by Giuseppe Guarnieri del Gesi, eight violins and wo violoncellos by Antonio Stradivari, one violin by I'ietro (iuarnieri of Venice, one violin by Santo Seraphin, and a quartet by Nicolas Lupot. A very fine viola of 1690 is in the Istituto Mlusicale of Florence, where there is also a fine Stradivari violoncello of 1790 . The Adam Collection may be fitly compared with the Camposelice cabinet, mentioned above; it contained, inter alia, nine Stradivari violins, all of the first rank; one Stradivari viola; one Stradivari violoncello, and four violins by the great Guarnieri. It may be mentioned that the viola of Mr. Charles Reade, which was subsequently in the collection of Mr. (ieorge Hart, has recently, happily. been acquired by Mr. A. Gilson; it is an instrument of the year 1728 .

( $f$ ) This violoncello of $\mathrm{I} 7 \mathrm{OI}$ is one of the longer pattern, and belonged to II. G. Raoul; it was presented by Princess loussoupow to Servais. It descended to Madame Servais, the widow of Servais fils, who sold it about ISS7 to Monsieur Coutaut, the banker, fur 50,coo lire. Another grand specimen, of the smaller pattern, belonged to Jean-Louis Duport. $\mathrm{His}$ son sold it to Franchomme, the violoncellist, for 25,000 francs. On Franchomme's death, in ISS4, it was sold to a collecior. Among other fine instruments may be mentioned ( $I$ ) that of Signor l'iatti of 1728 , which is believed to have formed part of the collection of the Court of Madrid, (as did also the instrument belonging to signor liatta, which had been in the possession of $\mathrm{H}$. I'lace and of Thiloutst of l'aris. and has recently been in the hands of Messrs. 16 . E. I Iill d Sons). This belonged to Mr. S. I. l'igrott, of Jullin, who sold it to C. IIaucotel for $£ 200$, who sold it for $\delta 300$ to (ieneral Oliver. who presented it to signor Piatti. (2) That of the late King of lortugal, which came from the late Nonsieur Chevillard, of the Paris Conservatuile. (3) The Mara violoncello, of the large pattem. which was hrotght inte England by Johann Baptist Mara, the virloncellist. It pasied from him to IIr. Crossdill, thence to Lord Macdonall, thence to Mr. Lucas, who used it regularly in opera. It then passed into the hands of the late Mr. John Whitmore Isaac, of Joughton l'ark, and the olel liank, Worcester, whose representatives sold it after his death, in I\$S4, (1) Vessrs. W. E. Hill \& Sons. It is now in the possession of an Euglish collector. (4) The well-known violoncello of 1717 , formerly lecknging to Mr. Jonamy Doluree, and now to Mr. E. C. Hoklen. (5) "The lawle violoncello of $173^{\circ}$. (6) The famous instrument which lelonged to Tarisio, of 1725 : it was olstained from syain in fiecer by (hiant 
larger size, which is distinguished by great power of tone and beauty. The violoncellos of the larger size are known in large numbers, but all are unequalled in every respect.

After the death of Stradivarius a number of his unfinished instruments were discovered. These, furnished with genuine labels, came into the market, and continually cause great confusion when they have to be examined and valued. $\left({ }^{g}\right)$

pere and Tarisio, according to the well-known story related by Charles Keade and others. M. Gallay gave Tarisio $£ \& 00$ for it. Herr Hugo Becker possesses an excellent violoncello of I 708 ; and the fine Stradivari violoncello, formerly in the possession of Robert Hausmann, now belongs to Herr Georg Hausmann. The violoncello which formed one of the concerto made for the Spanish Court in 1687, and inlaid and ornamented, is still at Madrid. One of the violins of this concerto was in the possession of Ole Bull and afterwards in the Plowden Collection. M. de Munck possesses a fine specimen, formerly belonging to M. de Barreau. The Vaslin and Gallay violoncello was brought from Italy to Paris by M. Girard of the Société des Concerts, while that of the Pluvié Collection belonged to M. Baudiot, and subsequently to Mademoiselle Jaurès. The violoncello which formerly belonged to Wielhorsky was acquired by M. Davidoff; a superb instrument.

(g) The famous pochette, or kit, by Stradivari, of 1717 , is in the Musée du Conservatoire, Paris. It was brought into France by Tarisio, and sold by him to Silvestre, of Lyons. It belonged to Clapisson, the violinist and composer, and was played upon by Croisilles in Clapisson's opera, "Les trois Nicolas."

It is not known that any complete list of the authentic violins by Antonio Stradivari is in existence, but a few well-known instruments may be roughly enumerated, among which are not included the socalled Greville Stradivari, formerly belonging to Mr. R. D. Hawley, and now to Mr. E. K. Adams, of New York, the violins of Messrs. Wilhelmj, W. Wiener, E. Kemenyi, Waldemar Meyer (the George III. violin), Ludwig, and Lady FIallé (the Ernst violin), and others in the hands of collectors and performers which may be known to the reader.

I688. The violin known as Le Mercure, formerly belonging to the Vicomte de Bioley, then to Sir P. B. Maxwell, and sold at the recent Maxwell sale for $£ 500$.

I690. The Tuscan violin, recently in the possession of Messrs. W. E. Hill \& Sons, and sold by them in August, 1890 , to an English collector. See their book, "The Tuscan Stradivari," I 890.

1699. The violin belonging to the Marquis de Queux de SaintHilaire, mentioned and ilhustrated by Vidal, "La Lutherie," I 889 .

1702. A violin in the possession of Mr. IV. Croall.

1704. (I) The Viotti violin, formerly in the possession of Mr. R. Muir, of Leith.

(2) The Betts violin, now in the possession of the Duchesse de Camposelice.

1 707. The Castelbarco violin, recently belonging to Mr. R. B. Malcolm. 
i90. STRAIIVARIUS, Francesco. Cremona, i 725 .

$17+3$. Son of Anton-

Francescus Stradivarius Cremonensis ius; he worked for

Filius Antonii faciebat Anno 17- several years with his brother Omobono. . .11-

though the master-hand is not to be mistaken in his work, it is inferior to that of his father. It is incomprehensible why he did not adhere to his father's model. He selected an original pattern, with bold but roughly designed outlines. The $\mathrm{F}$ holes are quite different from his father's beautiful design, and he also used a darker varnish of inferior quality. About the tone of his instruments nothing good can be said. He died on the is th May, I 743 .

1709. The violin called La Pucelle, formerly the propery of $\mathrm{M}$, Glandaz, sold at the Hitel I rouot on the it th Felsuary. $1 S 7 S$. for 22,100 francs.

I7 Io. The violin belongirg to Mr. Ries.

1713. The violin from the Boissier Collecion a Nice, now nsed by Señor Sarasate.

I714. The Dolphin violin, from the Adam Colluction, now belonging to Mir. R. Bennett.

1715. (1) A violin in the possession of Herr Joachim.

(2) A violin in the possession of Herr Jonchim.

(3) A violin in the possession of Senor Sarasate.

(4) A violin in the possession of Mr. IIaddock, of Leeds; formerly known as the Gillott Stradivari.

15) The Alard Stradivari.

I7I6. (I) The Cessol, or Artot, violin, now Mr. W. Croall's.

(2) Tine Messie violin, now helonging to Mr. K. Crawford. See "The salabue Stradivari,"W. E. Hlill d tons, ISgo.

(3) A violin in the Istituto Musicale, Florence.

1717. A riolin belonging to Mr. J. G. Orchar.

1720. The Woolhouse violin, sold Lec. 6th, I\$93, for $f_{620}$

1723. An excellent example, formerly in the possession of the late Duke of Cambrikge, now belonging to H.K.H. the Duke of Edinburgh.

1732. The violin belonging to Mr. Arliwright, exhilited in is 72 at south Kensington; it was bouglut ly signor l'iatti from the Castelbani Collection at Naples.

1736. (I) The Munt $z$ violin.

(2) The Fountaine violin. For an account of this instrument, see Mr. Ilart's "The Violin." One of these instruments was recently in the hands of Mesors. Ilill de sons.

1737. The Chant du Cygne violin, formerly lelonging to the late . M. de Saint-tennoch, sold at the llotel bruten, for 15, OCH francs. This instrument lears the words, "d'anni 93." in the maker's writing. 
19r. STRADIVARIUS, Omobono. Cremona, r7251742. The second Omobonus Stradivarius figly Antony son of Antonius. $\mathrm{He}$ Cremone fecit,-_Anno i7 worked but little. A violoncello by him is known, which is a plain instrument without any particular merit as to tone. He died on the $5^{\text {th }}$ of June $\left.174^{2} .{ }^{h}\right)$

I92. SURSANO, Spirito. Coni, I7I4-1735. Of the Amati school.

193. TANEGIA, Carlo Antonio. Milan, i 730. Similar Carolus Antonius Tanegia fecit to Grancino. in Via lata Mediolane anno $17-$

194. TECHLER, David. Rome, r680-r743. Of German descent. He

David Techler Liutaro

fecit Romae An. D. $r_{7}$ worked at Salzburg, Venice, and Rome, at first after the Stainer model, and later in better style after that of Nicolas Amati. Techler was compelled to leave Venice on account of the pursuit of his competitors, who threatened to murder him. His instruments are of much merit, especially his large violoncellos. He used a yellow varnish, thinly put on atter the fashion of Nicolas Amati. $\left({ }^{i}\right)$

195. TEODITI, Hieronymus. Rome. But little known.

r96. TESTATOR il Vecchio. Milan, I560. According to "La Luthomonographie," he was the oldest Milanese maker, and the first who made a violin after the fashion of a viola.

(h) A label of this maker is also known, "Omobonus Stradivari figlij Antonij Cremone. Fecit anno $\mathbf{1 7 - a}$ Td."

(i) Techler was born in 1666. Many fine violoncellos of his are known, notably one which is the property of H.R.H. the Duke of Edinburgh. It has been found necessary to cut down the largest instruments on account of their disproportionate construction. Of his earlier violins not much can be said; they are modelled very high, and are weak in tone. 
197. TESTORE, Carlo Giuseppe. Cremona, 1690-

Carlo Testore me fecit Cremona del Anno r6-

I 710 . He was probably a pupil of Joseph Guarnerius, whom he copied well, and his instruments take a high place in the opinion of comnoisseurs, as well as in price. The workmanship is good as a rule. Bottesini possessed an excellent contra-bass by him. $\left({ }^{j}\right)$

igS. TESTORE, Carlo Antonio. Milan, I;00-r $73^{\circ}$. He copied Nicolas and
giore del fu Carlo Giuseppe in Con Joseph Guarnerius; he giore del fu Carlo Giuseppe in Con trada largo al segno dell' Aquila Milano I7worked very well, and one of his violins is known to be excellent. $\left(^{(}\right)$

199. TESTORE, Paolo Antonio. Milan, 17 Io-1 745. Brother of the last maker: he worked after the model of Joseph Guarnerius. His instruments are generally without purfling; he used a yellow varnish. (')

200. TONONI, Carlo Antonio. Venice, r 700 ; and

20I. TONONI, Giovanni. Venice, r $709^{-1} 740$. They' worked after various models; the flat-modelled violins are good ; the varnish is a clear brownish-red. (")

202. TONONI, Joannes. Rome, 17 ro. Of no special merit.

203. TONONI, Felice. Bologna and Rome, I 730 . Pather a high model. The ramish is a bright yellow, and is very good.

204. TONONI, Guido. Bologna and Rome, $175^{\circ}$

(j) The small contra-bass often used by Bottesini for solo-playing was by this maker. Carlo Giuseppe was a pupil of Cappa, it is considered : he worked also at Milan.

(k) Ile had a son Ciovanni, who workerl at the business: of him little is known.

(l) He made a certain number of violins of an inferior order: he also made fine cithers. He worked to 1759 . His label is, "l'aulo Antonio Testore Milano 17-."

$(m)$ Much confusion exists as to the relationships between the mem. bers of the Tononi family. There was a Cark Antonio Tomoni who worked at Venice until alsout 1768 . Ciuvanni used a label, "Joannes Tunonus fecit Bononia in plater l'avaglionis anno $1690 . "$ 
Some violins by him, after the model of Nicolas Amati, are known.

205. TORTOBELlo. Rome, i680. A follower of Maggini.

206. TRUNCO. Cremona, I660. But seldom found.

207. VETtRini. Brescia, i6-. He used a handsome flat model, and good wood, with a golden varnish. $\left({ }^{n}\right)$ 208. VIMERCATI, Pietro. Venice, I640-1660. Similar to the Brescian makers. Jacobus Stainer worked under him.

209. VIMERCATI, Paolo. Venice, i 7 ro. Son of the last, he made small instruments after the style of the elder Amatis. Good yellow varnish. $\left(^{\circ}\right)$

2 го. VINACCIA, Antonio. Naples, $7_{7} 6_{5}$. Of no importance. $\left({ }^{*}\right)$

211. ZANETTO, Peregrino. Brescia, r530-1540. He made viols principally,

Peregrino $Z$ anetto

Brescia 15 -

but some riolins and violoncellos also, which are excellent, and are valued as solo instruments. $\left(^{a}\right)$ Eichhorn, the Carlsruhe player, possessed a violoncello of extraordinarily large and noble tone, for which high sums were offered him; and a violin by Zanetto in the Niederheitmann Collection has a similar tone of much excellence. The model is rather large and highly arched, the varnish a dark brownish-yellow. The $\mathrm{F}$ holes are long and after the style of Joseph Guarnerius.

(n) His name was Battista Vetterini, or Vetrini: he lived about I629.

(o) There was also a Gaspare Vimercati about I 700, of Milan, a noted maker of lutes and mandolins.

( $f$ ) For other members of the Vinaccia family, see Appendix. Antonio Vinaccia was a maker of lutes, for the most part.

(q) His name also runs Pelignino, or Pelegrino, Zanetto. $\mathrm{He}$ is certainly known as a viol da gamba maker, but the authenticity of his violoncellos as original instruments is doubtful. There is a very fine bass-viol, attributed to him, and dated $15+7$, in the Musée du Conservatoire, Paris. (See ante, Montechiari.) It was brought from Italy by Luigi Tarisio, and belonged to Norblin, the first professor of the violoncello at the Conservatoire, IS26 to IS46. 
For violin-bellies he used the wood of a crooked tree, whence the graining runs in uneven lines. The scroll is handsomely curved, and resembles that of Gaspard di Salo.

2r 2. ZAN'T, Alessandro. Mantua, 1765-1;70. A follower of Pietro Guarnerius. Good workmanship, but bad varnish. 


\section{CONCLUSION.}

As it is a matter of the greatest importance for a singer to have a beautiful voice, so is it equally important to instrumentalists, and particularly to solo-players, to possess an instrument with fine tone. What is a fine tone? A tone can neither be weighed, nor measured, nor seen; we find it produce an effect on our innermost feelings through the power of hearing, and after it has worked upon our mind, we make an estimate whether it is more or less beautiful. As different people are endowed with different minds, so their opinions differ as to the quality of sound which an instrument possesses. What one finds soft and beautiful appears to another dull and faint; what one takes to be strong and powerful sounds commonplace to another. There are instruments, however, which are designated by all, without a difference of opinion, as possessing the finest tone, and suited to every taste; and these must be truly kings among musical instruments.

Among these, in the first rank figure those of Antonio Stradivari and Joseph Guarneri, which please every ear and delight every listener. Why is this? If we analyse the tone of these instruments by our sense of hearing, their charm lies peculiarly in their combination or blending of sounds. It comprises reminiscences of the flute, the oboe, the horn, and the clarinet, and the artist has it in his power by a particular touch of the strings with the bow, by a particular management of the bow, and by a peculiar combination of positions, to draw forth those delicacies of expression which his feelings suggest to him. The artist can chant and sing, rejoice and entreat, and he can express every feeling on one 
and the same instrument. Thus he needs but an instrument which contains the capacity of producing these nuances of expression; and this is found in the highest degree in the instruments of the above-named masters.

There are violins which produce but one species of tone; for instance, that of the oboe. These are but tedious instruments; from them, throughout the register, only a thin, nasal, oboe-like tone can be drawn, which can warm no player and enchant no listener. It signifies nothing that the tone is loud and penetrating, and if the owner is questioned, he usually answers plausibly that it is exactly the point, and that it is a famous historical violin, for which he has already been bid such and such a price.

If we translate the expression "beauty of tone" into "tone blending of sounds," it remains to be solved what the nature of blending of sounds is. It originates in the simultaneous combination of aliquot tones (principal or natural tones) which belong to the same tonic, and the stronger those are in the octare, the fifth, the next octare, the third, the fifth, and the seventh, the more beautiful is the tone, and the more perfect is the instrument.

In the royal Resonatoren-Apparat, (the description of which is too long to be given here), a method is provicled of estimating aliquot sounds; by its system it may be seen how many natural tones there are, and how they combine.

Modern violin-making is in tone-production still far distant from supplying masterpieces like those achieved by a Stradivarius; from that point of view a great gulf livides them. But why should not that point be again attained which once has been accomplished? Until then the violinmaker can do nothing better than follow, and keep rigidly to, the model which is provided for him by the greatest masters. And when this model is attained, then should the art of violin-making go upwards and onwards in its career. 


\section{APPENDIX.}

\section{MINOR MAKERS AND MAKERS OF LUTES, \&C.}

ABBATI, Giuseppe. Modena, about r770-1795. He is noted for his basses. There appears to have been also a Giambattista Abbati, or Abati, who worked about the same time at Modena, though the two may perhaps be identical.

ADANI, Panerazio. A cither maker.

AGLIO, Giuseppe dall'. Mantua. He worked in the earlier part of the present century.

ALESSANDRO. Venice, I 5-.

ALBERTI, Ferdinando. Milan. One of the Grancino school. He worked in the middle of the eighteenth century.

ALBERTO, Pietro. Bologna, about 1600 . A celebrated lute-maker.

AMBROSI, Pietro. Brescia. His label is, "Petrus Ambrosi fecit Brixiae, r 7-."

AMBROSIO, Antonio. Naples, is-.

ANDREAS, Johannes. Verona, I5II. He was a violamaker, according to Dr. Schebek. An elaborately carved lyra da braccio, marked "Joannes Andreas Veronensis a di I 2-- uosto I 5 I I," was exhibited in Vienna in 1892.

AN'TAGNATI, Giovanni Francesco. Brescia, r 530. A lute-maker. His name is also written Antognati. He was the first known maker at Brescia, (Lanfranco).

ANTONIAZZI, Gregorio. Colle, about $\mathrm{r}^{78} 8$. His label is, "Gregorio Antoniazzi in Colle $1738 . "$

ANTONIO, Il Ciciliano. There is a viol da gamba by this maker in the Museum of the Lyceo Filarmonico at Bologna.

ANTONIO, Il Bononiensis. A viol da gamba by him is preserved in the same museum.

ANTONY, Hieron. A good violin with his label is in the collection of the Marquis de Saint-Hilaire in Paris. A good model, yellowish varnish. 
BAGNINI, Orazio. Florence, 1660-1670. A cithara maker.

BAJONI, Luigi. Milan, $\mathrm{I}_{40}$ to about isSo. He made some good violas, medium size, good wood, and a reddish-brown varnish.

BARALDI, Giovanni. I566. $\mathrm{He}$ is known as a maker of the lyra di gamba.

BARBANTI, Francesco Silva. Corregio. I modern maker of no special note.

BARBI, Michael. A lute-maker who worked in Venice about $\mathrm{I} 74+$.

BARNIA, Fedele. Venice, about 1;60. A maker of theorbos.

BASSIANO. Rome, i666. A lute-maker. An archilute, marked " Bassiano liuttaro in Roma i668," was shown in Vienna in I S92.

BASSO, Joanes Antonius. Venice, I574. He is known principally as a clavicembalo-maker.

BASTOGI, Gaetano. Livorno, 17-. A maker of lutes.

BATTISTA. Brescia. An ancient pochette by him exists in the Museum of the Lyceo Filarmonico at Bologna. There was also one Giovanni Battista at Naples about 1751 , a mandola-maker. There was a mandolin by this maker marked 1796 in the Zach Collection at Vienna, I 892.

BECHARDINI, Giovanni. Venice, i60\%. A lutemaker.

BELAMI, Paul. 1612. An Italian lute-maker, who worked principally in Paris.

BELLONE, Pietro Antonio. Milan, I690-1 700.

BELVIGLIERI, Gregorio. bologna, I $7+2$.

BERATI, Joannes. Venice, I 7 -

BERETTA, Felice. Como, $178+$ A pupil of Giuseppe Guadagnini.

BERTASIO, or Bertassi, Luigi. Piadena, 1738.

BERTI, Antonio. Crotona, ahout 1720 .

BER'TI, Antonio. Florence, 17+5. Probably identical with the preceding maker.

BIANCHI, Nicolo. A good repairer, who worked at Genoa in the middle of this century.

BOMBLRGHI, Lorenzo. llorence, 17-.

BONORIS, Cesar. Mantua, about 1565 . A maker of viols.

BORTOLETTI, Luigi. About I \& 5 . A mandolin-maker.

BOSI, Floriano. Bologna, about 1780.4 mandulinmaker. 
BRAGHIA, Antonio. Modena, I7-.

BRANDIGLIONI. Brescia, I6-.

BRANZO, Barbaro. Padua, I620-I660. A lute-maker.

BRENSI, Girolamo (or Brensius, or Brensio). Bologna, eighteenth century. A viola da bracchio with his label is in the museum at Bologna; the inscription is, "Hieronymus Brensius Bonon."

BRESA, Francesco. Milan. Very little is known of this maker: he worked at the commencement of the eighteenth century.

BRESSANO, Baptista. I500. A lute-maker.

BUEETENBERG, Matteo. Rome, i597-i6io. He mades lutes and archilutes. The name also runs Buchenberg and Bueckenberg.

BUGGIANO. I6rs. He is believed to have been a maker of spinets.

BUONFIGLIUOLI, Pietro. Florence, i6-.

BUSSOLERO, Luigi. Rivanazzano, I\&I7. A maker of guitars and mandolins.

CABROLI, Lorenzo. Milan, I7-.

CAESTE, Gaetan. Cremona. He worked in the latter part of the seventeenth century.

CALCAGNO, or Calcagni, Bernardo. Genoa, about I 700. Of the Stradivari school ; red varnish. His label is, "Bernardus Calcanius fecit Genuæ, anno I 7-."

CALONARDI, Marcus. Cremona, i6-.

CALVAROLA, Bartolomeo. Bergamo, I 753-1 769 .

CARBONI, Giuseppe. Turin. He was working in I 878: he has made a large number of instruments of medium quality, and used generally a bright reddish varnish.

CARCANIUS. Cremona, I500. Little or nothing is known of this maker.

CARCASSI, Lorenzo and Tomo. Florence, about 1740.

A Francesco Carcassi is also known.

CARLOMORDI, Carlo. Verona, about $165^{\circ}$.

CASPAN, Giovanni Pietro. Venice, 16-.

CASSANELI, Giovanni. Ciano.

CASTELLANI, Pietro. Florence. He made cithers principally: he died in $\mathrm{I} \& 20$.

CASTELLANI, Luigi. Son of Pietro, born iSo9. One of the best makers of cithers.

CASTAGNERI, Gian Paolo. Paris, r 735. An Italian maker, of Cremona, who settled in Paris. His label is, "Castagneri Gian Paolo nel palazzo di Soissons in Pariggi." He had a son Andrea, who worked with him. 
CATI, Pietro Antonio. Florence, $17+0$.

CATENAR, Enrico. Turin, I6 7 I. He is said to have been a pupil of Cappa. His label is, "Henricus Catenar fecit Taurini anno I67 I."

CATTENARO. Pavia, I639.

CAVALORIO. Genoa, about 1720.

CELLINI, Giovanni. Florence. $A$ lute and viola maker: he died in 1527 or 1528 .

CERIN, Marco Antonio. Venice, I793. A pupil of Belosio. His label is, "Marcus Antonius Cerin, alumnus Anselmii Belosii fecit Venetix, an. I 793."

CERUTI, G. B. Cremona. He died in I 8 I , having succeeded Storioni in I 790 . Copyist of Nicolas . Imati.

CERUTI, Giuseppe. Son of G. B. Ceruti. l)ied in I $S_{5} \circ$. He made a few good instruments.

CERUTI, Enrico. Son of Giuseppe. Born r 808 , died recently. He made good instruments: his work gained a number of medals at various exhibitions. A firm is working at Cremona under this name at the present time.

CHIARELLI, Andrea. Messina, I698. A maker of lutes and theorbos. Vide Fétis.

CHIAVELIATI, Domenico. Lonigo, I 790-1 Soo.

CHIOCCI, Gaetano. Padua. He was working very lately.

CHRISTA, Giuseppe Paolo. MIonaco, i $7-$.

COCKO, or Cocco, Christoforo. Venice, I 654 . The Conservatoire of Paris possesses an archilute with this maker's label : it is, "Christofer Cocko, All' insegna dell" Aquila d'oro Venetix, I654." (No. 149.)

CONBLE, Ambroise de Tournay. A workman of Antonio Stradivari. His instruments are not much known in England, they are not as a rule highly finished, but possess much merit, and have an excellent tone. His basses are noted. He used a fine oil varnish, sometimes approaching a golden colour, and thickly laid on. The labels are in manuscript, one, in the editor's possession, is, "fait a Tournay par Ambroise De Comble I 750 ." De Comble worked from about i 720 till about 1756 . He failecl in his $\mathrm{F}$ holes, which are occasionally coarse and bactly cut. During the latter part of his life he carried on business at Tournay, which causes him usually to rank as a lilemish maker. $A$ fine quartet of instruments by be Comble, the property of l'rince Caraman-Chimay, was exhibited in the Paris Exhibition of 1878 , displaying good workmanship and a beautiful reddish-brown varnish. 
CORDANO, Jacopo Filippo. Genoa, I774. His label is, "Jacobus Philipus Cordanus Fecit Genuæ, anno sal I 774."

CORNELLI, Carlo. Cremona, I 702.

COSTARO, Antonio. Rome, 16r5. A maker of lutes.

CUNI. 17-. But little known : he is said to have made violins of a very flat model.

CUPPIN, Giovanni. He made principally basses.

DECONET, Michele. Venice, I750. His name is also written Deconer. Herr Scholl, of Trieste, has a viola labelled r 7 12. A member of the family worked at Padua in 1769 .

DEGANI. A firm now working at Venice.

DELLA CORNA, Giovanni Paolo. Brescia, I530. A lute-maker. It would appear that an earlier maker of this family existed, about I 484 - Gian Giacomo Della Corna.

DIEFFOPRUCHAR. The Italian form of Tieffenbrüker. (See Tieffenbrücker, and ante, Duiffoprugcar.)

DINI, Giambatiista. Lucignano, I 700-I 7 Io.

DOMINICELLI. Brescia, I 7 -.

DONATO, Serafino. Venice. A maker of lutes, of the earlier part of the fifteenth century.

D'ONEDA, Gio. Battista. Brescia, I 529.

DONI, Rocco. Florence, about I625 to 1655 . He made basses.

DRINDA, Giacomo. Pianza, 7 -.

EDLINGER, Joseph Joachim. A Prague maker. He also worked at Ferrara and Rome. His lutes are famous. There was also a Thomas Edlinger, who worked at Augsburg, a viola da gamba maker.

EMILIANI, Francesco de. Rome, i 729. Of the Techler school.

EVANGELISTI. Florence, i 7-.

FABRICATORE. A family of makers of guitars, mandolins, \&c., who worked at Naples in the second half of the eighteenth century. Their labels mention the names of Giovanni Battista Fabricatore and Gennaro Fabricatore.

FABBRIS, Luigi. Venice, $18-$.

FACINI, Gostino. I $73^{2-1} 74^{2}$. Some good instruments of his are known. He was a monk.

FENDT, Bernardo. The elder Fendt, of Innsbruck, is considered to have worked under Bergonzi for a time at Cremona.

FERATI, Pietro. Sienna, I764. He made a number of violins, and used a brown varnish.

FERRARI, Carlo. Sienna, about I 740. 
FERR ARI, Alfonzo. Carpi. A relation of Carlo, about the same date.

FERRARI, Igostino. Budrio.

FIORINI, Raffaello. Bologna, 1\$67. His son, Ciuseppe, is working at Milan and Turin.

FIORINO, Fiorenzi. Bologna, $168_{5}$.

FILANO, Donato. Naples, 1770-178z. A celebrated mandolin-maker. A label of his in an instrument shown at Vienna, I $S_{92}$, is, "Donatus Filano fecit anno I). 17\%1. Neap. alla Rua de Taffellanari." There appears to have also been a Giuseppe Filano.

FICKER, or Fiscer, Giuseppe and Carlo. Milan, about 1764 .

FONTANELLI, Giovanni Ciuseppe. Bologna, 17331773. A famous maker of mandolins and lutes. His labe] is, "Giovanni Giuseppe Fontanelli bolognese f. an. 17-." The Nusée du Conservatoire Nationale of Paris possesses two good mandolins by him of 1771 and 1772 . (Nos. 160 and 16 I.)

FORNARI. Venice, I 790. He is known principally as a maker of wind instruments, and may have been merely a dealer in bowed instruments.

FREDLMAUR, Joannes Baptista. Florence, 1740. Very little is known of this maker, but some violins of good quality pass under his name, instruments of no great power, with a light orange varnish.

FREY, or Frei, Hans. Bologna. He was a maker of lutes and viols, and was connected with, or was identical with, the Nürnberg maker of the same name, who worked from about 5570 to 1597 , and was father-in-law of Albrecht Durer.

GAFFINO, (iuseppe. Paris, 1760 to about i 7 So. 1 pupil of Castagneri.

GALBANl, Pictro. Florence, about $16+1$.

GAllBUSER A, Carlo Antonio. Milan, abont i $\$ 20$ to I $\delta_{30}$. This maker invented a guitar-shaped violin.

GiLTAN1, Rocco. Florence, 16-.

GiSP.IN. The name ascribed to one of the oldest native Italian makers. (See Caspan.)

GATINARI, Enrico. Turin, I670.

(i.l'TINARI, Francesco. 'lurin, about 1700. His label is, "Francesco Gatinari Fecit 'laurini Anno l)omini I 704 "

GENAIRO, Giacomo. Cremona, 16.4. I workman of Nicolas Amati. 
GERONI, Domenico. Ostia. He worked in the early part of this century. .

GHIDINI, Carlo. Parma, I 7-.

GHERARDI, Giacomo. Bologna, 1676 .

GIANOLI, Domenico. Milan, $75^{\circ}$.

GIBERTINI, Antonio. Parma, I83o. He made some good violins.

GIGLI, Julio Cesar. Rome, about I 750- 1765 . His labeI is, "Julius Cesar Gigli Romanus Fecit Romæ, anno 1761 ."

GIRANIANI. Livorno, I 730.

GREGORI. Bologna, I $790-\mathrm{I} 800$.

GRISERI, Filippo. Florence, I6-.

GROSSI, Giuseppe. Bologna, i 800.

GRULLI, Pietro. A maker carrying on business in recent years at Cremona.

GUARMANDI, Filippo. Bologna, I8I4. A guitarmaker.

GUDIO, Hieronimus. Cremona, 1727. A very fine viola d'amour by this maker is known.

GUERRA. Modena, I 800-I 8 I o.

GUGLIEMI, Giobattista. Cremona, about I $75^{\circ}$.

GUILLAMI, a family of Spanish makers, of Italian origin, who worked between 1680 and i 780 .

HAMMI, Johann Gottfried. Rome, I720. A German maker established at Rome.

HARTUNG, or Harton, Michael. Padua, I602-1620. A lute-maker, pupil of Leonhard Tieffenbrücker.

INDELAMI, Matteo. A maker of lutes.

JADRA, Marcus. I568. A maker principally known by his spinets.

JORIO, Vincenzo. Naples, i 8-.

JULI, Nicolas. An Italian, settled at Lyons, I 573.

KAISER, Martin. Venice, r609. A lute-maker : a fine archilute by this maker is in the Musée du Conservatoire, Paris.

KOLL, Giovanni. Monaco, I6-.

KRAMMER. Monaco, $\mathrm{I} 7$ -

KREBAR, Giovanni. Padua, I629. A maker of lutes and theorbos.

LAGETTO, Luigi. I 750. An Italian maker established in Paris: his label is, "Louis Lagetto Luthier rue des Saints Pères Faubourg Saint Germain à Paris à la ville de Crémone."

LANDI, Pietro. Sienna, about $\mathbf{I} 775$.

LAVAZZA, Antonio Maria and Santino. Milan, about 
1700-1 7 IS. Their labels are, "Antonio Maria Lavazza fece in Milano in contrada Larga, 1708 ," and "Santino Lavazza fece in Milano in contrada larga 1718 ."

LEONI, Ferdinando. Parma, isr6.

LEONI, Carlo. Treviso. He worked in recent years principally as a repairer.

LIGNOLI, Andrea. Florence, is-.

LOLY, Jacopo. Naples, 16 -. Of the Grancino school.

LONGO, Magno. A lute-maker of Padua; he worked about I $_{598}$.

LORENZINI, Gaspar. Piacenza, I 7-.

LUDICI, or Ludge, Geronimo Pietro. Conegliano, 1709. An amateur, apparently, according to his label, which states that he worked "Animi causa."

LUGLONI, Giuseppe. Venice, I 7 -

MAFFEOTO, Giuseppe. Rome, I7-.

MANTOVANI. Parma, I7-.

MARCELLI, Giovanni. Cremona, about i 699-1 700 .

ILARCHETTI, Enrico. Turin. He was living in 1887 .

MARCHI, Giovanni Antonio. Bologna, about 1774 . He made some good violins.

IARCONCINI, Luigi. Ferrara and Bologna. A pupil of Omobono Stradivari. His label is, "Luigi Marconcini in Ferrara, I $767 . "$

MARCONCINI, Giuseppe. Ferrara. Son of Luigi.

M.ARCO, Antonio. Venice, about 1700.

IARIA, Giuseppe de. Naples, about I 700. A celebrated maker of mandolins and mandoras.

MARINO, Bernardo. Rome, ISoo.

MEIBERI, Francesco. Livorno. He worked in the middle of the last century.

MELINI, Giovanni. Guastalla, 17-.

MELONI, Antonio. Milan, about r690. In imitator of the Amatis.

MERfGHI, Pietro. Parma, about i 790. A maker of mandolins.

MERT', Raphael. Padua, I630. 1 lute-maker, a pupil of Michael Hartung.

MIGLIALS, Antonio de. Florence, I 696 . 1 claricembalo-maker.

MOLINARI, Antonio. Venice, 1675-1700.

MOLINARI, Joseph. Venice. He made principally theorbos and mandolins. A fine specimen, of 1763 , by him is in the Musée du Conservatoire, l'aris. (No. 159.)

MONTANI, Geegorio. Cremona, 17-. 
MONTECHIARI, Giovanni. Brescia, about i60o. A maker of lutes and citharas. It is thought that some confusion as to dates exists here, that this maker was, in fact, the elder Zanetto (da Montechiaro), the father of Pelegrino, or Peregrino, Zanetto.

MORONA, Antonio. About 1730 . This label is, "Presbyter Antonius Morona, Insulanus ex Istria fecit, I73r."

NADOTTI, Giuseppe. P'iacenza, about i $7 \sigma_{5}$.

NICHOLAS. Geneva, about 1790.

NIG(;EL, Sympestus.

NOVERSI, Cosimo. Florence, i6-.

OBBO, Marco. Naples, about i 7 ro.

OBICI, Bartolomeo. Verona, about i6So. His label is, "Bartolomio Obici in Verona, I68.". (Ante 1 47.)

ODANI, Giuseppe. Naples, I 738 .

ONG 1 RO, Ignazio. Venice, about 1780.

ORLANDELLI, Paolo. Codogno, I 7 -.

ORTEGA. Madrid, IS40. The Spanish maker and repairer through whom Luigi Tarisio obtained the famous Stradivari violoncello of 1725 , which was exhibited by Monsieur Gallay at South Kensington in $\mathrm{I}_{72}$ : he gave $£ 800$ for it. Ortega is believed to have worked in Italy in his youth.

PACHERELE, Pierre. Genoa and Turin. A native of Mirecourt, who worked for Pressenda, and afterwards at Nice. He died in $\mathbf{I} S_{7} \mathrm{I}$.

PAGiNI, J. B. Cremona, about I 745 .

PAGANONI, Antonio. Venice, I7-.

PANDOLFI, Antonio. Venice, i 7 I9.

PANSANI, Antonio. Venice and Rome, I 735.

PASENALI, Giacomo. I7-. A maker of mandolins.

PECCENINI, Alessandro. Bologna, about i590. A maker of lutes.

PEDR AZZI, Pietro. Bologna, I 784 .

PELIZON, Antonio. I79r. A viola d'amore maker.

PERIUS, Valero. Rome, about 1630. A maker of virginals.

PEZZARDI, or Pezard. Brescia, I 56o. A contemporary of Maggini, and very similar, though inferior : a clear varnish.

PILOSIO, Francesco. Gorizia, about I 748 .

PLANI, Igostino. Genoa, about 177 S.

PLATNER, Michel. Rome, about i749. Of the Techler school. His label is, "Michael Platner fecit Romæ anno I $747 . "$

POLIS, Luca de. Cremona, I751. 
POSTACCHINI, Andreas. Firmo, about i $8 \geq 0$.

POSTIGliONE, Vincenzo. Naples. He was living recently.

PRED A, Antonio. I maker of mandolins.

PRESBLER, Francesco. Milan, about r775. A maker of mandolins.

PRESSENDA, Gioranni Francesco. Turin. Jiorn 1777 , died i $55+$. He was a pupil of Storioni, and worked at Alba, Carmagnola, and Turin. Many of his violins are of the Stradivari pattern. He made a large number of violins of excellent quality, with rarnish of a reddish-brown colour: he has of late years attained a high reputation in this country; and a considerable number of his violins have been imported to meet the demand, but absurdly high prices are often asked for them, far above their real value.

RAFFAELE, Fidrini. A modern maker, recently working in Venice: he has made some excellent violins of Stradivari model.

RAILICH, Giovanni. Padua. A label of his runs, " Giovanni Railich Lautaro in Padova," and there was a fine guitar in the Vienna Exhibition of $1 \$_{92}$ with the label, "Pietro Reilich fecit in Padua," so there would appear to have been two makers at least of the name.

RANTA, Pietro. Brescia, r730.

RASURA, Vincenzo. Lugo, about $1 ;$ So.

RECHIARDINI, Giovanni. Tenice, 17 -

RESPINI, Pietro. Brescia, about $1 \$ 25$.

RICOLAZI, Lodovico. Cremona, $1720-1730$.

RINALI)I, Gioffredo. Turin. A well-known dealer and repairer, between $S_{7} \circ$ and $\mathrm{s} S S_{0}$.

RIVOLTA, Giacomo. Nlilan, iszo-1S30. 1 good modern maker.

ROCCA, (iuseppe Antonio. Turm, about i $S_{40}$

ROCHI, Sebastian. Venice, 1620. A lute-maker.

ROMANIN1, or Romarini, Antonio. Cremona, 17-.

KOMANI, Pietro. I'avia, $y_{7}-$. His name is also found as Romano, and a label is cited by Vidal, "I 7 -, P'ietro Romano in liorgo di Pavia."

ROSI.AR, Petrus. Milan, 174. A viola-maker. He used a dark red varnish.

ROSIERO, Rocco. Cremona, i 7 -

ROSSI, Innibale dei. Nilan, $1555^{-1577 . ~ A ~ f a m o u s ~}$ spinet-maker, noted for his inlaid work.

ROTA, Joannes. Cremona, 1705.

SACCHINI, Sabattino. I'esaro, 1686. 
SALVATORI, Jovanni. A maker of lutes who worked in the seventeenth century. A superb cither with his mark is in the Musée du Conservatoire, in Paris, but it is considered to be really the work of Maggini.

SANTAGIULIANA, Giacinto. Venice, about I 800 .

SARACENI, Domenico. I6-.

SARDI. Venice, 1649.

SAVANI, Giuseppe. Carpi, about i 808 .

SCARAMPELLA, Giuseppe. Born at Brescia in 1838 . Worked in Italy and in Paris, and subsequently became the partner of Luigi Castellani at Florence, where he is Conservatore of the Istituto Musicale; he has a high reputation as repairer and maker.

SEGHER, Girolamo. A workman of Nicolas Amati.

SCONVELT, Nicholas. Bologna. A celebrated lutemaker. Evelyn mentions him in his Diary, May 2 Ist, I6 45 . SCOTI, Antonio. Milan, I 740-I 750. A splendid mandora by this maker was in the Vienna Exhibition of 1892 .

SELLAS, Matteo. Venice, I630. A maker of lutes and theorbos. His label is. "Matteo Sellas alla corona Venetiis I630." He also made guitars. Three superb archilutes by him are in the Musée du Conservatoire, Paris. It would appear from a theorbo in the possession of the King of Saxony that there was a maker of this family named Giorgio, working in 1626 .

SENI, Francesco. Florence, I6-.

SENTA, Fabrizio. Turin, I 7 -.

SICILIANI, Antonio. Venice, i6-. Several instruments reputed to be by this maker were shown in Vienna in 1892 .

SICILIANI, Gio. Venice, I6-. Son of Antonio. SILVESTRI, Francesco. Verona, about isoS. A guitar-maker.

SIIIT, Giovanni. Milan. A small guitar, labelled "Giovan Smit Milano, I646," inlaid with ivory, was exhibited in Vienna in 1892.

SNEIDER, Joseph. Pavia, I 703. A pupil of Nicolo Amati. Vidal gives a label, "Joseph Sneider Papia Alumnus Nicolai Amati Cremonæe fecit, anno r $703 . "$

SOCCHI, Vincenzo. Bologna, I66I. The Musée du Conservatoire, Paris, contains a very curious pochette by this maker.

SOLIANI, Angelo. Modena, I 760-1 800.

SORSANA, Spirito. He is identical with Spirito, or Spirto, Sursano. (See ante). He worked at Cuneo about $173^{\circ}$.

SPILMAN, Dorigo. This maker appears, until 
Hajdecki's recent notice, to have been unknown. This author indicates a viol in the Modena Museum with an undated written label. The $F$ holes resemble those of Ventura Linarolli ; and the whole seems to be Venetian work.

STATLEE, Anderl. Genoa, I514. Probably a native of the Tyrol.

STEFFANINI, Carlo. Mantua, I7-. A maker of mandolins.

STREGNER, or Stregher, or Steger, Magno. Venice, I61.4. A maker of mandoras, lutes, and theorbos.

TACHINARDI, Cremona, i6-.

TAIOLINI. Modena, 17-.

TANIGARDI, Giorgio. Rome, about I 730. His label is, "Giorgio Tanigardi fecit Romæ 17 -"

TASSINI, Bartolomeo. Venice, I 754. A maker of the Testore school.

TAUS, Andrea. Sienna, 1621. He made lutes and theorbos.

TEDESCO, Leopolio. Rome, 1658 . A pupil of Nicolo Amati, whose works he copied.

TERNAGANINI, Pietro. Modena, 1755.

TIEFFENBR ÜCKER, Magno, Vendelino, and Leonardo. Venice, 15-. These celebrated lute-makers worked in Venice until about 1612, (see ante, Duiffoprugcar), and seem to have been connected with Gaspard Duiffoprugcar. The inscriptions in and descriptions of the instruments exhibited in Vienna in 1892 , taken from the original catalogues, may well be collected here, followed by those of their most celebrated pupil, Vendelino Tenere.

(a) Chitarrone, "Magno Dieffopruchar Venetia, I606," rosewood inlaid with ivory. (G. Donaldson.)

(b) Lira da braccio, "Gaspard Duiffopruggar Bononiensis anno I 5 5," with seven strings. (Mag. Aud. Hajdecki, Mostar.)

(c) Chitarrone or Roman theorbo, "Magno J)uiffopruchar a Venetia," with twelve strings and eight sympathetic strings. (The Archduke Franz leerdinand of Austria.)

(d) Lute, "Nagno Dieffopruchar a Venctia, 162I." (Royal Academy of Music, Berlin.)

(e) Mandola, "Nagnus Dieffenbruger, 1621." (Royal Academy of Music, Berlin.)

(f) Archlute, "Magno Tieffoprucar a Venetia, 160\%." Nineteen principal strings and four sympathetic strings. (Prince Moritz Lobkowitz.) 
$(g)$ Theorbo, "Magno Tieffoprucar a Venetia, I6 1о." Fourteen principal strings and ten sympathetic strings. (King of Saxony.)

(h) Iyra da gamba, "In Padoa Vendelinus Tieffenbrüker," also inscribed on the head in ink, "Vendelinus Tieffenbrüker F. in Padoua." Sixteen principal strings and fifteen sympathetic strings. (Archduke Franz Ferdinand of Austria.)

(i) Archlute, with twenty-four strings. "In Padova Wendelio Venere de Leonardo Tiefembrucker, I587." Repaired in $I_{3} I$ by Martin Stoss, of Vienna. (Gesellschaft der Musik-freunde, Vienna.)

(j) Theorbo, "161 I Padova Vvendelio Venere." Twelve principal and eight sympathetic strings. (Archduke Franz Ferdinand of Austria.)

(k) Lute, "Padova Vvendelio Venere de Leonardo Tiefembrücker I 58z." (Archduke Franz.)

(l) Lute, "Vvendelio Venere." A small instrument with nine strings. (Archduke Franz.)

(m) Harp-cither, "Padova Vvendelio Venere de Leonardo Tiefenbrücker." Fifteen strings, and fifteen on the left side, with twenty on the opposite side, upon a kind of harp-frame. (Archduke Franz.)

(n) Theorbo. "Benn Dellio Wenere in Padua I622." (Gesellschaft der Musik-freunde, Vienna.)

TIRLER, Carlo. Bologna, I 7 -

TODINI, Michele. Rome, I675. The author of "Dichiaratione della galleria armonica eretta in Roma" (Rome, 1676 ). This maker is credited, curiously enough, with the invention of the contra-bass, but the modern method of stringing the instrument may perhaps be attributed to him with justice.

TOPPANI, Angelo. Rome, about I 740. He copied Techler.

TORELLI. Verona, $16-$ -

TORTOBELLO. Rome, I6-.

TRAPANI, Raffaele. He worked at Naples in the early part of the present century, and made good instruments.

TRINELLI. Villalunga.

TRUNCO. Cremona, 1660.

UGAR, Crescenzio. Rome, i 700.

UNGARINI, Antonio. Fabriano, I 7 -

URBINAS, Augustinus Citarcedus. A cither-maker, about I590. Baron Nathaniel von Rothschild possesses a cither reputed to be by this maker. 
UNTERDORBEN, Marx. Venice, about If20. Alutemaker. This is the name found on a label in the lute discovered at the castle of Eisenberg.

YANDEILI, Gioranni. Bologna, about $1800-1 \$_{3} \circ$.

VAROTTI, Giovanni. Bologna, about i $S_{15}$.

VENERE, Padua, I534. A lute-maker. Thure was a Vendelino Venere, a famous Venctian lute-maker, in the sixteenth century. Vidal gives a label found in a cither, "In Padova Undelio Venere de Lconardo Tiefenbrucker, I 534 T. S." 'This resembles somewhat that in the lute exhibited in Tienna in $1 S_{92}$, "Padova Trendelio Tenere de I conardo Tiefembrucker, I 58 s." (See Tieffenbrücker, ante.) The precise relationship, said by one writer, Hajdecki, to have existed between the Tieffenbrücker and Tendelino Venere has not been established so far.

TENETO, Urendelio. Padua, I 609. A lute-maker.

TENZI, Andrea. Florence, 16-.

VERI.E, Francesco. Padua. The latter part of the serenteenth century.

VINACCIA, Antonio. Naples, iz66-1774. A lutemaker.

VINACCIA, Vincenzo, Gennaro, and Gaetano. Three sons of Antonio; they made zithers and mandolins.

VINACCIA, Pasquale. Naples. The son of Gactano, and the most famous mandolin-maker of this century. He was the first to use steel strings. He was born in I 806 , and worked till about $\mathrm{I} S S_{3}$.

VINCENZI, Luigi. Carpi, about 1770.

VIR, Hicronymus. Brescia. Tidal gives a label of his of much apparent antiquity, "Hicronimus di vir in Bresa." M. Vidal revived the theory that this maker worked in Bresa, in Silesia.

VIRAPI, Girolamo, Brescia, I 523. A lute-maker.

VITOR, De. Brescia. I 7 to. A follower of Maggini.

VIVOLI, Giovanni. Florence, about 16 fo.

VOBOAM, Alexandre. A maker of guitars; he appears to have worked late in the seventeenth century, first in ]taly, then in Paris. A richly ornamented guitar by him is in the Muséc du Conservatoire, laris. (No. I $6 y$.)

WACINER, Joseph. Constance, 1773.

WENGER. Padua. A lute-maker: he rorked about 1622 .

7ANFI, Giacomo. Modena, about $1760-1820$.

\% ANOII, Giacomo. Padua, т 7 -

CANOII, Giambattista. Verona, 1710-1730. 'This 
maker is stated to have worked also at Padua. He used a yellow varnish of a deep shade.

ZANOTTI, Antonio. Mantua, I 734 .

ZANOTTI, Giuseppe. Piacenza, 1 7 -

ZANURE, Pietro. Brescia, I509. Mr. G. H. M. Muntz exhibited in the South Kensington Exhibition of I 872 a curious instrument of the violin family by this maker; it was nearly as small as a pochette. He made viols. His label was, "Pietro Zanure, Brescia, $1509 . "$

ZENATTO, Pietro. Treviso, about I630.

ZIMBELMANN, Filippo. Florence, I660.

ZUCCHERO, Federigo. I5-. He was a celebrated maker of inlaid and painted work, and is also known to have made spinets.

Note.-For full description of many of the above-mentioned makers, see Vidal's "Les Instruments à archet," Paris, Claye, I $\$ 76$; and also De Piccolellis' "Liutai antichi e moderni," Florence. Le Monnier, I885. 


\section{INDEX OF NAMES.}

\begin{tabular}{|c|c|c|c|c|c|c|c|c|c|}
\hline & & & & $\mathrm{AGE}$ & & & & & Arie \\
\hline & A & & & & Barbieri... & $\cdots$ & $\cdots$ & & 25 \\
\hline Abbati ... & $\ldots$ & $\ldots$ & .. & 76 & Barnia ... & $\ldots$ & $\ldots$ & $\ldots$ & 77 \\
\hline Acevo ... & $\ldots$ & .. & $\ldots$ & is & Barzellini & $\ldots$ & $\ldots$ & $\ldots$ & 25 \\
\hline Adani ... & $\ldots$ & $\ldots$ & $\ldots$ & 76 & Bassiano & $\ldots$ & $\ldots$ & $\ldots$ & 77 \\
\hline Aglio $\ldots$ & $\ldots$ & .. & $\ldots$ & 76 & Basso ... & $\ldots$ & $\ldots$ & $\ldots$ & 77 \\
\hline Albanesi & $\ldots$ & $\ldots$ & $\cdots$ & IS & Bastogi ... & $\ldots$ & $\ldots$ & $\ldots$ & 77 \\
\hline Albani, Ma & hias & $\ldots$ & $\ldots$ & IS & Battista... & $\ldots$ & $\ldots$ & $\ldots$ & 77 \\
\hline ,, Mic & & $\ldots$ & $\ldots$ & 19 & liechardini & $\ldots$ & $\ldots$ & $\ldots$ & 77 \\
\hline $\mathrm{Pao}$ & $\ldots$ & $\ldots$ & $\ldots$ & 19 & Jelami ... & $\ldots$ & $\ldots$ & $\ldots$ & 77 \\
\hline Pau & ... & $\ldots$ & $\cdots$ & 19 & Bellone ... & $\ldots$ & $\ldots$ & $\ldots$ & 77 \\
\hline Sig & $r \ldots$ & $\ldots$ & $\cdots$ & I9 & bellosio... & $\ldots$ & $\ldots$ & $\ldots$ & 25 \\
\hline Alberti ... & $\ldots$ & $\ldots$ & $\ldots$ & 76 & Relviglieri & $\ldots$ & $\ldots$ & $\ldots$ & 77 \\
\hline Alberto ... & $\ldots$ & $\ldots$ & $\ldots$ & 76 & Benedicti. & $\ldots$ & $\ldots$ & $\ldots$ & 25 \\
\hline Altric $\ldots$ & ... & ... & ... & 7 & liente ... & $\ldots$ & $\ldots$ & $\ldots$ & 25 \\
\hline Alessandro & $\ldots$ & $\ldots$ & $\ldots$ & 76 & Berati ... & $\ldots$ & $\ldots$ & $\ldots$ & 77 \\
\hline Aletzie ... & $\ldots$ & $\ldots$ & $\cdots$ & I9 & Beretta ... & $\ldots$ & $\ldots$ & $\ldots$ & 77 \\
\hline Alrani ... & $\ldots$ & $\ldots$ & $\ldots$ & 19 & Beriot, de & $\ldots$ & $\ldots$ & $\ldots$ & 5 \\
\hline Amati, And & & $\ldots$ & 19 & 20 & Jergonzi, Car & & .. & & 25 \\
\hline Ant & & $\ldots$ & $\ldots$ & 20 & Fral & ncesco & $\ldots$ & $\ldots$ & 25 \\
\hline Hier & nymus & .. & ... & 20 & Nico & & $\ldots$ & $\ldots$ & 26 \\
\hline, & & he you & ger & 23 & Mic & hel A & gelo & $\ldots$ & 26 \\
\hline $\mathrm{Nicc}$ & is... & $\ldots$ & 13 , & 22 & Zosi & imo & $\ldots$ & $\ldots$ & 27 \\
\hline Ambrogi & $\ldots$ & $\ldots$ & $\ldots$ & 24 & Bertasio... & $\ldots$ & $\ldots$ & $\ldots$ & 77 \\
\hline Ambrosi & $\ldots$ & $\ldots$ & $\ldots$ & 76 & lerti $\ldots$ & $\ldots$ & $\ldots$ & $\ldots$ & 77 \\
\hline Ambrosio & $\ldots$ & $\ldots$ & $\ldots$ & 76 & Jianchi ... & $\ldots$ & $\ldots$ & $\ldots$ & 77 \\
\hline Andreas & $\ldots$ & $\ldots$ & $\ldots$ & $7^{6}$ & Boccherini & $\ldots$ & $\ldots$ & $\ldots$ & 4 \\
\hline Anselmo & $\ldots$ & $\ldots$ & $\ldots$ & 24 & Bodio $\ldots$ & .. & $\ldots$ & .. & 27 \\
\hline Antagnati & $\ldots$ & $\ldots$ & $\ldots$ & 76 & bomberghi & $\ldots$ & $\ldots$ & $\ldots$ & 77 \\
\hline Antoniazzi & $\ldots$ & $\ldots$ & $\ldots$ & $7^{6}$ & Jono & $\ldots$ & $\ldots$ & $\ldots$ & 27 \\
\hline Antonio, Il & ononic & nsis & $\cdots$ & $7^{6}$ & Bonoris ... & $\ldots$ & $\ldots$ & $\ldots$ & 77 \\
\hline 11 & iciliano & $\ldots$ & ... & 76 & liorelli ... & $\cdots$ & $\ldots$ & .. & 27 \\
\hline Antony ... & $\cdots$ & $\ldots$ & $\ldots$ & 76 & Bortoletti & $\ldots$ & $\ldots$ & .. & 77 \\
\hline Assalone & $\ldots$ & $\ldots$ & $\ldots$ & 2.4 & losi $\quad \ldots$ & $\ldots$ & $\ldots$ & $\ldots$ & 77 \\
\hline & $P$ & & & & Braglia ... & $\ldots$ & $\ldots$ & $\ldots$ & 75 \\
\hline & 15 & & & & Brandiglioni & $\cdots$ & $\cdots$ & $\ldots$ & 74 \\
\hline Bagatella, A & tonio & $\ldots$ & $\ldots$ & 24 & Branzo ... & $\ldots$ & $\ldots$ & .. & $-s$ \\
\hline & tro & $\ldots$ & ... & 24 & lirensi ... & $\ldots$ & $\ldots$ & $\ldots$ & Ts \\
\hline Jagnini ... & $\ldots$ & $\ldots$ & $\ldots$ & $7^{6}$ & Bresa $\ldots$ & $\ldots$ & $\ldots$ & $\ldots$ & 75 \\
\hline Baillot ... & $\ldots$ & $\ldots$ & $\ldots$ & 4 & Jurescian Scho & & $\ldots$ & $\ldots$ & 1 \\
\hline J'ajoni ... & $\ldots$ & $\ldots$ & $\ldots$ & 76 & liressano & $\ldots$ & $\ldots$ & $\ldots$ & $7 S$ \\
\hline Balestrieri, & ictro & $\ldots$ & $\ldots$ & 25 & Liroclii ... & $\ldots$ & $\ldots$ & $\ldots$ & 27 \\
\hline & omas & ... & $\cdots$ & 24 & burliani... & $\ldots$ & $\ldots$ & $\ldots$ & 27 \\
\hline Barlanti & $\ldots$ & $\ldots$ & $\ldots$ & 77 & lincetlenberg & $\ldots$ & $\ldots$ & $\ldots$ & $7 \mathrm{~s}$ \\
\hline
\end{tabular}




\begin{tabular}{|c|c|c|c|c|c|c|c|c|}
\hline \multirow{2}{*}{ Buggiano } & \multirow[b]{2}{*}{$\ldots$} & \multicolumn{2}{|r|}{ YAGE } & \multirow[b]{2}{*}{ Comble, de } & \multirow[b]{2}{*}{$\ldots$} & \multicolumn{3}{|c|}{ PAGE } \\
\hline & & $\cdots$ & $\ldots 7 S$ & & & $\cdots$ & .. 7 & 79 \\
\hline limonfigliuoli & $\ldots$ & .. & $\ldots 7 \mathrm{~S}$ & Contreras & ... & $\ldots$ & .. 2 & 29 \\
\hline Busan ... & $\ldots$ & $\ldots$ & $\ldots \quad 27$ & Cordano & $\ldots$ & $\ldots$ & $\ldots S$ & So \\
\hline Busetto ... & $\ldots$ & $\ldots$ & 19,27 & Cornelli .. & $\cdots$ & $\cdots$ & $\ldots S$ & So \\
\hline Iiusselero & $\cdots$ & $\cdots$ & $\ldots 78$ & Costa, della & $\ldots$ & $\ldots$ & $\ldots \quad 2$ & 29 \\
\hline & & & & Costaro ... & & $\cdots$ & $\ldots 8$ & 80 \\
\hline & $\mathrm{C}$ & & & Cremonese Sch & hool & $\cdots$ & $\cdots$ & 2 \\
\hline Cabroli ... & $\cdots$ & $\cdots$ & $\ldots 7 S$ & Cuni . ... & $\cdots$ & $\cdots$ & $\ldots$ s & So \\
\hline Caeste ... & $\ldots$ & $\ldots$ & $\begin{array}{l}\ldots \\
\ldots .\end{array}$ & Cuppin ... & $\cdots$ & $\cdots$ & .. & So \\
\hline Caesto ... & $\ldots$ & $\ldots$ & $\ldots \quad 2 S$ & & $\mathrm{D}$ & & & \\
\hline Calcagno & $\ldots$ & $\ldots$ & .. $7^{\mathrm{S}}$ & Dardelli & $\ldots$ & $\ldots$ & $\ldots 2=$ & 29 \\
\hline Calcanius & $\ldots$ & $\cdots$ & .. $2 S$ & Deconet & $\ldots$ & $\cdots$ & $\cdots$ & $\begin{array}{l}29 \\
\text { So }\end{array}$ \\
\hline Calonardi & $\ldots$ & $\ldots$ & 78 & Degani ... & $\ldots$ & $\ldots$ & $\ldots$ & So \\
\hline Calvarola & $\ldots$ & $\cdots$ & $\ldots 7 \mathrm{~S}$ & Della Corna & $\ldots$ & $\ldots$ & $\ldots$ & So \\
\hline Camile... & $\ldots$ & $\ldots$ & .. $2 S$ & Dini $\quad \ldots$ & $\cdots$ & $\ldots$ & $\ldots$ & So \\
\hline Camillo... & $\cdots$ & $\ldots$ & .. $2 S$ & Dominicelli & $\ldots$ & $\ldots$ & $\ldots 3$ & $3^{\circ}$ \\
\hline Cappa, Giachir & ino & $\ldots$ & ... $2 S$ & Dominichino & $\ldots$ & $\ldots$ & $\cdots$ & 30 \\
\hline ,, Giofrec & & $\ldots$ & ... $2 S$ & Domenicus & $\ldots$ & $\ldots$ & $\cdots$ & 20 \\
\hline, Giusep & pe & $\cdots$ & $\ldots \quad 2 S$ & Do & $\ldots$ & $\ldots$ & $\cdots$ & So \\
\hline Ofredu & & $\ldots$ & .. $2 S$ & D'Oneda & ... & .. & $\ldots$ & So \\
\hline Carboni... & $\ldots$ & .. & .. $7 \mathrm{~S}$ & Doni $\ldots$ & $\ldots$ & $\ldots$ & $\ldots$ & So \\
\hline Carcanius & $\ldots$ & $\cdots$ & $\ldots 7 S$ & sonetti & $\ldots$ & $\ldots$ & 8,44, & 57 \\
\hline Carcassi & $\ldots$ & $\ldots$ & .. $7 \mathrm{~S}$ & $a \ldots$ & $\ldots$ & $\ldots$ & $\therefore$ & So \\
\hline Carlino .. & $\cdots$ & $\cdots$ & $\ldots \quad x i$ & Duiffopruggar & $\ldots$ & ix, & iii, $\mathbf{I}$, & 30 \\
\hline Carlomordi & $\ldots$ & $\cdots$ & ... $7 \mathrm{~S}$ & Dulfenn... & $\ldots$ & $\ldots$ & ... & 30 \\
\hline Caspan ... & $\ldots$ & $\ldots$ & $\ldots 7 \mathrm{~S}$ & & & & & \\
\hline Cassanelli & $\ldots$ & $\cdots$ & $\ldots 7 \mathrm{~S}$ & & & & & \\
\hline Cassino... & $\cdots$ & $\cdots$ & .. 29 & ti $\ldots$ & $\cdots$ & $\cdots$ & $\cdots$ & $3^{\mathrm{I}}$ \\
\hline Castagneri & & $\ldots$ & .. $7 S$ & ger & .. & $\ldots$ & ... & So \\
\hline Castellani, Lui & igi & $\ldots$ & ... $7 S$ & ini & $\ldots$ & $\ldots$ & $\ldots$ & So \\
\hline & etro & $\ldots$ & $\ldots 7 S$ & Evangelista & $\cdots$ & $\cdots$ & $\cdots$ & So \\
\hline Castello & $\cdots$ & $\cdots$ & ... 29 & & $\mathrm{~F}$ & & & \\
\hline Castro ... & $\cdots$ & $\cdots$ & $\begin{array}{l}\text {... } \\
29\end{array}$ & Fabricatore & $x$ & & $\ldots$ & So \\
\hline Catena ... & $\cdots$ & $\cdots$ & $\begin{array}{l}\ldots \\
\ldots . \\
\ldots\end{array}$ & Fabbris... & $\cdots$ & $\cdots$ & $\cdots$ & \\
\hline Catenar & $\cdots$ & $\cdots$ & $\cdots$ & $\begin{array}{l}\text { Faboris ... } \\
\text { Facini ... }\end{array}$ & $\cdots$ & $\cdots$ & $\cdots$ & 0 \\
\hline Cati & $\ldots$ & $\cdots$ & $\cdots$ & & $\cdots$ & $\cdots$ & $\cdots$ & So \\
\hline Cattenaro & $\cdots$ & $\cdots$ & .. 79 & Falco ... & $\cdots$ & $\cdots$ & $\cdots$ & $3 I$ \\
\hline Cavalorio & $\ldots$ & $\ldots$ & .. 79 & Farinato & $\ldots$ & $\ldots$ & $\cdots$ & $3 \mathbf{I}$ \\
\hline Celionatus & $\ldots$ & $\ldots$ & .. 29 & Fendt .. & $\ldots$ & $\ldots$ & $\ldots$ & So \\
\hline Cellini ... & $\ldots$ & $\ldots$ & .. 79 & Ferati ... & $\ldots$ & $\ldots$ & $\ldots$ & So \\
\hline Cerin $\ldots$ & $\ldots$ & $\ldots$ & .. 79 & Ferrari, Agost & tino & ... & $\ldots$ & $S_{I}$ \\
\hline Ceruti, Enrico & $\ldots$ & $\ldots$ & .. 79 & Alfon & & $\cdots$ & $\cdots$ & $S_{1}$ \\
\hline , Marco & Anto & & .. 79 & , Carlo & $\ldots$ & $\ldots$ &.. & $S_{\text {I }}$ \\
\hline Giovan & nni $\mathbf{B}$ & tista & .. 79 & Ficker ... & $\ldots$ & $\cdots$ & $\ldots$ & $3 \mathrm{I}$ \\
\hline Giusep & ope & $\ldots$ & .. 79 & Fiorini ... & $\ldots$ & $\ldots$ & $\ldots$ & $8 I$ \\
\hline Cervetto & $\ldots$ & $\ldots$ & $\ldots$ & Filano.. & $\ldots$ & $\ldots$ & $\cdots$ & $8 I$ \\
\hline Chanot ... & $\ldots$ & $\ldots x i$ & xiv, 46 & Fiorillo ... & $\ldots$ & $\ldots$ & .. & $3 I$ \\
\hline Chiarelli & $\ldots$ & $\ldots$ & .. 79 & Fiscer $\quad \ldots$ & & $\ldots$ & $\ldots$ & $3 \mathrm{I}$ \\
\hline Chiavellati & $\ldots$ & .. & .. 79 & Florentine Sch & hool & $\cdots$ & $\ldots$ & 2 \\
\hline Chiocci ... & .. & $\ldots$ & $\ldots 79$ & Florenus, Gio & vanni & $\ldots$ & $\ldots$ & $3 \mathbf{I}$ \\
\hline Christa ... & $\ldots$ & $\ldots$ & $\ldots 79$ & Guic & dante & $\ldots$ & $\ldots$ & $3 I$ \\
\hline Christophori & $\ldots$ & $\cdots$ & .. 29 & Florentus. & $\ldots$ & $\cdots$ & $\ldots$ & 31 \\
\hline Circapa ... & $\ldots$ & $\ldots$ & ... 29 & Fontanelli & $\ldots$ & $\ldots$ & ... & $S_{I}$ \\
\hline Cocco $\ldots$ & $\ldots$ & $\ldots$ & .. 79 & Fornari... & $\ldots$ & ... & ... & $S_{I}$ \\
\hline
\end{tabular}




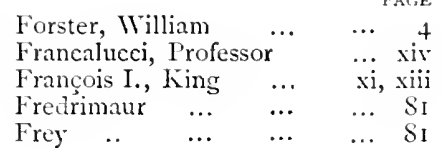

\begin{tabular}{|c|c|c|}
\hline \multicolumn{3}{|c|}{ G } \\
\hline Gabicelis & $\cdots$ & $\cdots$ \\
\hline Gabrielli & ... & $\ldots$ \\
\hline Gaetano & $\ldots$ & $\ldots$ \\
\hline Gaffino .. & $\ldots$ & $\ldots$ \\
\hline Gagliano, & Alessandro & $\ldots$ \\
\hline , , & Antonio & $\ldots$ \\
\hline , & Ferdinando & \\
\hline , , & Gennaro & $\ldots$ \\
\hline ,", & Giovanni & $\ldots$ \\
\hline , & Giuseppe & $\ldots$ \\
\hline , , & Januarius & $\ldots$ \\
\hline , & Nicolo &. \\
\hline & Raphael & $\cdots$ \\
\hline Galbani... & $\cdots$ & $\cdots$ \\
\hline Galbusera & ... & $\cdots$ \\
\hline Galerzena & $\ldots$ & $\ldots$ \\
\hline Galtani ... & $\cdots$ & $\because$ \\
\hline Garani, & lichael Ans & \\
\hline
\end{tabular}

Gaspan ... $\quad \ldots \quad \ldots$

Gattanani $\quad \ldots \quad \ldots$

Gatanari, Enrico $\quad \ldots$

‥ 31

... $3 \mathrm{I}$

‥ 32

... $S_{1}$

‥ 32

… 34

... 33

‥ 34

‥ 34

... 33

... 34

‥ 33

… 34

... $S_{I}$

... $S_{\text {I }}$

… 34

... SI

... 34

... 34

... $S_{1}$

... 34

... $S_{\mathrm{I}}$
... $S_{1}$

... $S_{\text {I }}$

‥ 35

‥ 35

... $\mathrm{S}_{2}$

... $\mathrm{S}_{2}$

... $\mathrm{S}_{2}$

... $S 2$

... $\mathrm{S}_{2}$

... 82

‥ 35

... $\mathbf{S}_{2}$

... 35

‥ 35

... 35

... $3^{6}$

... 36

... 37

... 37

a.. 36

$\begin{array}{crrrr}, & \text { Paolo } & . . & 23, & 3^{6} \\ \text { Gregori } & . . & \ldots & \ldots & 82\end{array}$

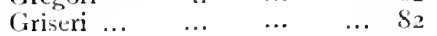

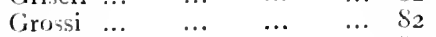

Guarmandi

Guadagnini, Antonio racie

$\begin{array}{lllll} & & & & \\ \text { andi } & . & \ldots & \ldots & \text { S2 }\end{array}$

$\begin{array}{llll}\text { Giuseppe } & \ldots & \ldots & 39\end{array}$

Guarnieri, Giuseppe Antonio del Gesi

P. $\cdots \quad \cdots \quad 4+4$

,, Pietro $\ldots$... to

G., Pietro Giovanni ... 40

$\begin{array}{lllll}\text { Guidantus } & \ldots & \ldots & \ldots & 45\end{array}$

$\begin{array}{lllll}\text { Guidomini } & \ldots & \ldots & . . & 45\end{array}$

$\begin{array}{llllll}\text { Gudio } & \ldots & \ldots & \ldots & \ldots & S_{2}\end{array}$

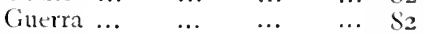

$\begin{array}{lllll}\text { Gugliemi } & \ldots & \ldots & \ldots & \$ 2\end{array}$

$\begin{array}{lllll}\text { Givillami } & \ldots & . . & \ldots & \$ 2\end{array}$

$\begin{array}{lllll}\text { Guletto } . . . ~ & \ldots & \ldots & \ldots & 45\end{array}$

$\begin{array}{lllll}\text { Gusetto... } & \ldots & \ldots & \ldots & 45\end{array}$

H

Habeneck $\quad \ldots \quad$...

Hajdecki $\quad \ldots \quad \ldots$ viii, xiv, $s_{7}$

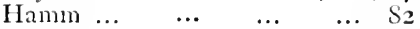

$\begin{array}{lllll}\text { Hartming } & \ldots & \ldots & \ldots & \$_{2}\end{array}$

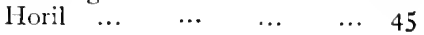

$\begin{array}{lllll} & \text { I } & & & \\ \text { Indelami } & \ldots & \ldots & \ldots & S_{2}\end{array}$

Jacobs, Henry ... $\quad \ldots \quad \ldots \quad 45$

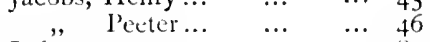

$\begin{array}{llllll}\text { Jadra } & \ldots & \ldots & \ldots & \ldots & S_{2}\end{array}$

$\begin{array}{lllll}\text { Jonnnes... } & \ldots & \ldots & \ldots & 46\end{array}$

$\begin{array}{llllll}\text { Jorio } & \ldots & \ldots & \ldots & \ldots & \mathrm{S}_{2}\end{array}$

$\begin{array}{llllll}\text { Juli } & \ldots & \ldots & \ldots & \ldots & \mathrm{S}_{2}\end{array}$

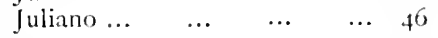

Kaiser .. $\quad \ldots \quad \ldots \quad \ldots 8_{2}$

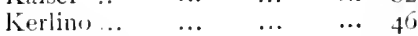

Klutz, Carl $\quad \ldots \quad$... $\quad \ldots \quad 47$

,, Egictio ... $\quad \ldots \quad$... 46

", lisirlio the younger $\quad . .44$

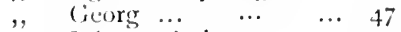

$\begin{array}{llll}\text {,, Johann (arl } & \ldots & \ldots & 47\end{array}$

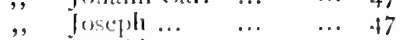

" Wathias $\quad . .6 \quad \ldots .40$

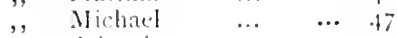

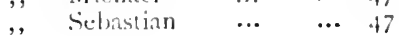




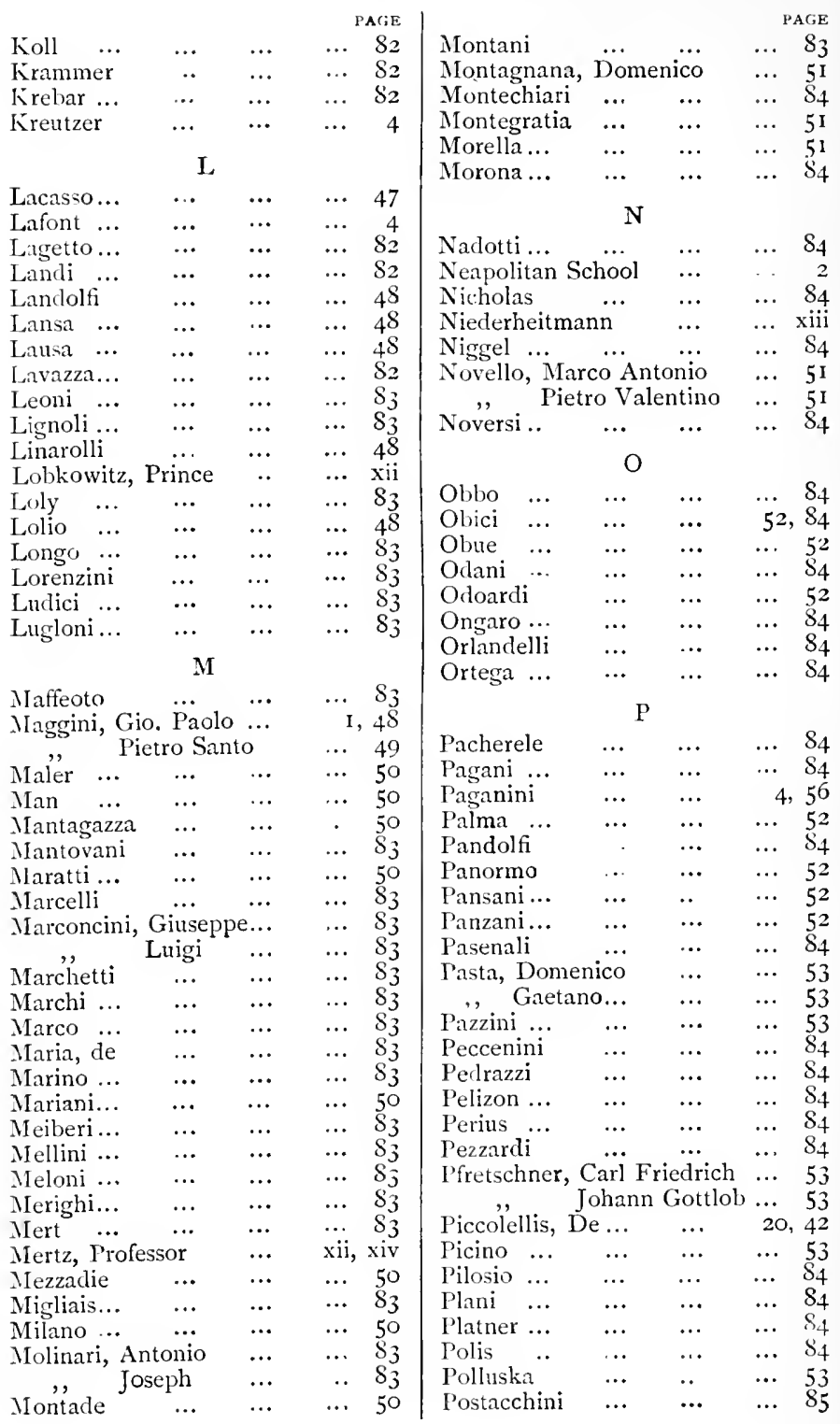




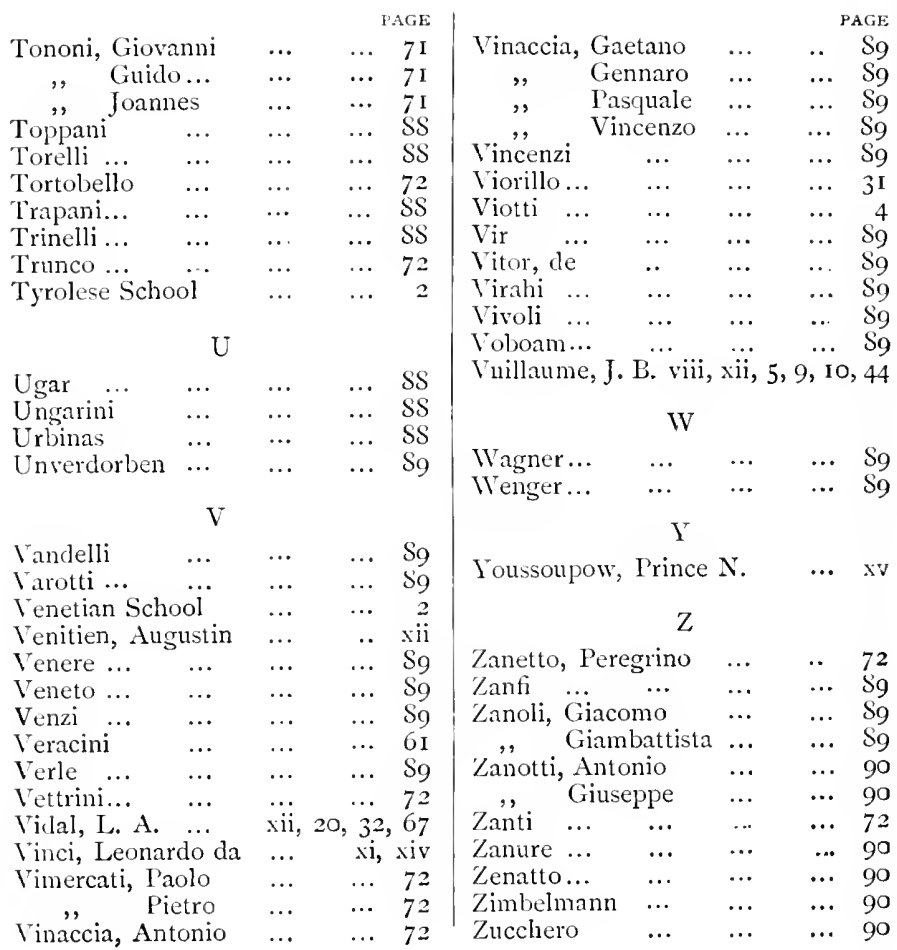





UCLA - Music Library

ML 830 N552CE 1894

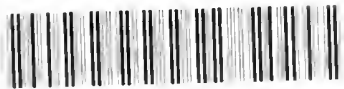

„MUSIC

LIBRARY

L 0070003728

MI

830

$\mathrm{M} 552 \mathrm{cE}$

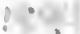

AA $000529294 \quad 1$ 
